\title{
Divining gold in seafloor polymetallic massive sulfide systems
}

\author{
Sebastian Fuchs ${ }^{1,2}$ (D) $\cdot$ Mark D. Hannington ${ }^{1,3} \cdot$ Sven Petersen $^{1}$
}

Received: 3 November 2018 / Accepted: 6 May 2019 / Published online: 29 June 2019

(C) The Author(s) 2019

\begin{abstract}
Hydrothermal fluids on the modern seafloor are important carriers of base and precious metals in a wide range of volcanic and tectonic settings. The concentrations and distribution, especially of gold and silver, in associated seafloor massive sulfide (SMS) deposits are strongly influenced by variable source rocks, fluid chemistry, and precipitation mechanisms. Compositional data of 130 SMS deposits around the world show a large range of gold and silver grades, in part reflecting strong buffering of the hydrothermal fluids by their host rocks. Geochemical reaction-path modeling shows that in most cases the investigated hydrothermal fluids are undersaturated with gold and silver, and solubilities can be orders of magnitude higher than the $\mathrm{Au}$ and $\mathrm{Ag}$ concentrations measured in the corresponding fluids. Precipitation of gold during conductive cooling of mid-ocean ridge black smoker (MOR) fluids occurs at low temperatures but can be very rapid, with $>90 \%$ of the gold deposited in the first $25^{\circ} \mathrm{C}$ of cooling below $\sim 150{ }^{\circ} \mathrm{C}$. The result is a $\mathrm{Zn}-\mathrm{Au}$ polymetallic assemblage with $\mathrm{Au}$ and $\mathrm{Ag}$ deposited at the same time together with $\mathrm{Pb}$ and sulfosalts. In ultramafic-dominated (UM) systems, the strongly reduced hydrothermal fluids promote the deposition of gold at higher temperatures and explain the correlation between gold and copper in these deposits. In this case, the lower stability of the $\mathrm{AuHS}^{\circ}$ complex at low $f \mathrm{O}_{2}$ (buffered by fayalite, magnetite, and quartz) results in gold deposition at $>250{ }^{\circ} \mathrm{C}$ with early bornite and chalcopyrite and before sphalerite and silver, producing a high-temperature $\mathrm{Cu}-\mathrm{Au}$ assemblage. In sediment-hosted (SED) systems, the much higher $\mathrm{pH}$ stabilizes $\mathrm{Au}(\mathrm{HS})_{2}{ }^{-}$and keeps gold in solution to very low temperatures, after the precipitation of chalcopyrite, sphalerite, and galena, resulting in Au-poor polymetallic sulfides and very late-stage deposition of gold, commonly with amorphous silica. In arc-related (ARC) systems, gold deposition occurs at somewhat higher temperatures than in the MOR case, in part because the fluids start with higher gold concentrations. This can be explained by probable direct magmatic contributions, and the high $\mathrm{fO}_{2}$ of the fluids, which promotes the solubility of gold at the source. During cooling, gold precipitates at about $160{ }^{\circ} \mathrm{C}$ with sphalerite, tennantite, silver, and galena, resulting in an Au-rich polymetallic sulfide assemblage. The mixing of hydrothermal fluids with seawater generally causes oxidation and eventually a decrease in the $\mathrm{pH}$ at a mixing ratio of 1:1, causing an initial increase in the solubility of gold and silver. This can delay gold deposition from aqueous species to very low temperatures. These complex systematics make prediction of $\mathrm{Au}$ and $\mathrm{Ag}$ grades difficult. However, important new data are coming to light on the actual concentrations of the precious metals in hydrothermal fluids. In particular, the input of magmatic volatiles and leaching of pre-existing gold can lead to significant increases in the Au and Ag concentrations of the venting fluids and earlier deposition. In several cases, it appears that at least part of the gold load is present as nanoparticles in suspension, allowing bulk gold concentrations that may be far in excess of liquid saturation. Boiling at the seafloor is now widely observed, even at great water depths close to the critical point of seawater. Model calculations of phase separation during boiling show the competing effects on gold solubility of $\mathrm{H}_{2}, \mathrm{H}_{2} \mathrm{~S}$, and $\mathrm{CO}_{2}$ partitioning into the vapor, which can result in highly variable gold-to-base metal ratios in the deposits. Flashing of the vent fluids into steam at high temperatures is also commonly observed and can lead to spectacular $\mathrm{Au}$ grades, with a strong $\mathrm{Cu}-\mathrm{Au}$ association in the deepest and hottest vents.
\end{abstract}

Editorial handling: G. Beaudoin

Electronic supplementary material The online version of this article (https://doi.org/10.1007/s00126-019-00895-3) contains supplementary material, which is available to authorized users.

Sebastian Fuchs

sfuchs@geomar.de; sebastian.fuchs@bgr.de

1 GEOMAR - Helmholtz Centre for Ocean Research Kiel, Wischhofstrasse 1-3, 24148 Kiel, Germany
2 Present address: Federal Institute for Geosciences and Natural Resources, Stilleweg 2, 30655 Hanover, Germany

3 Department of Earth and Environmental Sciences, University of Ottawa, 25 Templeton, Ottawa KIN 6N5, Canada 
Keywords Gold · Silver $\cdot$ Geochemical modeling $\cdot$ Seafloor massive sulfides $\cdot$ Ore deposits $\cdot$ Trace element chemistry

\section{Introduction}

The controls on the gold enrichment in volcanogenic massive sulfide (VMS) deposits have been a persistent theme in ore deposits research for more than 30 years. A major motivation is that gold production from massive sulfide deposits accounts for a significant portion of their metal value; some deposits are world-class gold mines containing more than $100 \mathrm{t} \mathrm{Au}$ (Mercier-Langevin et al. 2011). The main geological characteristics of gold-rich VMS deposits have been extensively reviewed (Hannington et al. 1986, 1999; Hannington and Scott 1989a, b; Large et al. 1989; Large 1992; Poulsen and Hannington 1996; Sillitoe et al. 1996; Huston 2000; Dubé et al. 2007; Mercier-Langevin et al. 2011). From these studies, it is clear that highly variable amounts of Au may be found in different systems, both in terms of grade and total Au content. Some resemble hybrid VMS-epithermal systems (e.g., Eskay Creek), whereas others are characterized by alteration and/or sulfide mineral assemblages that indicate a direct magmatic contribution to the hydrothermal fluids (e.g., Boliden). Typically, when gold is present, a plausible explanation for the enrichment can be advanced. However, it is important to note that many deposits contain virtually no detectable gold at all, the absence of which is often difficult to explain when similar deposits nearby are well-endowed. Highly variable grades are the expression of the intricate system dynamics affecting the hydrothermal fluids, including conductive cooling, subsurface entrainment of seawater, leaching of preexisting $\mathrm{Au}$, phase separation, and inputs of magmatic volatiles (Hannington et al. 1995, 2017). Several or even all of these factors may contribute to gold enrichment at a variety of different scales, from an individual sulfide chimney to an entire VMS district.

Since the discovery of the first hydrothermal vents at the Galapagos Rift in 1977 (Lonsdale 1977) and black smokers at East Pacific Rise a few years later (Francheteau et al. 1979; Spiess et al. 1980; Hekinian et al. 1983), more than 600 active and inactive hydrothermal sites have been found in the world's oceans. More than 300 are associated with significant base metal-sulfide mineralization (Baker and German 2004; Hannington et al. 2005, 2010; Beaulieu et al. 2013; Monecke et al. 2016). Bulk analyses of recovered massive sulfide samples $(n=3885)$ have average grades of $4.3 \mathrm{wt} \%$ $\mathrm{Cu}, 10.6 \mathrm{wt} \% \mathrm{Zn}, 0.1 \mathrm{wt} \% \mathrm{~Pb}, 1.7 \mathrm{ppm} \mathrm{Au}$, and $107 \mathrm{ppm} \mathrm{Ag}$, which are comparable to massive sulfide deposits mined on land (Franklin et al. 2005; Hannington et al. 2010). High Au and $\mathrm{Ag}$ grades have been documented in samples from deposits in a wide range of geological settings. Early studies (Hannington and Scott 1989a; Huston and Large 1989) showed that cooling of high-temperature hydrothermal fluids and mixing with seawater are fundamental controls on the precipitation of gold and associated silver. At high temperatures (e.g., $\sim 350{ }^{\circ} \mathrm{C}$ in black smoker vents), substantial amounts of the dissolved Au were thought to be carried out of the system and lost to hydrothermal plumes (Hannington and Scott 1989a; Herzig and Hannington 1995). Initially, the strong $\mathrm{Cu}-\mathrm{Au}$ association observed in many ancient massive sulfide deposits (Huston et al. 2011) was not recognized in black smokers. However, continuing efforts to document different types of seafloor hydrothermal have provided new clues to the causes of $\mathrm{Au}$ enrichment, with important implications for exploration in ancient VMS systems.

In this study, we explore how different source rocks and buffer assemblages can account for significant variability in the geochemical behavior of $\mathrm{Au}$ in various settings. Geochemical reaction-path modeling is used to assess Au enrichment in (i) basalt-hosted systems at mid-ocean ridges, (ii) ultramafic rock-hosted systems, (iii) sediment-dominated systems, and (iv) arc-related systems including at intraoceanic arc volcanoes and transitional arcs and back-arc spreading centers. We compare a comprehensive geochemical dataset of seafloor massive sulfide (SMS) deposits around the world with the physicochemical conditions of hydrothermal transport and deposition of precious metals in each of these settings.

\section{Gold and silver concentrations in seafloor massive sulfides deposits}

Median grades of $\mathrm{Au}$ and $\mathrm{Ag}$ in 130 occurrences of seafloor massive sulfides worldwide are listed in Table 1. The database derives from an extensive compilation originally published in 2004 (Hannington et al. 2004) and updated with results from 57 additional publications (references cited in ESM 1). The locations of the deposits and the ranges of $\mathrm{Au}$ and $\mathrm{Ag}$ grades are shown in Fig. 1a, b. The different types of deposits are classified according to their volcanic substrates, including mid-ocean ridge basalt, ultramafic intrusive rocks, and more evolved volcanic suites in both oceanic and continental crust. These differences have been reviewed comprehensively in Hannington et al. (2005) and are summarized below. The range of $\mathrm{Au}$ and $\mathrm{Ag}$ concentrations in the deposits (Fig. 2) reflects a number of different factors, but it is clear that the geological setting and volcanic substrate are major underlying controls in all cases.

Basalt-hosted deposits on the mid-ocean ridges are mainly discriminated on the basis of spreading rate, which varies in response to regional tectonic stresses and rates of magma supply. Fast-spreading ridges (full spreading rates of 6-14 cm/ 
Table 1 Details of seafloor massive sulfide deposits shown in Fig. 1

\begin{tabular}{|c|c|c|c|c|c|c|c|c|c|c|c|}
\hline No & Deposit & Region & Depth (m) & Spreading rate $^{1}$ & Area $\left(\mathrm{m}^{2}\right)^{2}$ & ${ }^{2}$ Vent temp. $\left({ }^{\circ} \mathrm{C}\right)$ & $\mathrm{pH}\left(\right.$ at $\left.25^{\circ} \mathrm{C}\right)$ & $\mathrm{Au}(\mathrm{g} / \mathrm{t})$ & $\mathrm{N}(\mathrm{Au})$ & $\mathrm{Ag}(\mathrm{g} / \mathrm{t})$ & $\mathrm{N}(\mathbf{A g})$ \\
\hline \multicolumn{12}{|c|}{ Basalt-hosted mid-ocean ridge (MOR) } \\
\hline 1 & Lokis Castle & Mohns Ridge & 2320 & ultra-slow & & 317 & 5.5 & 0.17 & 22 & 2.55 & 22 \\
\hline 2 & Sonne, Meso Field & Central Indian Ridge & 2845 & intermediate & 50000 & & & 0.85 & 34 & 33 & 37 \\
\hline 3 & Edmond Field & Central Indian Ridge & 3290 & intermediate & 3000 & 382 & 3.0 & 1.2 & 32 & 47 & 35 \\
\hline 4 & Mount Jourdanne & Southwest Indian Ridge & 2940 & ultra-slow & $<100$ & & & 3.4 & 9 & 232 & 9 \\
\hline 5 & Longqi Field (SWIR 49 $39^{\prime} E$ ) & Southwest Indian Ridge & 2750 & ultra-slow & & 379 & 3.2 & 2.1 & 36 & 63 & 36 \\
\hline 6 & Yuhuang & Southwest Indian Ridge & 1500 & ultra-slow & & & & 0.78 & 18 & 34 & 18 \\
\hline 7 & South Explorer Ridge & Juan de Fuca Ridge & 1850 & intermediate & 5000 & 311 & 3.9 & 0.38 & 51 & 52 & 49 \\
\hline 8 & High Rise Vent Field & Juan de Fuca Ridge (Endeavour) & 2150 & intermediate & 3000 & 352 & & 0.26 & 49 & 50 & 50 \\
\hline 9 & Main Vent Field & Juan de Fuca Ridge (Endeavour) & 2150 & intermediate & 5000 & 402 & 4.2 & 0.06 & 82 & 18 & 49 \\
\hline 10 & Mothra Vent Field & Juan de Fuca Ridge (Endeavour) & 2270 & intermediate & 5000 & 319 & & 0.10 & 203 & 56 & 203 \\
\hline 11 & Co-Axial Segment & Juan de Fuca Ridge & 2055 & intermediate & $<100$ & 294 & 4.7 & 0.93 & 6 & 57 & 6 \\
\hline 12 & CASM Vent Field & Juan de Fuca Ridge (Axial Smt.) & 1580 & intermediate & $<100$ & & & 3.7 & 31 & 166 & 32 \\
\hline 13 & ASHES Vent Field & Juan de Fuca Ridge (Axial Smt.) & 1544 & intermediate & $<100$ & 328 & 3.5 & 1.5 & 92 & 120 & 85 \\
\hline 14 & Northern Cleft & Juan de Fuca Ridge (Northern Cleft) & 2245 & intermediate & $<100$ & & & 0.26 & 29 & 150 & 29 \\
\hline 15 & Southern Cleft & Juan de Fuca Ridge (Southern Cleft) & 2200 & intermediate & $<100$ & 342 & 3.0 & 0.10 & 3 & 278 & 12 \\
\hline 16 & $21^{\circ} \mathrm{N}, \mathrm{EPR}$ (Rise) & East Pacific Rise & 2620 & intermediate & $<100$ & 355 & & 0.10 & 24 & 35 & 46 \\
\hline 17 & $13^{\circ} \mathrm{N}, \mathrm{EPR}$ & East Pacific Rise & 2650 & fast & 5000 & & & 0.35 & 74 & 44 & 87 \\
\hline 18 & $11^{\circ} 30^{\prime} \mathrm{N}, \mathrm{EPR}$ & East Pacific Rise & 2500 & fast & $<100$ & & & 0.13 & 18 & 6.0 & 18 \\
\hline 19 & $11^{\circ} \mathrm{N}$, EPR & East Pacific Rise & 2525 & fast & $<100$ & 347 & & 0.12 & 11 & 24 & 17 \\
\hline 20 & Beebe (Piccard) Vent Field & Cayman Trough & 4960 & ultra-slow & & 398 & 3.1 & 6.9 & 29 & 50 & 29 \\
\hline 21 & $89^{\circ} \mathrm{W}$ (Site SO208) & Galapagos Rift & 1720 & intermediate & & & & 2.0 & 9 & 92 & 9 \\
\hline 22 & Site $A\left(85^{\circ} 51^{\prime} \mathrm{W}\right)$ & Galapagos Rift & $2540-2610$ & intermediate & & & & 0.11 & 42 & 17 & 44 \\
\hline 23 & Site $B\left(85^{\circ} 55^{\prime} \mathrm{W}\right)$ & Galapagos Rift & 2580 & intermediate & 30000 & & & 0.34 & 49 & 32 & 49 \\
\hline 24 & Site $F\left(85^{\circ} 58^{\prime} \mathrm{W}\right)$ & Galapagos Rift & 2525 & intermediate & & & & 0.26 & 3 & 28 & 3 \\
\hline 25 & $07^{\circ} 24^{\prime} \mathrm{S}$, EPR & East Pacific Rise & 2735 & ultra-fast & $<100$ & 340 & & 0.06 & 13 & 20 & 14 \\
\hline 26 & $16^{\circ} 43^{\prime}$ 'S, EPR & East Pacific Rise & 2600 & ultra-fast & $<100$ & & & 0.24 & 19 & 44 & 19 \\
\hline 27 & $18^{\circ} 25^{\prime}$ S, EPR & East Pacific Rise & 2630 & ultra-fast & $<100$ & 382 & 3.1 & 0.56 & 14 & 163 & 35 \\
\hline 28 & $21^{\circ} 30^{\prime} \mathrm{S}$, EPR & East Pacific Rise & $2800-2830$ & ultra-fast & $<100$ & 354 & & 0.46 & 12 & 46 & 28 \\
\hline 29 & $23^{\circ} 32^{\prime} \mathrm{S}$, EPR & East Pacific Rise & 2601 & ultra-fast & & 297 & & 0.03 & 7 & 27 & 7 \\
\hline 30 & $31^{\circ} 09^{\prime} \mathrm{S}$ (Nolan's Nook), EPR & East Pacific Rise & 2330 & ultra-fast & & 378 & & 0.01 & 3 & 13 & 3 \\
\hline 31 & $31^{\circ} 52^{\prime} \mathrm{S}$ (Saguaro Vent), EPR & East Pacific Rise & 2320 & ultra-fast & & 370 & & 0.12 & 3 & 47 & 3 \\
\hline 32 & $37^{\circ} 40^{\prime}$ 'S PAR & Pacific-Antarctic Ridge & 2230 & fast & & & & 1.08 & 2 & 301 & 2 \\
\hline 33 & $37^{\circ} 48^{\prime}$ S PAR & Pacific-Antarctic Ridge & 2230 & fast & & 326 & & 0.56 & 36 & 37 & 36 \\
\hline 34 & Aurora & Gakkel Ridge & 4000 & ultra-slow & & & & 2.2 & 11 & 4.0 & 11 \\
\hline 35 & Trollvegen & Mohns Ridge & 550 & ultra-slow & & 260 & & 0.62 & 5 & 62 & 5 \\
\hline 36 & Soria Moria & Mohns Ridge & 645 & ultra-slow & & 270 & & 1.5 & 7 & 79 & 7 \\
\hline 37 & Menez Gwen & Mid-Atlantic Ridge (Azores) & 840 & ultra-slow & & 299 & 4.2 & 0.10 & 12 & 20 & 15 \\
\hline 38 & Lucky Strike & Mid-Atlantic Ridge (Azores) & $1730-1618$ & ultra-slow & 3000 & 333 & 3.6 & -- & -- & 117 & 3 \\
\hline 39 & Broken Spur & Mid-Atlantic Ridge & $3110-3080$ & slow & 5000 & 362 & & 0.56 & 14 & 20 & 28 \\
\hline 40 & Alvin Zone (TAG) & Mid-Atlantic Ridge & $3540-3600$ & slow & 100000 & & & 0.90 & 4 & 21 & 4 \\
\hline 41 & TAG, Active Mound & Mid-Atlantic Ridge & 3670 & slow & 30000 & 369 & 3.0 & 0.41 & 211 & 5.0 & 268 \\
\hline 42 & MIR Zone (TAG) & Mid-Atlantic Ridge & $3540-3575$ & slow & 50000 & & & 1.6 & 54 & 38 & 54 \\
\hline 43 & Snakepit & Mid-Atlantic Ridge & $3465-3512$ & slow & 15000 & 366 & 3.7 & 0.95 & 99 & 36 & 97 \\
\hline 44 & Krasnov & Mid-Atlantic Ridge & $3700-3750$ & slow & 150000 & & & 1.8 & 9 & 15 & 9 \\
\hline 45 & Semyenov-4 & Mid-Atlantic Ridge & $2580-2950$ & slow & & & & 0.53 & 78 & 4.6 & 78 \\
\hline 46 & Red Lion & Mid-Atlantic Ridge & 3050 & slow & & 348 & 3.8 & 0.7 & 9 & 59 & 9 \\
\hline 47 & Comfortless Cove & Mid-Atlantic Ridge & 2996 & slow & & 399 & 2.4 & 0.4 & 12 & 31 & 12 \\
\hline 48 & Turtle Pits & Mid-Atlantic Ridge & 2990 & slow & 5000 & 407 & 2.4 & 0.2 & 52 & 12 & 52 \\
\hline
\end{tabular}

year) occur in relatively thin oceanic crust and are characterized by abundant volcanic eruptions; intermediate-rate (4$6 \mathrm{~cm} /$ year) and slow-spreading $(2-4 \mathrm{~cm} /$ year) ridges occur in relatively thick crust and are characterized by only intermittent volcanism between long periods of tectonic extension and/or intrusive activity. Most ridges are dominated by normal mid-ocean ridge basalt (N-MORB), but some intermediate spreading centers have more evolved magma compositions (ferrobasalt and andesite), which may be related to magma mixing, fractional crystallization at shallow to intermediate crustal depths, or assimilation of hydrated crust (Perfit et al. 1999). At slow-spreading ridges, which have a low melt supply, the crust is composed mainly of gabbroic intrusions, and locally, ultramafic rocks are exposed. These differences in volcanic substrate have a subtle but important influence on the compositions of the hydrothermal fluids and the behavior of Au. The presence of sediments also has a large effect on the compositions of the vent fluids.

Subduction-related hydrothermal systems are of two main types: vents found in the summit calderas of submarine volcanoes at the volcanic fronts of arcs and those associated with arc rifting and back-arc spreading. The volcanic arcs include both intraoceanic and "transitional" or island arcs. Intraoceanic arcs are developed mainly on a basement of oceanic crust, and the volcanism is typically basaltic, becoming more andesitic and calc-alkaline as the arc crust thickens. The magmas are mainly products of partial melting caused by the addition of $\mathrm{H}_{2} \mathrm{O}$ and other volatiles to the subarc mantle from subducted sediments and hydrated oceanic crust. Typical island-arc basalt (IAB) differs from MORB by having higher $\mathrm{H}_{2} \mathrm{O}$ and $\mathrm{CO}_{2}$ contents, higher $\mathrm{Fe}_{2} \mathrm{O}_{3} / \mathrm{FeO}$, and enrichments in certain elements, notably large-ion-lithophile elements, such as $\mathrm{Ca}, \mathrm{Ba}, \mathrm{Cs}, \mathrm{K}, \mathrm{Rb}$, and $\mathrm{Sr}$. Vent fluid compositions are broadly similar to those at mid-ocean ridges, but the arc magmas supply a number of different components to the hydrothermal fluids, including possibly the precious metals. Transitional arcs are developed on older arc crust and, in some cases, on young continental crust, which can also provide additional metals. Felsic volcanic rocks are common in these settings, resulting from partial melting and/or fractional crystallization of magmas trapped in the thickened arc crust or continental crust. The majority of the known high-temperature vents in the western Pacific occur at intraoceanic back-arc spreading centers, which develop after a prolonged episode of arc rifting, caused by trenchward migration and sinking of the subducting plate, followed by passive upwelling of mantle material. Back-arc basin basalts, or 
Table 1 (continued)

\begin{tabular}{|c|c|c|c|c|c|c|c|c|c|c|c|}
\hline \multirow{3}{*}{\multicolumn{2}{|c|}{$\begin{array}{l}\text { No } \quad \text { Deposit } \\
\text { Ultramafic rock-hosted mid-ocean ridge (UM) } \\
49 \quad \text { Kairei }\end{array}$}} & Region & Depth (m) & Spreading rate ${ }^{1}$ & Area $\left(\mathrm{m}^{2}\right)$ & Vent temp. $\left({ }^{\circ} \mathrm{C}\right)$ & $\mathrm{pH}$ (at $25^{\circ} \mathrm{C}$ & $\mathrm{Au}(\mathrm{g} / \mathrm{t})$ & $N(\mathrm{Au})$ & Ag $(g / t)$ & $N(\mathrm{Ag})$ \\
\hline & & & & & & & & & & & \\
\hline & & Central Indian Ridge & 2450 & intermediate & 3000 & 369 & 3.0 & 0.85 & 23 & 15 & 23 \\
\hline 50 & & Mid-Atlantic Ridge & $2260-2310$ & slow & 30000 & 370 & 2.7 & 2.0 & 43 & 46 & 42 \\
\hline 51 & Logatchev & Mid-Atlantic Ridge & $2940-3040$ & slow & 5000 & 370 & 3.3 & 6.3 & 152 & 31 & 139 \\
\hline 52 & Semyenov-1 & Mid-Atlantic Ridge & $2570-2620$ & slow & & & & 1.3 & 17 & 13 & 17 \\
\hline 53 & Semyenov-2 & $\begin{array}{l}\text { Mid-Altantic Ridge } \\
\text { Mididtantic Ridge }\end{array}$ & $\begin{array}{l}2420 \\
2200-2500\end{array}$ & $\begin{array}{c}\text { slow } \\
\text { slow }\end{array}$ & 300000 & 317 & & 1.2 & 41 & 27 & 41 \\
\hline $\begin{array}{l}54 \\
55\end{array}$ & $\begin{array}{l}\text { Semyenov-3 } \\
\text { Semyenov-5 }\end{array}$ & $\begin{array}{l}\text { Midd-Atantici Ridge } \\
\text { Mid-Atlantic Ridge }\end{array}$ & $\begin{array}{l}2200-2500 \\
2200-2500\end{array}$ & $\begin{array}{l}\text { slow } \\
\text { ssow }\end{array}$ & & & & $\begin{array}{l}0.33 \\
0.85\end{array}$ & 10 & 7.9 & 10 \\
\hline 56 & $\begin{array}{l}\text { Semyenov-5 } \\
\text { Irinovskoe }\end{array}$ & $\begin{array}{l}\text { Milu-Alannick Kage } \\
\text { Mid-Atlantic Ridge }\end{array}$ & 2770 & $\begin{array}{l}\text { Slow } \\
\text { slow }\end{array}$ & & 364 & & 0.85 & 13 & 22 & $\begin{array}{l}12 \\
13\end{array}$ \\
\hline 57 & Ashadze-1 & Mid-Atlantic Ridge & 4088 & 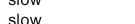 & 50000 & 374 & 31 & 26 & 104 & 列 12 & 104 \\
\hline 58 & Ashadze-2 & Mid-Atlantic Ridge & 3260 & slow & 50000 & 296 & 4.1 & 11 & 23 & 8 & 23 \\
\hline 59 & Nibelungen & Mid-Atlantic Ridge & 2905 & slow & $<100$ & 372 & 2.9 & 1.0 & 9 & 56 & 9 \\
\hline & covered basalt-hosted mid-ocean & nridge (SED) & & & & & & & & & \\
\hline 60 & Middle Valley & Juan de Fuca Ridge & 2450 & intermediate & 50000 & 276 & 5.5 & 0.05 & 62 & 2.0 & 183 \\
\hline 61 & Escanaba Trough & Gorda Ridge & 3300 & intermediate & 1000 & 217 & 5.4 & 0.74 & 35 & 60 & 35 \\
\hline 62 & Northern Trough & Gulf of California (Guaymas Basin) & 2000 & intermediate & 15000 & & & 0.07 & 10 & 2.5 & 10 \\
\hline & Southern Trough & Gulf of California (Guaymas Basin) & 2000 & intermediate & & 359 & 5.9 & 0.12 & 10 & 17 & 23 \\
\hline & $r(1-A R C)$ & & & & & & & & & & \\
\hline 64 & Palinuro Volcanic Complex & Tyrrhenian Sea & $650-1000$ & & 3000 & & & 0.31 & 56 & 90 & 56 \\
\hline 65 & Panarea Volcanic Complex & Aeolian Arc & $250-10$ & & & 135 & 4.4 & - & - & 4.2 & 5 \\
\hline & Kolombo Seamount & Hellenic Arc & 505 & & & 224 & & 7.5 & 12 & 205 & 12 \\
\hline 67 & Higashi-Aogashima & Zzu-Ogasawara Arc & 760 & & & & & 15 & & 630 & 13 \\
\hline $\begin{array}{l}68 \\
69\end{array}$ & $\begin{array}{l}\text { Myojin Knoll, Sunrise Deposit } \\
\text { Mvoiinsho Caldera }\end{array}$ & $\begin{array}{l}\text { Izu-Ogasawara Arc } \\
\text { Izu-Ogoasawara Arc }\end{array}$ & $\begin{array}{l}1237 \\
1110\end{array}$ & & 150000 & 278 & & 3.5 & $\begin{array}{c}19 \\
3\end{array}$ & ${ }_{170}^{75}$ & 19 \\
\hline 70 & $\begin{array}{l}\text { Myojinsino Caderar } \\
\text { Suiyo Seamount }\end{array}$ & Izu-Ogasawara Arc & 1370 & & 3000 & 317 & 3.5 & $\begin{array}{l}1.9 \\
43\end{array}$ & $\begin{array}{l}3 \\
36\end{array}$ & 322 & $\begin{array}{c}3 \\
38\end{array}$ \\
\hline 71 & East Diamante Mounds & Mariana Arc & 345 & & & 242 & & ${ }_{14}^{40}$ & 26 & 206 & 列 \\
\hline 72 & Forecast Vent Field & Mariana Arc & 1470 & & 300 & 210 & & 13 & 12 & 282 & 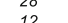 \\
\hline 73 & Mata Tolu (Snail Site) & Tonga Arc & 1820 & & & 314 & 3.4 & 9.9 & 4 & 60 & $T_{4}$ \\
\hline 74 & Volcano O, MTJ Caldera & Tonga Arc & $1635-1470$ & & & & & 14 & 16 & 138 & $\begin{array}{c}4 \\
16\end{array}$ \\
\hline 75 & Brothers Seamount & Kermadec Arc & 1665 & & 5000 & 302 & 2.8 & 1.4 & 83 & 79 & 83 \\
\hline 76 & Clark Seamount & Kermadec Arc & 870 & & & 221 & 4.9 & 1.5 & 28 & 17 & 31 \\
\hline 77 & $\begin{array}{l}\text { Calypso Vent field } \\
\text { Cals }\end{array}$ & Kermadec Arc & $170-220$ & & & 200 & & $<0.01$ & 44 & 0.40 & 44 \\
\hline & $\operatorname{arc}(T-A R C)$ & & & & & & & & & & \\
\hline 78 & PACMANUS & $\begin{array}{l}\text { Manus Basin } \\
\text { Manus Basin }\end{array}$ & $\begin{array}{l}1650-1780 \\
1650\end{array}$ & $\begin{array}{l}\text { ultra-fast } \\
\text { ultra-fast }\end{array}$ & 15000 & 358 & 2.3 & 10 & 409 & 196 & 412 \\
\hline 80 & $\begin{array}{l}\text { Solwara } 5 \\
\text { Solwara } 9\end{array}$ & $\begin{array}{l}\text { Manus Basin } \\
\text { Manus Basin }\end{array}$ & 1680 & $\begin{array}{l}\text { ultra-fast } \\
\text { ultra-fast }\end{array}$ & 30000 & & & $\begin{array}{l}4.6 \\
15\end{array}$ & $\begin{array}{l}28 \\
17\end{array}$ & $\begin{array}{l}113 \\
258\end{array}$ & $\begin{array}{l}28 \\
17\end{array}$ \\
\hline 81 & Solwara 12 & Manus Basin & $1866-1923$ & ultra-fast & & & & 89 & 10 & 列 & 10 \\
\hline 82 & Solwara 13 & Manus Basin & $1997-2006$ & ultra-fast & & & & 44 & 7 & 241 & 10 \\
\hline 83 & Suzette (Solwara 01) & Manus Basin & $1504=000$ & $\begin{array}{l}\text { ultra-fast } \\
\text { ultast }\end{array}$ & 90000 & 303 & 2.3 & 56 & 533 & 41 & 528 \\
\hline 84 & North Su & Manus Basin & 1192 & ultra-fast & & 332 & 0.9 & 7.0 & 18 & 26 & 18 \\
\hline 85 & South Su & Manus Basin & 1309 & ultra-fast & & 293 & 2.6 & 6.2 & 11 & 103 & 11 \\
\hline 86 & FRSC-2 (Tahi Moana-8) & Lau Basin / Fonualei Rift & $1640-1820$ & & & & & 16 & 3 & 504 & 3 \\
\hline 87 & Bransfield Strait & Western Antarctic Peninsula & $1000-1500$ & ultra-slow & & & & 0.51 & 10 & 262 & 10 \\
\hline & ental back-arc basin (BAB- & & & & & & & & & & \\
\hline 88 & Minami Ensai Site & Okinawa Trough & $690-705$ & slow & & 282 & 4.9 & 1.3 & 6 & 55 & 6 \\
\hline 89 & North Knoll, heya Ridge & Okinawa Trough & & slow & & 311 & 4.7 & 3.0 & 48 & 500 & 55 \\
\hline 90 & JADE, Izena Cauldron & Okinawa Trough & 1350 & slow & 5000 & 320 & 4.7 & 1.1 & 67 & 600 & 71 \\
\hline 91 & Hakurei, Izena Cauldron & Okinawa Trough & 1610 & slow & & 326 & 4.7 & 4.5 & 32 & 4900 & 34 \\
\hline 92 & Yaeyama Graben (Irabu West) & Okinawa Trough & 1650 & intermediate & & 151 & & 0.05 & 6 & 198 & 6 \\
\hline & ic back-arc basin (BAB-1O) & & & & & & & & & & \\
\hline 93 & Sumizu Rift & Izu-Bonin Arc & $1530-1600$ & ultra-slow & & & & 0.01 & 5 & 2.5 & 5 \\
\hline 94 & Alice Springs & Mariana Trough & $3640-3595$ & slow & 1000 & 287 & 4.4 & 0.8 & 17 & 164 & 17 \\
\hline $\begin{array}{l}95 \\
96\end{array}$ & $\begin{array}{l}\text { Yamanaka Site } \\
\text { Archean Site }\end{array}$ & Mariana Trough & 2830 & intermediate & & 343 & & 0.25 & 2 & 42 & ${ }^{3}$ \\
\hline 9 & $\begin{array}{l}\text { Archean Site } \\
\text { Pika Site }\end{array}$ & $\begin{array}{l}\text { Mariana Trough } \\
\text { Mariana Trough }\end{array}$ & $\begin{array}{l}2980-3030 \\
1490-1500\end{array}$ & $\begin{array}{l}\text { intermediate } \\
\text { intermediate }\end{array}$ & & $\begin{array}{l}343 \\
330\end{array}-10$ & 29 & $\begin{array}{l}1.3 \\
0.80\end{array}$ & $\begin{array}{r}8 \\
4\end{array}$ & $\begin{array}{l}65 \\
15\end{array}$ & $\begin{array}{l}15 \\
13\end{array}$ \\
\hline 98 & Solwara 11 & Manus Basin & 1310 & $\begin{array}{l}\text { ultra-fast } \\
\text { nast }\end{array}$ & & & & 1.2 & 24 & 146 & 24 \\
\hline 99 & Solwara 18 & Manus Basin & 1310 & intermediate & & & & 0.19 & 2 & 110 & 2 \\
\hline 100 & Tufar 3 & Manus Basin & 2570 & ultra-slow & & 194 & & 31 & 2 & 1115 & 22 \\
\hline 101 & Bronze Age Fort & Manus Basin & 2440 & slow & & & ? & 2.9 & 3 & 226 & 3 \\
\hline 102 & $\begin{array}{l}\text { Vienna Woods (Solwara 2) } \\
\text { Solwara } 3\end{array}$ & $\begin{array}{l}\text { Manus Basin } \\
\text { Manus Basin }\end{array}$ & 2480 & slow & & 302 & 4.2 & 5.5 & 37 & $\begin{array}{l}150 \\
370\end{array}$ & 117 \\
\hline 104 & $\begin{array}{l}\text { Solwarar } 3 \\
\text { Solwara } 10\end{array}$ & $\begin{array}{l}\text { Manus Basin } \\
\text { Manus Basin }\end{array}$ & $\begin{array}{l}2480 \\
2230-2255\end{array}$ & $\begin{array}{l}\text { slow } \\
\text { intermediate }\end{array}$ & & & & $\begin{array}{c}11 \\
0.97\end{array}$ & $\begin{array}{l}26 \\
25\end{array}$ & $\begin{array}{l}370 \\
62\end{array}$ & $\begin{array}{l}26 \\
25\end{array}$ \\
\hline 105 & Solwara 14 & Manus Basin & 2240 & intermediate & & & & 2.9 & 14 & 72 & 14 \\
\hline 106 & Solwara 16 & Manus Basin & $2145-2165$ & fast & & & & 2.5 & 6 & 106 & 6 \\
\hline 107 & Franklin Seamount & Woodlark Basin & $2140-2240$ & slow & & & & 12 & 6 & 277 & 6 \\
\hline 108 & Sog9Field & North Fiji Basin & 1980 & intermediate & & & & 2.2 & 29 & 188 & 40 \\
\hline 110 & Pere Lachaise & $\begin{array}{l}\text { North Fiji Basin } \\
\text { Nath }\end{array}$ & 2000 & intermediate & 5000 & & & 1.3 & 7 & 160 & 23 \\
\hline 1111 & $\begin{array}{l}\text { White Lady (Starmer) } \\
\text { Kus }\end{array}$ & $\begin{array}{l}\text { North Fiji Basin } \\
\text { Pas }\end{array}$ & 1960 & intermediate & & 296 & 4.7 & 2.3 & 17 & 53 & 17 \\
\hline 112 & $\begin{array}{l}\text { Kulo Lasi } \\
\text { Kings Triple Junction }\end{array}$ & $\begin{array}{l}\text { Lau Basin } \\
\text { Lau Basin }\end{array}$ & 1475 & fast & & 345 & 2.2 & 0.5 & 6 & 65 & 6 \\
\hline 113 & $\begin{array}{l}\text { Tahi Moana } 7 \\
\text { Then I }\end{array}$ & Lau Basin & $1880-1940$ & $\begin{array}{l}\text { lutra-last } \\
\text { ultra-fast }\end{array}$ & & & & 73 & 19 & $\begin{array}{l}15 \\
69 \\
69\end{array} \mathrm{l}$ & $\begin{array}{l}78 \\
19 \\
19\end{array} \mathrm{~V}$ \\
\hline 114 & Kilo Moana & Lau Basin & 2619 & fast & & 333 & 2.9 & 4.5 & 18 & 68 & 18 \\
\hline 115 & Towcam & Lau Basin & 2712 & fast & & 328 & 3.6 & 4.9 & 10 & 124 & 10 \\
\hline 116 & Tahi Moana-1 & Lau Basin & $2245-2194$ & fast & & 311 & 3.3 & 5.3 & 22 & 180 & 22 \\
\hline 117 & ABE & Lau Basin & 2140 & fast & & 317 & 3.9 & 2.2 & 15 & 49 & 15 \\
\hline 118 & White Church & Lau Basin (Valu Fa Ridge) & 1850 & intermediate & & & & 2.9 & 25 & 88 & 45 \\
\hline 119 & NVFR-2 & Lau Basin (Valu Fa Rid & $1802-1785$ & intermediate & & & & 3.7 & 11 & 49 & 18 \\
\hline 120 & Tahi Moana-2 & Lau Basin (Valu Fa Ridg & $1832-1845$ & fast & & & & 2.8 & 5 & 116 & 5 \\
\hline 1212 & $\begin{array}{l}\text { NVFR-3 } \\
\text { Tui Malila }\end{array}$ & $\begin{array}{l}\text { Lau Basin (Nalu Fa Rig } \\
\text { Lau Basin (Nalu Fa Ridg }\end{array}$ & & $\begin{array}{l}\text { intermediate } \\
\text { intermediate }\end{array}$ & & 315 & 38 & $\begin{array}{l}2.8 \\
4.7\end{array}$ & $\begin{array}{r}20 \\
29\end{array}$ & $\begin{array}{r}85 \\
96\end{array}$ & 26 \\
\hline 123 & $\begin{array}{l}\text { Telve (Tahi Moana-4) } \\
\text { Telva }\end{array}$ & $\begin{array}{l}\text { Lau basin (Naulu Fa Ridge) } \\
\text { Lau Basin (Valu Fa Ridge) }\end{array}$ & $\begin{array}{l}1819-1868 \\
1636\end{array}$ & $\begin{array}{l}\text { Intermediate } \\
\text { intermediate }\end{array}$ & & & & $\begin{array}{l}4.7 \\
13\end{array}$ & $\begin{array}{r}29 \\
1\end{array}$ & $\begin{array}{l}96 \\
509\end{array}$ & $\begin{array}{r}29 \\
1\end{array}$ \\
\hline 124 & Mariner & Lau Basin (Valu Fa Ridge) & 1910 & intermediate & & 363 & 2.2 & 2.9 & 27 & 90 & 27 \\
\hline 125 & Vai Lili & Lau Basin (Valu Fa Ridge) & 1750 & intermediate & & 334 & 2.0 & 1.2 & 66 & 85 & 96 \\
\hline 126 & Si' Sii' (Tahi Moana-6) & Lau Basin (Valu Fa Ridge) & $1904-1882$ & intermediate & & & & 7.3 & 3 & 198 & 3 \\
\hline 127 & Misiteli (Tahi Moana-5) & Lau Basin (Valu Fa Ridge) & 2031 & intermediate & & & & 14 & 7 & 646 & 7 \\
\hline 128 & Hine Hina & Lau Basin (Valu Fa Ridge) & 1850 & intermediate & & & & 2.4 & 24 & 110 & 39 \\
\hline & olcano (IV) & & & & & & & & & & \\
\hline 129 & Loihi Seamount & Hawaiian Ridge & $1173-1312$ & & & 200 & & -- & - & 6.7 & 9 \\
\hline Intrac & & & & & & & & 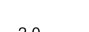 & 5 & 0 & 80 \\
\hline & Atlantis || Deep & Red Sea & 2195 & ultra-slow & & 67 & & 2.0 & 53 & 91 & 94 \\
\hline
\end{tabular}

This compilation of geochemical analyses of marine massive sulfide samples is an update from a version originally created for the International Seabed Authority by the Geological Survey of Canada by Hannington et al. (2004). A detailed reference list for this version is provided in ESM 1

${ }^{1}$ The rates of seafloor spreading are calculated based on MORVEL56 (DeMets et al. 2010) and categorized as ultra-slow ( $\left.<20 \mathrm{~mm} / \mathrm{year}\right)$, slow (20$40 \mathrm{~mm} /$ year), intermediate ( $40-60 \mathrm{~mm} /$ year), fast (60-140 $\mathrm{mm} /$ year), and ultra-fast (>140 $\mathrm{mm} /$ year)

${ }^{2}$ Estimated sizes of SMS deposits are taken from Hannington et al. (2010) 


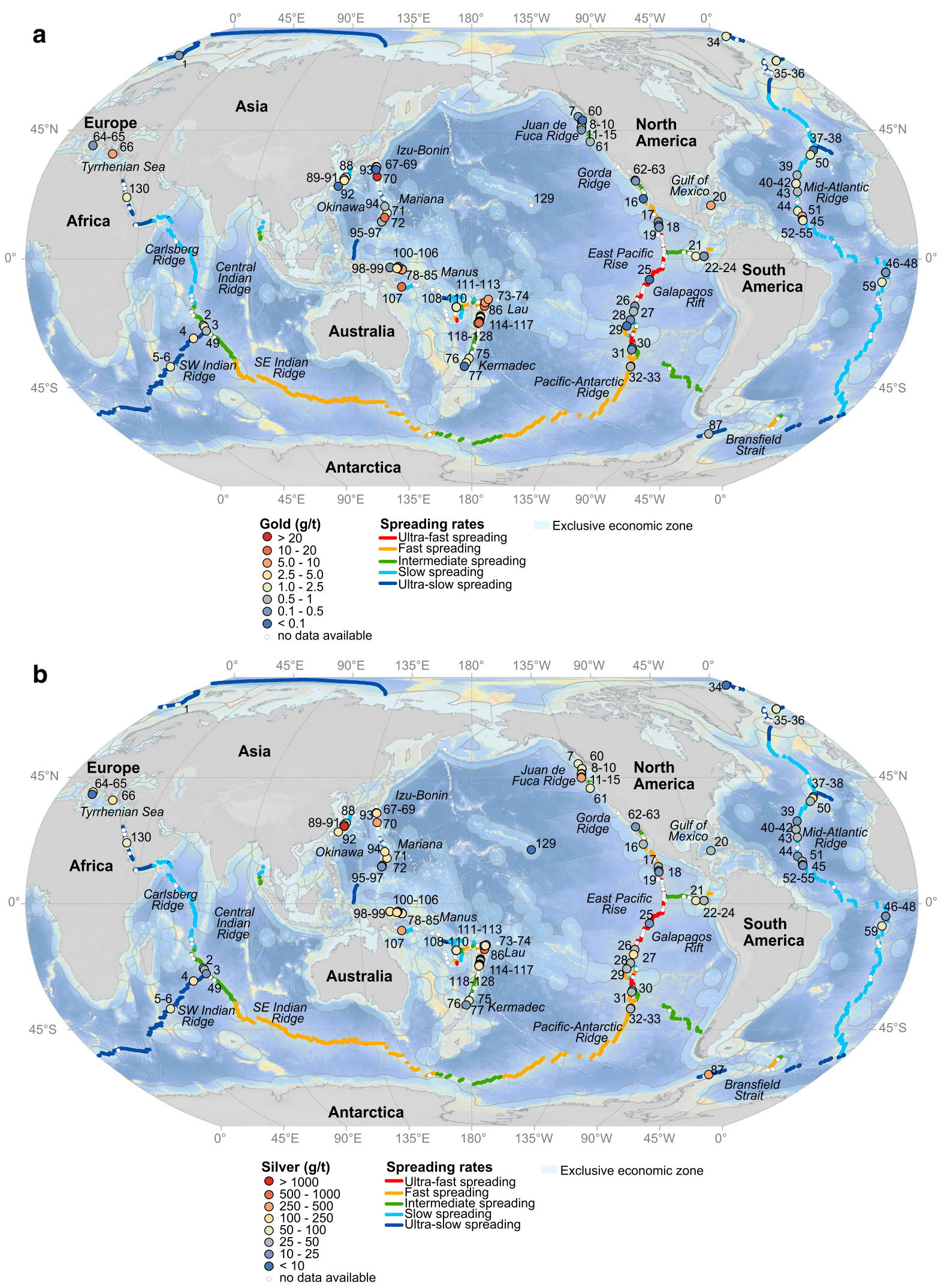

Fig. 1 Locations for a Au- and b Ag-rich SMS deposits in the world's oceans. The color-coded symbols reflect the metal grades. The numbers refer to the deposits listed in Table 1 and the coordinates for all SMS deposits are from Petersen et al. (2016). The Au and Ag concentrations

are taken from an updated compilation of geochemical analyses originally published by Hannington et al. (2004); a detailed description and reference list are provided in Table 1 and in ESM 1, respectively 


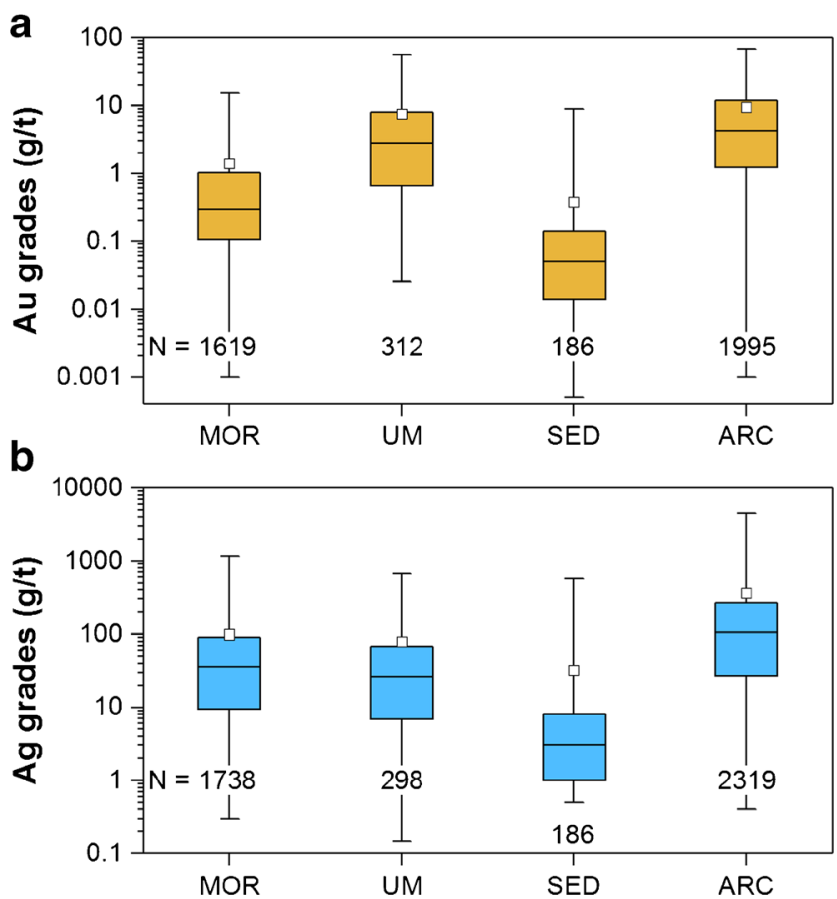

Fig. 2 Box-and-whisker plots of $\mathrm{Au}(\mathbf{a})$ and $\mathrm{Ag}(\mathbf{b})$ concentrations of 130 seafloor massive sulfide deposits according to tectonic/geological settings. The boxes represent the first (25\%) to the third (75\%) quartile, the horizontal line within the boxes is the median (second quartile), and the white squares are the mean values. The whiskers indicate the minimum and maximum values for the range of 1 to $99 \%$ of the data. Abbreviations: $N=$ number of samples, $\mathrm{MOR}=$ mid-ocean ridge, $\mathrm{UM}=$ ultramafic rock-hosted mid-ocean ridge, $\mathrm{SED}=$ sediment-covered midocean ridge, $\mathrm{ARC}=$ arc-rift related environment

$\mathrm{BABB}$, like arc magmas, are enriched in volatiles and incompatible elements but are transitional between MORB and arc basalt. BABB is generated by the extension (depressurization)induced partial melting of a mantle wedge, which has been previously metasomatized by volatiles from a subduction slab (e.g., Pearce et al. 1995). Intracontinental rifts are also important settings for ancient VMS (Hannington et al. 2005), but only one seafloor hydrothermal system is known in an intracontinental rift setting, in the Atlantis II Deep of the Red Sea (Table 1 and Fig. 1).

Gold and Ag concentrations in samples from these different settings span several orders of magnitude, from 0.001 to $43 \mathrm{~g} / \mathrm{t} \mathrm{Au}$ and 0.4 to $4900 \mathrm{~g} / \mathrm{t} \mathrm{Ag}$. Basalthosted and ultramafic rock-hosted massive sulfide deposits located at mid-ocean ridges (e.g., Mid-Atlantic Ridge, East-Pacific Rise, Galapagos Rift) have Au and Ag grades with median values of 0.29 and 2.78 , respectively, with some exceptions where they reach grades that exceed $8 \mathrm{~g} / \mathrm{t} \mathrm{Au}$ and $90 \mathrm{~g} / \mathrm{t} \mathrm{Ag} \mathrm{(Fig.} \mathrm{2).} \mathrm{Deposits} \mathrm{at}$ sediment-covered mid-ocean ridges have low grades, generally less than $0.1 \mathrm{~g} / \mathrm{t} \mathrm{Au}$ and $8 \mathrm{~g} / \mathrm{t} \mathrm{Ag}$. In contrast, SMS located in arc-related rift systems, including the oceanic arcs, transitional arcs, and mature back-arc basins, are characterized by much higher grades. The richest deposits have median grades that exceed $10 \mathrm{~g} / \mathrm{t} \mathrm{Au}$ (in the 10th percentile: Fig. 3a) and are all found in transitional arc and back-arc settings (Table 1 and Fig. 1a). These deposits are located on the Izu-Bonin $\operatorname{arc}(43 \mathrm{~g} / \mathrm{t} \mathrm{Au}$ at the Suiyo Seamount), in the Mariana back-arc (13.3 g/t Au at the Forecast vent field), in the Manus Basin $(15.2 \mathrm{~g} / \mathrm{t} \mathrm{Au}$ at Solwara 9; $12.8 \mathrm{~g} / \mathrm{t}$ and $10.4 \mathrm{~g} / \mathrm{t}$ Au at Solwara 6 and 8, respectively; $10 \mathrm{~g} / \mathrm{t} \mathrm{Au}$ at the Pacmanus Site; $10.6 \mathrm{~g} / \mathrm{t} \mathrm{Au}$ and $31 \mathrm{~g} / \mathrm{t} \mathrm{Au}$, respectively, at Solwara 2 and 3 in the Vienna Woods Area), in the Western Woodlark Basin $(12.4 \mathrm{~g} / \mathrm{t} \mathrm{Au}$ at Franklin Seamount), and in the Lau Basin (16.3 g/t Au at Fonualei Rift, FRSC-2; $13.9 \mathrm{~g} / \mathrm{t}$ $\mathrm{Au}$ at the MTJ Caldera site; $12.9 \mathrm{~g} / \mathrm{t}$ Au at Tahi Moana4; $14.2 \mathrm{~g} / \mathrm{t} \mathrm{Au}$ at Tahi Moana-5). Deposits with median Ag grades in the top $10 \%$ (more than $280 \mathrm{~g} / \mathrm{t} \mathrm{Ag:} \mathrm{Fig.} 3 \mathrm{~b}$ ) are also in arc and back-arc settings: on the Izu-Bonin arc ( $322 \mathrm{~g} / \mathrm{t} \mathrm{Ag}$ at the Suiyo Seamount), in the Manus Basin $(370 \mathrm{~g} / \mathrm{t} \mathrm{Ag}$ at Solwara 2, $1115 \mathrm{~g} / \mathrm{t} \mathrm{Ag}$ at Solwara 3, $284 \mathrm{~g} / \mathrm{t} \mathrm{Ag}$ at Solwara 9, and $452 \mathrm{~g} / \mathrm{t} \mathrm{Ag}$ at Solwara 12), on the Mariana arc (282 g/t Ag at the Forecast vent field), and in the Lau Basin (504 g/t Ag at Fonualei Rift, FRSC2; $509 \mathrm{~g} / \mathrm{t} \mathrm{Ag}$ and $646 \mathrm{~g} / \mathrm{t} \mathrm{Ag}$ at Tahi Moana-4 and Tahi Moana-5, respectively). The highest Ag grades are found in deposits underlain by continental crust in the Okinawa Trough (4900 g/t Ag at Hakurei; $600 \mathrm{~g} / \mathrm{t} \mathrm{Ag}$ at JADE; $500 \mathrm{~g} / \mathrm{t} \mathrm{Ag}$ at North Knoll).

Caution is needed when interpreting the reported $\mathrm{Au}$ and Ag grades because of the highly variable sample populations, which range from dredged samples with poorly constrained locations, multiple samples from the same location (e.g., an individual chimney complex), and comprehensive sample collections of entire areas or deposits, including active and inactive parts (e.g., Petersen et al. 2016). The majority of the analyses are of dredged samples from sulfide mounds, debris, and especially active chimneys collected during sampling of high-temperature fluids. Evidence of a sampling bias is seen in a number of examples. For example, the spectacular $\mathrm{Ag}$ grades reported for the Hakurei deposit in the Okinawa Trough (4900 ppm Ag) are the result of analyses of multiple subsamples from a single Ag-rich chimney, while most of the other chimneys recovered from the deposit have grades of only a few hundred parts per million (Table 1). Data from drilling of the TAG, Snakepit, Middle Valley (Bent Hill and ODP mound) and Solwara 1 deposits (Table 2) also shows significant variability in grades between the interior of a deposit and samples from the surface. All of the drilled deposits show similar trends of $\mathrm{Au}$ and $\mathrm{Ag}$ enrichments at or near the surface and depletion in the interior. Thus, reported grades from most seafloor deposits that have not been drilled cannot be compared with reserves and resources reported for wellcharacterized land-based mineral deposits. Only two large Aurich deposits, in terms of size and tonnage, are presently known among the volcanic-hosted SMS occurrences: the 

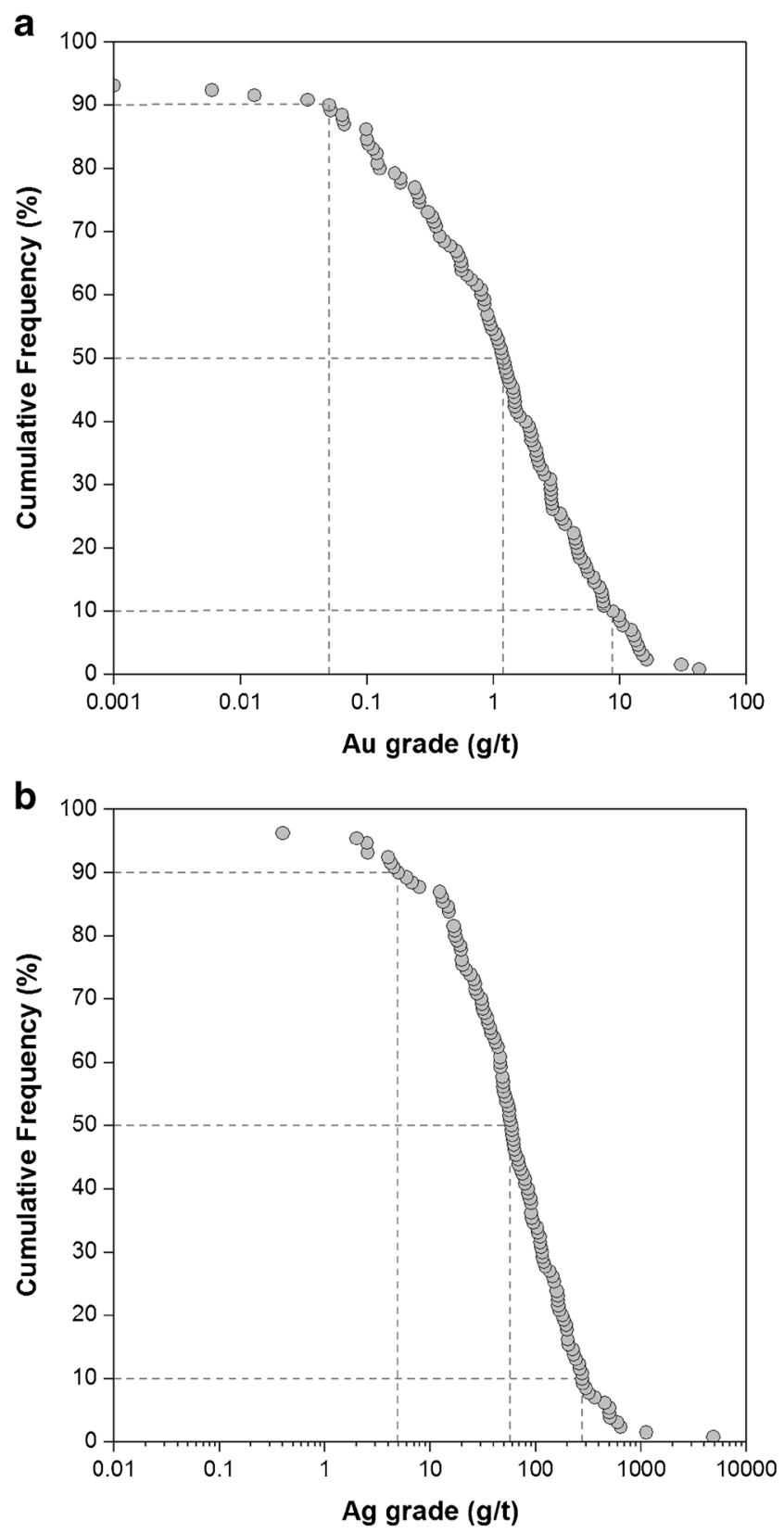

Fig. 3 Cumulative frequency plot of the median $\mathbf{a} \mathrm{Au}$ and $\mathbf{b}$ Ag grades in the collected surface samples of 130 SMS deposits. The gray dashed lines indicate the 10th, 50th, and 90th percentile of the data. Data sources are provided in ESM 1

Solwara 1 deposit in the Eastern Manus Basin and the Hakurei deposit in the Okinawa Trough, which could contain between 10 and $15 \mathrm{t} \mathrm{Au}$, respectively (Nautilus Minerals Inc. 2012; JOGMEC 2016). The largest accumulation of Au on the modern seafloor is in the metalliferous muds of the Atlantis II Deep, which are estimated to contain $\sim 45 \mathrm{t}$ of $\mathrm{Au}$ (Laurila et al. 2015). In most cases, however, it is not possible to make direct comparisons of metal content with land-based deposits owing to the nature of the sampling and the methods of reporting mine production.

\section{Precious metal associations and processes of enrichment}

Gold and silver are associated with a wide range of different sulfide mineral assemblages in SMS deposits in both midocean ridge systems and arc or back-arc systems. They include $\mathrm{Cu}-\mathrm{Au}$-rich chimneys in the calderas of arc-front volcanoes (Sunrise, Brothers); large $\mathrm{Cu}-\mathrm{Zn}$ deposits in earlystage arc rifts (Solwara 1 deposit in the Eastern Manus Basin); polymetallic $\mathrm{Zn}-\mathrm{Cu}-\mathrm{Pb}$ deposits at rifted continental margins (Hakurei deposit in the Okinawa Trough); ultramafic rock-hosted $\mathrm{Cu}-\mathrm{Au}$ mineralization at slow-spreading midocean ridges (Logatchev, Semyenov, Ashadze deposits on the Mid-Atlantic Ridge); deposits that have been strongly enriched by zone refinement (TAG, MIR, and Alvin zones at the Mid-Atlantic Ridge); in relatively shallow submarine hydrothermal systems affected by boiling (including both $\mathrm{Cu}-$ and Zn-rich chimneys: Axial Seamount on the Juan de Fuca Ridge); and in at least one large-tonnage, low grade brine-pool deposit in Atlantis II Deep of the Red Sea (Table 3) (Hannington et al. 1986, 1991a; Hannington and Scott 1988, 1989a, b; Herzig and Hannington 1990; Petersen et al. 2002). The different styles of mineralization reflect very different conditions and processes of $\mathrm{Au}$ and $\mathrm{Ag}$ enrichment. The two principal geochemical associations recognized in ancient massive sulfide deposits, $\mathrm{Cu}-\mathrm{Au}$ and $\mathrm{Zn}-\mathrm{Au}$ (Huston et al. 2011), are also evident in the global data for SMS (Fig. 4a). The data for $\mathrm{Ag}$ are shown in Fig. $4 \mathrm{~b}$. In many deposits, a strong $\mathrm{Zn}-\mathrm{Au}$ association has been attributed to mixing and cooling of the hydrothermal fluids causing deposition of gold at low temperatures (e.g., $<250{ }^{\circ} \mathrm{C}$ ), typical of white smoker chimneys (Hannington and Scott 1989a). However, temperature, which is the main influence on $\mathrm{Cu}$-rich versus $\mathrm{Zn}$-rich mineralization, cannot be the only control on Au enrichment, because high concentrations of Au are found in both assemblages. This distinctly bimodal distribution is illustrated in Fig. 5, which shows the wide range of $\mathrm{Au}$ concentrations in different $\mathrm{Cu}$ rich and $\mathrm{Zn}$-rich sulfides from deposits in the Eastern Manus Basin. In this case, there is no correlation between the absolute $\mathrm{Au}$ grade and the particular $\mathrm{Cu}-\mathrm{Au}$ or $\mathrm{Zn}-\mathrm{Au}$ association. Another major influence on the distribution of precious metals is the process of hydrothermal reworking or "zone-refining," originally described by Barton $\mathrm{Jr}$ (1978) and adapted to the Kuroko deposits by Eldridge et al. (1983). It involves the continuous dissolution and reprecipitation of early-formed minerals by the flow of high-temperature fluids through the deposit, resulting in the common enrichment of $\mathrm{Au}$ and $\mathrm{Ag}$ with $\mathrm{Zn}$ at the cooler outer margins (Hannington et al. 1998). These $\mathrm{Zn}-\mathrm{Au}$ assemblages also commonly have anomalous trace element geochemistry, including co-enrichments of the epithermal suite (Ag, $\mathrm{As}, \mathrm{Sb}, \mathrm{Hg}$ ).

A number of different processes have been advanced to explain the $\mathrm{Cu}-\mathrm{Au}$ association. Notable co-enrichment of 
Table 2 Comparison of average bulk composition surface samples with drill core samples from selected seafloor massive sulfide deposits

\begin{tabular}{|c|c|c|c|c|c|c|}
\hline Location & $N$ & $\mathrm{Cu}(\mathrm{wt} \%)$ & $\mathrm{Zn}(\mathrm{wt} \%)$ & $\mathrm{Pb}(\mathrm{wt} \%)$ & $\mathrm{Au}(\mathrm{ppm})$ & $\mathrm{Ag}(\mathrm{ppm})$ \\
\hline \multicolumn{7}{|c|}{ TAG (Mid-Atlantic Ridge) } \\
\hline Surface samples & 172 & 5.3 & 8.4 & 0.03 & 2.7 & 171 \\
\hline Core samples & 311 & 2.5 & 0.47 & $<0.01$ & 0.35 & 5.0 \\
\hline \multicolumn{7}{|c|}{ Snakepit (Mid-Atlantic Ridge) } \\
\hline Surface samples & 93 & 9.0 & 4.6 & 0.03 & 1.8 & 62 \\
\hline Core samples & 14 & 10 & 4.7 & 0.03 & 0.6 & 16 \\
\hline \multicolumn{7}{|c|}{ Middle Valley (Bent Hill) } \\
\hline Surface samples & 166 & 0.73 & 2.8 & 0.03 & 0.42 & 17 \\
\hline Core samples & 87 & 1.2 & 1.5 & 0.02 & 0.08 & 4.0 \\
\hline \multicolumn{7}{|c|}{ Middle Valley (ODP mound) } \\
\hline Surface samples & - & - & - & - & - & \\
\hline Core samples & 17 & 3.1 & 14.2 & $<0.01$ & - & 8.0 \\
\hline \multicolumn{7}{|c|}{ Solwara 1 (Manus Basin) } \\
\hline Surface samples & 250 & 9.7 & 5.4 & 1.1 & 15 & 174 \\
\hline Core samples & 984 & 5.2 & 0.51 & 0.10 & 4.3 & 24 \\
\hline \multicolumn{7}{|c|}{ Palinuro Seamount (Tyrrhenian Sea) } \\
\hline Surface samples & 20 & 0.38 & 13 & 6.5 & 2.6 & 202 \\
\hline Core samples & 36 & 1.6 & 2.8 & 1.9 & 0.4 & 130 \\
\hline
\end{tabular}

Modified from Hannington et al. (2010) and Petersen et al. (2014)

$\mathrm{Cu}$ and $\mathrm{Au}$ has been found in black smoker chimneys from volcanic arcs, such as 10-20 g/t Au in Cu-rich chimneys from Suiyo Seamount on the Izu-Bonin arc and in the deposits in the eastern Manus Basin (Tsunogai et al. 1994; Watanabe and Kajimura 1994; Moss and Scott 2001). The concentrations of $\mathrm{Au}$ are orders of magnitude higher than in similarly $\mathrm{Cu}$-rich black smokers from the mid-ocean ridges, suggesting that $\mathrm{Au}$ concentrations in the vent fluids must be much higher. The most common interpretation is that the Au is sourced from magmatic volatiles and deposited mostly in high-temperature $\mathrm{Cu}$-rich chimneys, but there may be relatively little accumulation of massive sulfide (Dekov and Savelli 2004; Törmänen and Koski 2005; Melekestseva et al. 2010, 2017; Berkenbosch et al. 2012; Iizasa et al. 2018). Other trace elements, such as $\mathrm{Bi}$ and $\mathrm{Te}$, show covariations with $\mathrm{Au}$ enrichment in these chimneys, reaching concentrations of up to $200 \mathrm{ppm} \mathrm{Bi}$ and $150 \mathrm{ppm}$ Te (Watanabe and Kajimura 1994; Moss and Scott 2001). The $\mathrm{Cu}-\mathrm{Au}-\mathrm{Bi}-\mathrm{Te}$ association may reflect a felsic magmatic source for the metals, similar to that observed in subaerial magmatic hydrothermal systems (Hannington et al. 2005). Discrete Bi telluride minerals also have been documented in massive sulfides at Brothers, Palinuro Seamount, and in deposits on the Izu-Bonin arc (Dekov and Savelli 2004; Törmänen and Koski 2005; Melekestseva et al. 2010, 2017; Berkenbosch et al. 2012; Iizasa et al. 2018). The most Au-rich samples also include complex mineral assemblages including abundant bornite, tennantite, or other sulfosalts. The latter commonly include distinctive high-sulfidation minerals, such as the enargiteluzonite in the Eastern Manus Basin (Petersen et al. 2002;

Table 3 Tectonic settings, metal associations, and styles of mineralization of Au-rich seafloor hydrothermal systems

\begin{tabular}{llll}
\hline Deposit type/setting & Metal association & Source of Au enrichment & Examples ${ }^{1}$ \\
\hline Arc volcano & $\mathrm{Cu}-\mathrm{Au}$ & Magmatic-hydrothermal & Sunrise, Brothers \\
Arc-back-arc rift & Au-rich polymetallic & Magmatic-hydrothermal & Solwara 1 \\
Rifted continental margin & Au-rich polymetallic & Enriched continental crust & Okinawa Trough \\
MOR (deep) & $\mathrm{Zn}-\mathrm{Au}$ & Zone-refining & TAG, MIR, Alvin \\
MOR (shallow) & $\mathrm{Zn}-\mathrm{Au}, \mathrm{Cu}-\mathrm{Au}$ & Boiling & Axial Seamount \\
Ultramafic-hosted & $\mathrm{Cu}-\mathrm{Au}$ & Ultramafic (mantle) sources & Logatchev, Ashadze \\
Brine pool & $\mathrm{Au}-\mathrm{pyrite}$ & Sediment (diagenetic) & Atlantis II Deep \\
\hline
\end{tabular}

${ }^{1}$ See text for description 
Fig. 4 Ternary plots of $\mathrm{Cu}, \mathrm{Zn}$, and $\mathrm{Pb}$ concentrations in surface samples of 130 SMS deposits. The number of analyses for each deposit is shown in Table 1. The color code corresponds to the $\mathrm{Au}$ (a) and $\mathrm{Ag}$ (b) concentrations of the corresponding samples, with symbols for high metal concentrations plotted on top of symbols with low metal concentrations to show where the highest grades occur. Data sources are provided in ESM 1
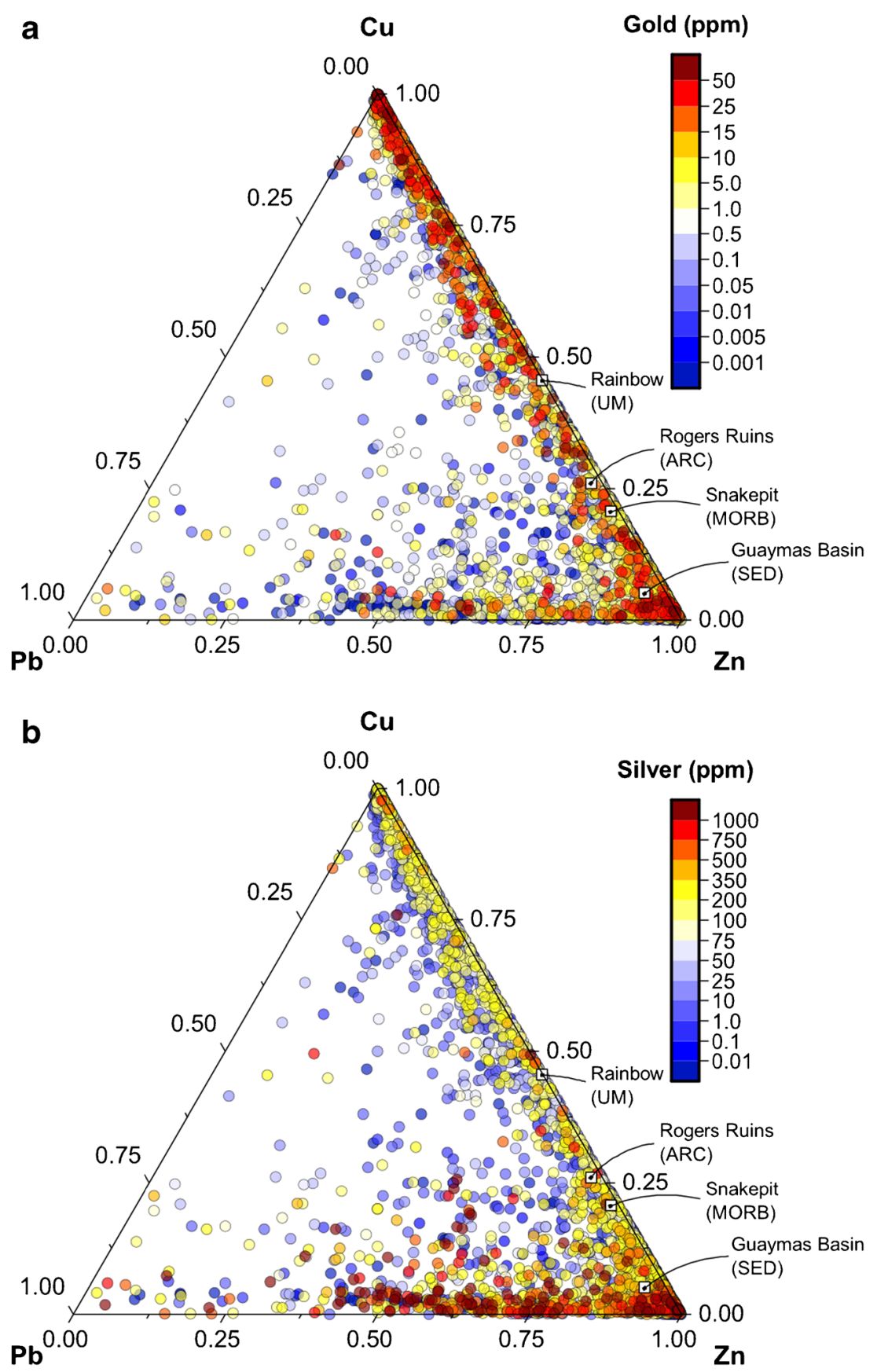

Dekov and Savelli 2004; Törmänen and Koski 2005; Melekestseva et al. 2010, 2017; Berkenbosch et al. 2012; Iizasa et al. 2018). However, normal mid-ocean ridge black smokers, which can also be Au-rich, typically do not show any of these trace element enrichments or high-sulfidation minerals, implying that other processes may also account for the $\mathrm{Cu}-\mathrm{Au}$ association.

The different trace element associations with $\mathrm{Au}$ and $\mathrm{Ag}$ reflect a combination of the conditions of mineralization and the source rocks. In particular, hydrothermal fluids in maficor ultramafic rock-dominated settings are enriched in metals such as $\mathrm{Cu}, \mathrm{Fe}, \mathrm{Co}, \mathrm{Se}$, and $\mathrm{Ni}$, whereas volcanic arc and backarc settings are enriched metals such as $\mathrm{Pb}, \mathrm{As}, \mathrm{Sb}$, and $\mathrm{Ag}$ (Hannington et al. 2005). Spearman's rank correlation coefficient $(\rho)$ calculated for these elements (Fig. 1 in ESM 2) show two groups that are positively correlated with $\mathrm{Au}$ : (1) highly mobile epithermal elements (Ag, As, $\mathrm{Sb}, \mathrm{Hg}, \mathrm{Tl}, \mathrm{Cd}$ ) typical of low-temperature Zn-rich assemblages and (2) other trace elements ( $\mathrm{In}, \mathrm{Ga}, \mathrm{Ge}$ ) that are found in higher-temperature $\mathrm{Cu}$ rich assemblages. The range of concentrations of a number of these elements in samples from deposits in different settings is illustrated in Fig. 6. The source rocks control, possible direct 


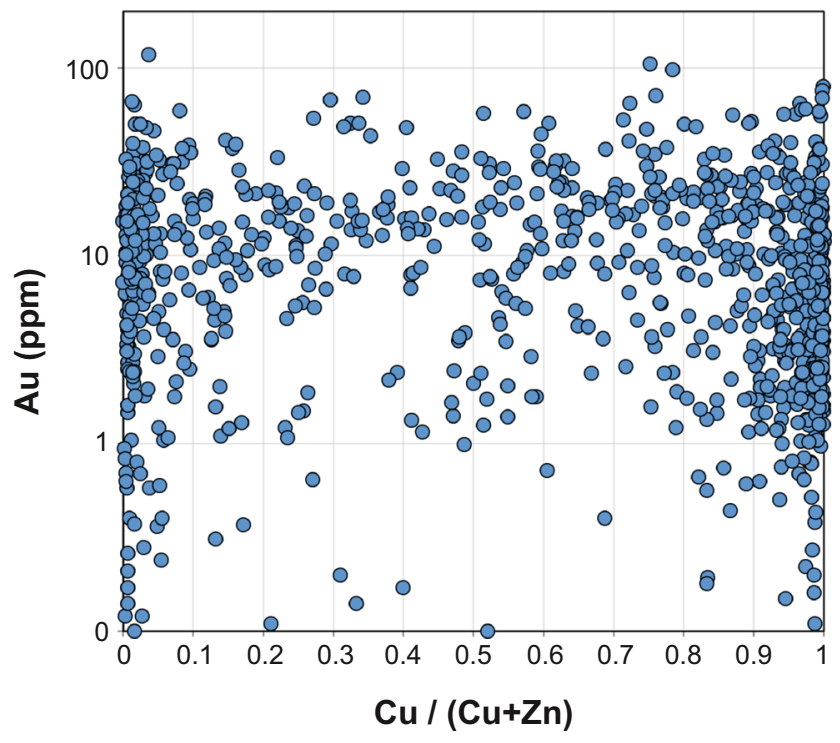

Fig. 5 Gold grade distribution in massive sulfide deposits of the Eastern Manus Basin (data from eight deposits, including Solwara 1: sources are provided in ESM 1). The dataset was chosen specifically because the sample collection is well sorted between $\mathrm{Cu}$-rich and $\mathrm{Zn}$-rich samples. The plot shows that high gold grades can occur in both sample types. However, there is no correlation between the absolute Au grade and the particular $\mathrm{Cu}-\mathrm{Au}$ or $\mathrm{Zn}-\mathrm{Au}$ association

magmatic contributions, and temperature-dependent solubilities that influence the transport and deposition of the trace elements have been reviewed by Monecke et al. (2016).

\section{Precious metal mineralogy}

Although exceptional $\mathrm{Au}$ and $\mathrm{Ag}$ concentrations can be found in many deposits, discrete gold and silver minerals or their alloys are rarely observed (reported in only 18 deposits: Table 4). In a few case where native gold and silver are observed, a close paragenetic relationship exists between Asand Sb-bearing sulfosalts and the native gold has been noted (e.g., Hannington et al. 1991b, 1995; Petersen et al. 2002), which has been attributed by previous workers to coprecipitation at relatively low temperatures. Tennantite $[\mathrm{Cu}$, $\left.\mathrm{Ag}, \mathrm{Zn}, \mathrm{Fe})_{12} \mathrm{As}_{4} \mathrm{~S}_{13}\right]$ and tetrahedrite [ $(\mathrm{Cu}, \mathrm{Fe}, \mathrm{Ag}$, $\mathrm{Zn})_{12} \mathrm{Sb}_{4} \mathrm{~S}_{13}$ ] are the most common sulfosalts (e.g., Monecke et al. 2016). Native gold (commonly of high purity) and Ag-poor electrum are found in some deposits at midocean ridges, including sites with mainly ultramafic footwalls, but native $\mathrm{Ag}$ is rarely observed. Most $\mathrm{Ag}$ is present in $\mathrm{Ag}$ bearing sulfosalts, such as tetrahedrite. In the ultramafichosted Logatchev deposit, native gold has been found in association with chalcopyrite, bornite, and covellite (Murphy and Meyer 1998; Moss and Scott 2001), whereas in the Beebe hydrothermal field, native gold has been found with pyrrhotite and iron oxides but rarely with chalcopyrite (Webber et al. 2017). Native gold has also been reported in opaline silica from the basalt-hosted Semyenov-2 hydrothermal field (Melekestseva et al. 2010, 2017). Abundant Au-rich electrum has been found in hydrothermally reworked sulfides from the TAG hydrothermal field from the Mid-Atlantic Ridge (Hannington et al. 1995). Grain coarsening appears to be an important process during hydrothermal reworking, as suggested by Hannington et al. (1995), explaining the large grain sizes (up to $10 \mu \mathrm{m}$ ) and the high-fineness of the gold in sphalerite veins cutting the massive sulfides. Some native gold in the TAG deposit is interpreted to be enriched together with $\mathrm{Cu}$ in secondary digenite, covellite, and bornite by supergene alteration processes (Hannington et al. 1988).

Native gold, electrum (>20 wt.\% Ag) and Ag-bearing sulfosalts are more common in arc and back-arc settings (seven deposits, Table 4). These have been reported in sphalerite-rich massive sulfides from the Lau Basin (Herzig et al. 1993), in Cu-rich sulfides in chalcopyrite and bornite in the Manus Basin (Moss and Scott 2001; Ihle et al. 2005), Ba$\mathrm{Zn}-\mathrm{Pb}$-rich sulfides from the Okinawa Trough (Halbach et al. 1993), and in the barite-silica chimneys at Franklin Seamount in the Woodlark Basin (Binns et al. 1997). Chalcopyrite from a chimney interior sampled at the Brothers volcano contains distinct bands, $\sim 50-200 \mu \mathrm{m}$ wide, that have Au contents exceeding $300 \mathrm{ppm}$, and in a single spot $\left(\sim 50 \mu \mathrm{m}^{2}\right)$ up to $1.55 \mathrm{wt} \%$ (Berkenbosch et al. 2012). Elsewhere, Ag-rich electrum and Ag-bearing sulfosalts have been found in siliceous vein networks resembling epithermal-style mineralization, such as at Conical Seamount, an alkaline volcano offshore from the giant Ladolam gold deposit on Lihir Island, PNG (Petersen et al. 2002). In the Higashi-Aogashima hydrothermal field, unusually large gold crystals (up the $150 \mu \mathrm{m}$ length) have been identified in amorphous silica, and smaller gold particles have been found in sulfidic sediments, which were interpreted as "fallout" from hydrothermal plumes (Iizasa et al. 2018).

A number of different mechanisms have been proposed for the direct precipitation of gold in sulfide chimneys. Hannington et al. 1986, Hannington and Scott 1989a, Hannington et al. 1991b) recognized the importance of direct precipitation of gold in diffuse hydrothermal vents, in which mixing with seawater played an important role in the cooling and oxidation of the fluids. More recently, Webber et al. (2017) proposed entrapment of gold nanoparticles by diffuse flow through black smoker "beehive chimneys" in the Beebe hydrothermal field. Craddock (2009) suggested a similar mechanism for gold deposition in low-temperature, white smoker "diffusers" in the Eastern Manus Basin. In both cases, the large surface area of the minerals in the beehive-type chimneys was considered to be crucial for the trapping of gold particles. Yang and Scott (2006) suggested a process of direct precipitation of gold in massive sulfide chimneys at the Pacmanus site from magmatic volatiles that degassed through submarine 

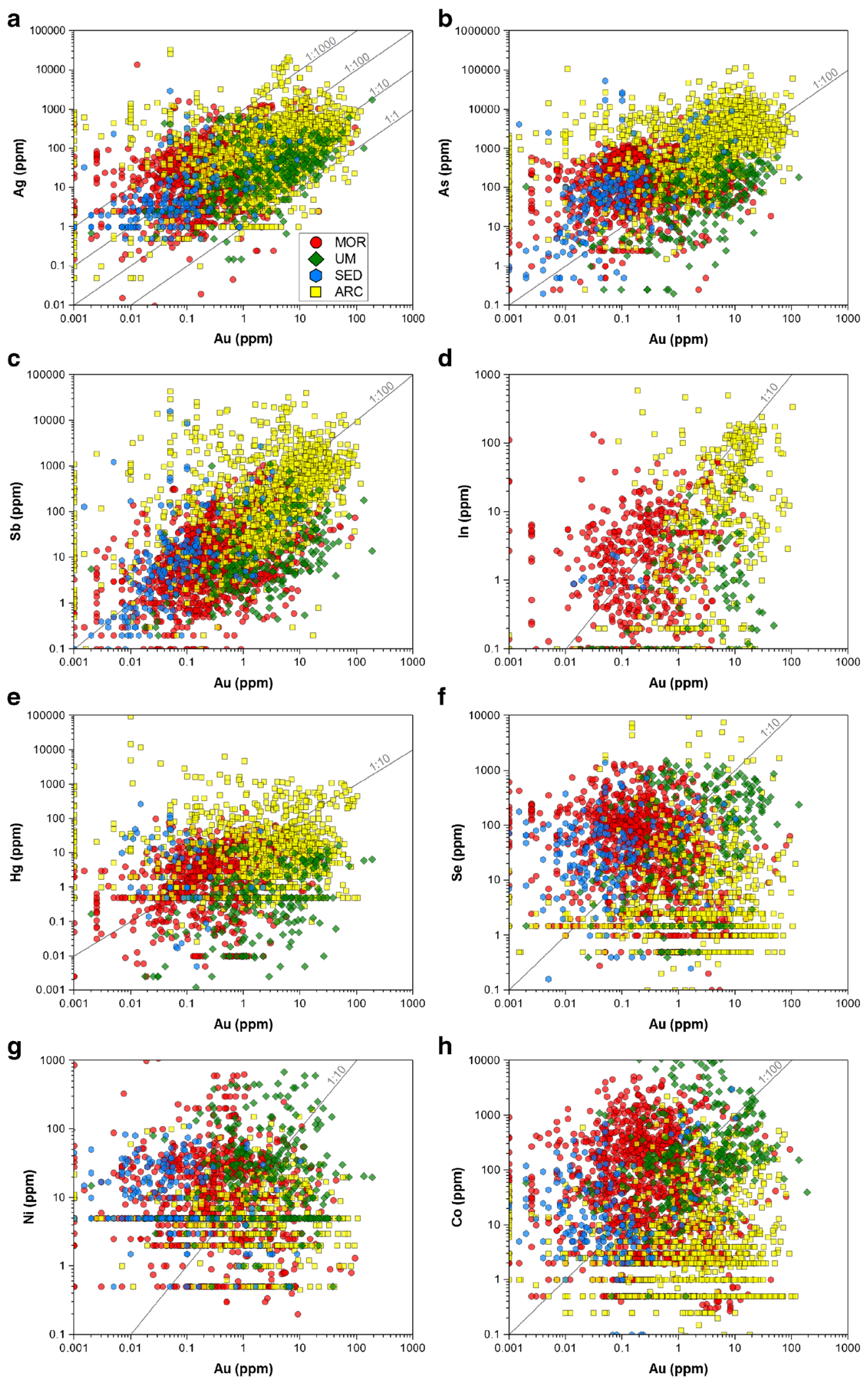

Fig. 6 Bivariate plots for the element pairs a $\mathrm{Au}-\mathrm{Ag}, \mathbf{b} \mathrm{Au}-\mathrm{As}, \mathbf{c} \mathrm{Au}-\mathrm{Sb}$, $\mathbf{d} \mathrm{Au}-\mathrm{In}, \mathbf{e} \mathrm{Au}-\mathrm{Hg}, \mathbf{f} \mathrm{Au}-\mathrm{Se}, \mathbf{g ~ A u}-\mathrm{Ni}$, and $\mathbf{h} \mathrm{Au}-\mathrm{Co}$. The plotted data are for individual surface samples from 130 SMS deposits. The number of analyses for each deposit is shown in Table 1 . The color and shape of the data points indicate the geological/tectonic environment of the

corresponding deposits. Note: In cases where element concentrations reported in the literature are at or below detection $(N<5 \%)$, the plotted values are half the detection limit. These can be recognized in the plots as horizontal or vertical arrays of data points at low concentrations 
Table 4 Occurrences of gold- and silver-bearing phases, associated ore mineralogy, and textural features of Au-rich seafloor massive sulfide deposits

\begin{tabular}{lllll}
\hline Deposit & Region & $\begin{array}{l}\text { Geological } \\
\text { setting }\end{array}$ & Precious metal mineralogy & Ore mineralogy \\
\hline $49.6^{\circ}$ (Longqi) & $\begin{array}{c}\text { Southwest } \\
\text { Indian Ridge }\end{array}$ & MOR & Native Au & $\begin{array}{c}\text { Pyrite, marcasite, and } \\
\text { isocubanite; Zn-rich } \\
\text { assemblages with sphalerite, } \\
\text { marcasite, and isocubanite }\end{array}$
\end{tabular}

Textural features

$\begin{array}{lll}\text { Beebe } & \begin{array}{c}\text { Cayman } \\ \text { Trough }\end{array} & \text { MOR } \\ \text { Edmond Field } & \begin{array}{c}\text { Central Indian } \\ \text { Ridge }\end{array} & \text { MOR }\end{array}$

\begin{tabular}{|c|c|c|c|}
\hline MIR Mound & $\begin{array}{l}\text { Mid-Atlantic } \\
\text { Ridge }\end{array}$ & MOR & Native $\mathrm{Au}(\leq 5.9$ wt $\% \mathrm{Ag})$ \\
\hline Snakepit & $\begin{array}{l}\text { Mid-Atlantic } \\
\text { Ridge }\end{array}$ & MOR & Native $\mathrm{Au}$ \\
\hline TAG mound & $\begin{array}{l}\text { Mid-Atlantic } \\
\text { Ridge }\end{array}$ & MOR & Native Au \\
\hline Ashadze-1 & $\begin{array}{l}\text { Mid-Atlantic } \\
\text { Ridge }\end{array}$ & UM & $\begin{array}{l}\text { Native } \mathrm{Au} \text {, native } \mathrm{Ag} \text {, } \\
\text { electrum, acanthite }\end{array}$ \\
\hline Logatchev $(1+2)$ & $\begin{array}{l}\text { Mid-Atlantic } \\
\text { Ridge }\end{array}$ & UM & $\begin{array}{l}\text { Native } \mathrm{Au}(\leq 6 \mathrm{wt} \% \mathrm{Ag}) \text {, } \\
\text { electrum }\end{array}$ \\
\hline
\end{tabular}

Rainbow Mid-Atlantic

UM Ridge

Semyenov-2
Mid-Atlantic UM
Ridge
Native $\mathrm{Au}$, electrum ( $\leq 13$ wt $\%$ Ag); minor $\mathrm{Au}-\mathrm{Sb}$ alloys

Native Au, native $\mathrm{Ag}$, electrum; argentotennantite, pearceite and/or acanthite, Ag nanoparticles

Native $\mathrm{Au}(\leq 5.9$ wt $\% \mathrm{Ag})$

Pyrrhotite, chalcopyrite, sphalerite, bornite, chalcocite, amorphous silica, iron oxides, and anhydrite

Pyrite, chalcopyrite, marcasite, sphalerite,

tennantite-tetrahedrite, amorphous silica, anhydrite and $\mathrm{Fe}$-oxyhydroxides

Massive and recrystallized chalcopyrite, pyrite, and sphalerite

Chalcopyrite and pyrite in core zone; isocubanite in stockwork zone; sphalerite, pyrrhotite, and isocubanite in the uppermost zone

Pyrite, sphalerite, chalcopyrite, marcasite, bornite, amorphous silica, and secondary sulfides

Chalcopyrite-, pyrrhotite-isocubanite-, and sphalerite-dominated chimneys; minor bornite, pyrite, marcasite, wurtzite, digenite, chalcocite, and covellite

Sphalerite, chalcopyrite, isocubanite, pyrite and marcasite, minor barite, and clays

Pyrrhotite, isocubanite, chalcopyrite and sphalerite, very pentlandite, millerite, and linnaeite/
Native $\mathrm{Au}$ and electrum $(\leq 23 \mathrm{wt} \% \mathrm{Ag})$, native $\mathrm{Ag}$, stutzite $\left(\mathrm{Ag}_{5}-\mathrm{Te}_{3}\right)$ sphalerite, wurtzite, marcasite, pyrite and
Native Au occurs in Zn-rich assemblages in cavities or as inclusions in sphalerite. Some grains present as inclusions in pyrite or interstices between pyrite and sphalerite

Native Au and electrum as inclusions within and at grain boundaries between pyrrhotite, iron oxides, and rarely chalcopyrite

Native $\mathrm{Au}$ is associated with sphalerite and anhydrite or barite. Electrum and acanthite as inclusions and at grain boundaries chalcopyrite and sphalerite. Nanoparticles of native $\mathrm{Ag}$ in tennantite, sphalerite, and chalcopyrite

Native Au in the interstices or in voids in recrystallized chalcopyrite and pyrite.

Native Au inclusions in digenite, bornite and opal/goethite in altered, oxidized $\mathrm{Cu}$-rich chimneys

Native Au in fine-grained secondary digenite on the margins of altered chalcopyrite

Native Au in observed isocubanite-chalcopyrite aggregates; electrum is associated with chalcopyrite, sphalerite, and isocubanite; native $\mathrm{Ag}$ with sphalerite

Native Au inclusions in primary chalcopyrite, in bands of bornite replacing chalcopyrite, in covellite replacing bornite and chalcopyrite; electrum as inclusions within sphalerite (Logatchev 2 many gold grains are also associated with am. silica)

Native $\mathrm{Au}$ associated with Bi-rich melonite $\left(\mathrm{NiTe}_{2}\right)$ in the core of active $\mathrm{Cu}$-rich chimneys

Chalcopyrite, isocubanite, opal, Native Au with am. silica and covellite, minor atacamite, galena, pyrrhotite, barite, and rarely with isocubanite, chalcopyrite and sphalerite; Ag occurs in aragonite 
Table 4 (continued)

\begin{tabular}{|c|c|c|c|c|c|}
\hline Deposit & Region & $\begin{array}{l}\text { Geological } \\
\text { setting }\end{array}$ & Precious metal mineralogy & Ore mineralogy & Textural features \\
\hline Escanaba Trough & Gorda Ridge & SED & $\begin{array}{l}\text { Native } \mathrm{Au} \text { and electrum } \\
(\leq 33 \mathrm{wt} \% \mathrm{Ag}) \text {, maldonite, } \\
\text { unknown } \mathrm{Au} \text {-bearing } \\
\text { mineral }\left(\mathrm{AuBi}_{5} \mathrm{~S}_{4}\right)\end{array}$ & $\begin{array}{l}\text { Pyrrhotite, isocubanite, } \\
\text { chalcopyrite, sphalerite, } \\
\text { pyrite, marcasite and barite, } \\
\text { minor sulfarsenides, } \\
\text { arsenides, Bi-bearing } \\
\text { minerals, and galena }\end{array}$ & $\begin{array}{l}\text { Native Au, electrum, maldonite } \\
\text { and unknown Au-Bi sulfides } \\
\text { as inclusions/overgrowths on } \\
\text { arsenopyrite, glaucodot, } \\
\text { cobaltite, loellinggite, } \\
\text { safflorite, native bismuth, } \\
\text { Bi-tellurides, and Bi-Te } \\
\text { sulfides; secondary Au } \\
\text { observed in interstice of } \\
\text { altered pyrrhotite and } \\
\text { intergrown with native sulfur }\end{array}$ \\
\hline Brothers & Kermadec Arc & I-ARC & $\begin{array}{l}\text { Calaverite }\left(\mathrm{AuTe}_{2}, \leq 40 \mathrm{wt} \%\right. \\
\mathrm{Au}), \mathrm{Au}-\mathrm{Bi} \text {-bearing } \\
\text { tellurides }\end{array}$ & $\begin{array}{l}\text { Chalcopyrite, sphalerite, } \\
\text { bornite, barite, minor pyrite, } \\
\text { chalcocite, covellite, } \\
\text { sulfosalts, sphalerite, and iron } \\
\text { oxides in } \mathrm{Cu} \text { - and } \mathrm{Zn} \text {-rich } \\
\text { chimneys }\end{array}$ & $\begin{array}{l}\mathrm{Au}-(\mathrm{Bi}) \text {-tellurides in } \\
\text { chalcopyrite }\end{array}$ \\
\hline Higashi-Aogashima & $\begin{array}{l}\text { Izu-Ogasawara } \\
\text { arc }\end{array}$ & I-ARC & $\begin{array}{l}\text { Native } \mathrm{Au}(\leq 18.2 \mathrm{wt} \% \mathrm{Ag}) \\
\text { hessite }\left(\mathrm{Ag}_{2} \mathrm{Te}\right)\end{array}$ & $\begin{array}{l}\text { Sphalerite, chalcopyrite, } \\
\text { tennantite, jordanite, pyrite, } \\
\text { barite, and amorphous silica }\end{array}$ & $\begin{array}{l}\text { Native Au associated with } \\
\text { sphalerite, chalcopyrite, } \\
\text { pyrite, tennantite, hessite, } \\
\text { galena, amorphous silica, and } \\
\text { barite (in sulfides and } \\
\text { metalliferous sediments) }\end{array}$ \\
\hline $\begin{array}{l}\text { PACMANUS and } \\
\text { Susu Knolls }\end{array}$ & Manus Basin & T-ARC & Native $\mathrm{Au}(\leq 4 \mathrm{wt} \% \mathrm{Ag})$ & $\begin{array}{l}\text { Sphalerite, chalcopyrite and } \\
\text { barite, minor tennantite, } \\
\text { Pb-sulfosalts, bornite, } \\
\text { covellite, digenite, pyrite, } \\
\text { marcasite, and silica }\end{array}$ & $\begin{array}{l}\text { Native Au in high- and } \\
\text { low-temperature sulfide } \\
\text { assemblages, incl. } \\
\text { chalcopyrite, tennantite, } \\
\text { sphalerite, bornite, covellite, } \\
\text { and am. silica }\end{array}$ \\
\hline JADE & $\begin{array}{l}\text { Okinawa } \\
\text { Trough }\end{array}$ & T-ARC & $\begin{array}{l}\text { Native } \mathrm{Au} \text {, native } \mathrm{Ag} \text {, jalpaite } \\
\left(\mathrm{Ag}_{3} \mathrm{CuS}_{2}\right) \text { and } \\
\mathrm{Ag} \text {-bearing } \\
\text { tennantite/tetrahedrite } \\
\text { ( } \leq 2.5 \mathrm{wt} \% \mathrm{Ag}) \\
\mathrm{Ag} \text {-bearing galena (up to } \\
69 \mathrm{wt} \% \mathrm{Ag} \text { ) }\end{array}$ & $\begin{array}{l}\text { Chalcopyrite, pyrrhotite, pyrite, } \\
\text { sphalerite, galena, marcasite, } \\
\text { realgar, orpiment, } \\
\text { tennantite/tetrahedrite, barite, } \\
\text { and amorphous silica }\end{array}$ & $\begin{array}{l}\text { Native Au- and Ag-bearing } \\
\text { phases associated with } \\
\text { low-temperature barite and } \\
\text { sulfide minerals }\end{array}$ \\
\hline Franklin Seamount & $\begin{array}{l}\text { Woodlark } \\
\text { Basin }\end{array}$ & BAB-IO & $\begin{array}{l}\text { Native } \mathrm{Ag} \text {, electrum, } \\
\text { pyrargyrite }\left(\mathrm{Ag}_{3} \mathrm{SbS}_{3}\right), \\
\text { unknown } \mathrm{Ag}-\mathrm{Sb}-\mathrm{Pb} \\
\text { sulfosalt phase }\end{array}$ & $\begin{array}{l}\text { Pyrite, sphalerite, galena, and } \\
\text { chalcopyrite, minor } \\
\text { amorphous silica, and } \\
\text { cerrusite }\end{array}$ & $\begin{array}{l}\text { Electrum in interstices of pyrite, } \\
\text { am. silica and barite; } \\
\text { pyrargyrite in growth zones } \\
\text { and unknown Ag-phase as } \\
\text { inclusions within pyrite }\end{array}$ \\
\hline $\begin{array}{l}\text { Valu Fa Ridge (incl. } \\
\text { White Church, } \\
\text { Vai Lili \& Hine } \\
\text { Hina) }\end{array}$ & Lau Basin & BAB-IO & Native Au & $\begin{array}{l}\text { Sphalerite, minor barite, } \\
\text { chalcopyrite, bornite, } \\
\text { tennantite, galena, pyrite, } \\
\mathrm{Pb} \text {-As sulfosalts, and } \\
\text { amorphous silica }\end{array}$ & $\begin{array}{l}\text { Native } \mathrm{Au} \text { as inclusions or } \\
\text { linings in/around sphalerite, } \\
\text { chalcopyrite, and tennantite }\end{array}$ \\
\hline $\begin{array}{l}\text { Conical Seamount } \\
\text { (epithermal } \\
\text { veins) }\end{array}$ & $\begin{array}{l}\text { Near Lihir } \\
\text { island }\end{array}$ & $\begin{array}{l}\text { Alkaline } \\
\text { ARC }\end{array}$ & $\begin{array}{l}\text { Native } \mathrm{Au} \text {, electrum } \\
\quad(\leq 31 \mathrm{wt} \% \mathrm{Ag}) \\
\text { Ag-bearing tetrahedrite } \\
(\leq 18 \mathrm{wt} \% \mathrm{Ag})\end{array}$ & $\begin{array}{l}\text { Sphalerite, chalcopyrite, } \\
\text { tennantite-tetrahedrite, } \\
\text { galena, pyrite-marcasite, and } \\
\mathrm{Pb} \text {-sulfosalts }\end{array}$ & $\begin{array}{l}\text { Native Au and electrum as } \\
\text { intergrowths or in cavities } \\
\text { fills of sphalerite, galena, } \\
\text { rarely with chalcopyrite, } \\
\text { pyrite, and amorphous silica }\end{array}$ \\
\hline
\end{tabular}

References: Hannington et al. (1988), Halbach et al. (1993), Fouquet et al. (1993), Herzig et al. (1993), Hannington et al. (1995), Binns et al. (1997), Murphy and Meyer (1998), Moss and Scott (2001), Petersen et al. (2002), Lein et al. (2003), Ihle et al. (2005), Törmänen and Koski (2005), Mozgova et al. (2008), Melekestseva et al. (2010), Berkenbosch et al. (2012), Ye et al. (2012), Fouquet et al. (2013), Firstova et al. (2016), Wu et al. (2016), Melekestseva et al. (2017), Webber et al. (2017) and Iizasa et al. (2018) 
volcanic eruptions and/or mixed into the seafloor hydrothermal systems. Others have suggested that precious metal deposition may be bacterially mediated (Zierenberg and Schiffman 1990). And, in the metalliferous muds of the Atlantis II Deep, gold is thought to occur mainly in ultrafine arsenian pyrite, as well as adsorbed onto clay minerals from Au-enriched pore fluids (Laurila et al. 2015).

Tellurides that contain $\mathrm{Au}$ and $\mathrm{Ag}$, such as calaverite and hessite, and especially Bi-tellurides and sulfides in association with gold, have been reported from deposits in the summit calderas of several arc volcanoes (e.g., Monecke et al. 2016). The occurrence of specular hematite and $\mathrm{Au}-$ and $\mathrm{Bi}-$ tellurides in chalcopyrite from the Brothers volcano are consistent with direct magmatic contributions at this site (Berkenbosch et al. 2012). However, discrete $\mathrm{Bi}$ and $\mathrm{Te}$ minerals also have been documented in Au-bearing massive sulfides at Semyenov-2 and in the Escanaba Trough, indicating that co-enrichments of $\mathrm{Au}$, $\mathrm{Bi}$, and $\mathrm{Te}$ are not exclusively associated with felsic magmatic sources as previously noted by many authors. Törmänen and Koski (2005) proposed that traces of $\mathrm{Au}$ in the sulfide chimneys at Escanaba Trough were deposited because of their strong affinity to Bi metal, forming the $\mathrm{Au}-\mathrm{Bi}$ alloy, maldonite.

Gold and Ag are widely reported as trace constituents of sulfide minerals, either as solid solution in the host crystals or as submicroscopic inclusions, especially in chalcopyrite, pyrite, isocubanite, sphalerite, chalcocite, and covellite (Melekestseva et al. 2014, 2017; Wohlgemuth-Ueberwasser et al. 2015; Keith et al. 2016; Wang et al. 2017).

\section{Sources of gold and gold-bearing hydrothermal fluids}

Leaching of primary sulfides and the destruction of ferromagnesian minerals in basalt are the major sources of metals and sulfur in mid-ocean ridge hydrothermal systems (Hannington et al. 2005). Black smoker fluids at mid-ocean ridges have in situ $\mathrm{pH}$ values from of 4 to 5 , salinities of $<1$ to $8 \mathrm{wt} \% \mathrm{NaCl}$ equivalent (avg. 3.5, close to seawater), $\mathrm{CO}_{2}$ concentrations of $<5$ to $285 \mathrm{mmol}$ (avg. 40), $\mathrm{H}_{2} \mathrm{~S}$ concentrations of $<0.1$ to $41 \mathrm{mmol}$ (avg. 7.3), $\mathrm{H}_{2}$ concentrations of $<0.1$ to $1.8 \mathrm{mmol}$ (avg. 0.2), and total metal contents of $<10$ to $1300 \mathrm{ppm}$ (avg. 290) (Hannington et al. 2005). The narrow range of $\mathrm{H}_{2}$ and $\mathrm{H}_{2} \mathrm{~S}$ concentrations reflects equilibrium with a buffer assemblage including immiscible sulfides and Fe-bearing olivine in the most reduced systems and a greenschist alteration assemblage of pyrite-magnetite-anhydrite-calcic plagioclase-epidote in the most oxidized systems (Seyfried Jr et al. 1991; Seyfried Jr and Ding 1995). Dissolved sulfur concentrations are almost always in excess of dissolved metals. In ultramafic rocks, a number of different reactions can lead to low $\mathrm{pH}$ and metal-rich fluids, or alternatively high-pH and metal-depleted fluids over a wide range of temperatures (Wetzel and Shock 2000; Allen and Seyfried Jr 2003). High concentrations of $\mathrm{H}_{2}$ that can reach up to $16 \mathrm{mmol}$ are produced by serpentinization reactions through oxidation of ferrous iron in olivine:

$$
\begin{aligned}
& 15 \mathrm{Mg}_{2} \mathrm{SiO}_{4}+3 \mathrm{Fe}_{2} \mathrm{SiO}_{4}+23 \mathrm{H}_{2} \mathrm{O} \\
& \quad=9 \mathrm{Mg}_{3} \mathrm{Si}_{2} \mathrm{O}_{5}(\mathrm{OH})_{4}+3 \mathrm{Mg}(\mathrm{OH})_{2}+2 \mathrm{Fe}_{3} \mathrm{O}_{4}+2 \mathrm{H}_{2}
\end{aligned}
$$

Abundant $\mathrm{CH}_{4}$ is also produced during serpentinization, through a series of Fisher-Tropsch-like reactions that convert carbon dioxide to $\mathrm{CH}_{4}$ (Kelley and Früh-Green 1999; Früh-Green et al. 2004). In sediment-dominated environments, the fluids are often depleted in metals and enriched in the alkalies, ammonia, and organic-derived hydrocarbons relative to seawater-basalt systems. Chemical buffering by the sediment results in generally higher $\mathrm{pH}$ and more reduced hydrothermal fluids. Pyrrhotite tends to be the dominant $\mathrm{Fe}$-sulfide phase, and other minerals formed at low $f \mathrm{O}_{2}$ (e.g., Fe-rich sphalerite: Barton and Toulmin 1966) are commonly present. The lower venting temperatures compared to sediment-free mid-ocean ridges (e.g., $317{ }^{\circ} \mathrm{C}$ in the Guaymas Basin; $276{ }^{\circ} \mathrm{C}$ at Middle Valley; $217^{\circ} \mathrm{C}$ in the Escanaba Trough) and the higher $\mathrm{pH}$ account for the lower metal concentrations at the sea floor.

The major controls on vent fluid compositions in arc and back-arc settings are the same as those at mid-ocean ridges, but there is evidence that magmatic volatiles supply a number of components, including metals, to the hydrothermal fluids (Hannington et al. 1995). Endmember fluids commonly have higher concentrations of $\mathrm{K}$ and other alkali elements, reflecting the composition of the volcanic rocks, and they tend to be more oxidized because of the lower abundance of FeO-bearing minerals. Early observations of $\mathrm{Au}$ enrichment in the associated deposits could not be accounted for by differences in the $\mathrm{Au}$ contents of the source rocks and were mainly interpreted to reflect the oxidation state of the fluids (Herzig et al. 1993; Herzig and Hannington 1995). However, the role of magmatic volatiles in the enrichment of $\mathrm{Au}$ is now generally accepted, and the presence of isotopically distinct fluids in some anomalously Au-rich systems provides positive evidence for a direct magmatic contribution. For example, high concentrations of $\mathrm{Cu}, \mathrm{Fe}$, and $\mathrm{Zn}$ chlorides in a fluid phase co-existing with melt inclusions in andesite from the Eastern Manus Basin support the suggestion that metals may be contributed directly from the magma (Yang and Scott 1996; Kamenetsky et al. 2001; Yang and Scott 2002). 
Sampling black smoker fluids has produced a large dataset of several hundreds of analyses (German and Von Damm 2004). Yet, after more than three decades, only a few analyses of Au have been reported from just 10 locations, mostly within the last 6 years. This is partly because of the difficulty analyzing trace quantities of $\mathrm{Au}$ in the fluids, requiring difficult preconcentration techniques, but these difficulties have mostly been overcome. Early estimates based on analyses of the quenched products of high-temperature black smokers indicated Au concentrations in the end-member fluids of 0.05 to $0.2 \mathrm{ppb}$ (Hannington and Scott 1989a; Hannington et al. 1991a). Average value of $0.08 \mathrm{ppb} \mathrm{Au}$ used in this study is based on six references from mid-ocean ridge vents: $0.2 \mathrm{ppb} \mathrm{Au}$ from $21 \mathrm{~N}$ EPR black smoker fluids (Campbell et al. 1987), $0.1 \mathrm{ppb} \mathrm{Au}$ from the combined analysis of vent fluids and filtered particulates at Southern Explorer Ridge (Hall et al. 1988), 0.06 and $0.1 \mathrm{ppb}$ Au from analyses of quenched products of high-temperature vents from $21 \mathrm{~N}$ and $11 \mathrm{~N}$ EPR (Hannington and Scott 1989a; Hannington et al. 1991a), and $0.05 \mathrm{ppb}$ and $0.0074 \mathrm{ppb}$ $\mathrm{Au}$ in two samples from the Hanging Gardens vent at $21 \mathrm{~N}$ EPR (Falkner and Edmond 1990). The numbers were so low that many researchers considered it not worth the effort to pursue additional analyses. Then, gold concentrations in vent fluids from the Eastern Manus Basin and the Tonga arc were measured in the range of 0.6 to $1 \mathrm{ppb}$ (Table 5) a factor of $5 \times$ to $10 \times$ the MOR values (Craddock 2009; Gartman et al. 2018). These results seemed consistent with a probable felsic magmatic contribution to the hydrothermal fluids and were close to the reported concentrations of $\mathrm{Au}$ in land-based magmatichydrothermal systems, such as Broadlands and White Island (Simmons et al. 2016). But, the measured values were still much lower than in Au-rich magmatic fluids found in deep drill holes, for example, at Lihir (Simmons and Brown (2006): Table 5). In 2007, Hardardóttir et al. (2009) sampled the deep fluids at Reykjanes on Iceland, a seawater-dominated, basalthosted geothermal system on the Mid-Atlantic Ridge. $\mathrm{Au}$ concentrations in fluids collected below the boiling zone, at depths of $1500 \mathrm{~m}$, averaged $3 \mathrm{ppb}$ (up to $6 \mathrm{ppb}$ ). That experiment was repeated 7 years later, and $\mathrm{Au}$ concentrations in the same wells to $1650 \mathrm{~m}$ depth averaged $14.3 \mathrm{ppb} \mathrm{Au}$ (up to $21 \mathrm{ppb}$ : Hannington et al. (2016)), more than 2 orders of magnitude higher than the value for mid-ocean ridge black smoker fluids.

Considerable effort has gone into detecting parts per billion-level (and even sub-ppb) variations in the host rocks to try to explain the enrichment of $\mathrm{Au}$ in some systems. However, the reported range of $\mathrm{Au}$ concentrations in MORB, both bulk rock and glasses, is less than 1 up to $5 \mathrm{ppb}$ (Table 6). Ultramafic rocks have somewhat higher concentrations up to $8 \mathrm{ppb}$ (Table 6), and immiscible sulfides and mafic minerals could be an important source of $\mathrm{Cu}$ and $\mathrm{Au}$ for deposits in these settings (Pitcairn 2013; German et al. 2016). However, these differences do not appear to be large enough to account for the 2 to 3 orders of magnitude variation in the Au contents of the deposits. Webber et al. (2013) argued that substantial gold enrichment of oceanic crust during ridgeplume interaction could be a source for Au-rich SMS deposits. However, there are too few examples of deposits occurring where plumes impinge on MOR settings (Axial, Lucky Strike, Menez Gwen: Table 1) to say anything about the possibility that increased mantle melting at these locations has contributed to gold enrichment. High concentrations of $\mathrm{Au}$ have been reported in unaltered volcanic glass and glassy volcanic rocks from the Eastern Manus Basin, from $<1$ to $15 \mathrm{ppb}$ with an average of $6 \mathrm{ppb}$ (Moss and Scott 2001). Similar concentrations have been found in volcanic rocks from the arc front (Jenner et al. 2012; Park et al. 2015; Portnyagin et al. 2015: Table 6).

The low Au concentrations of sulfide deposits on sedimented ridges suggest generally low Au concentrations in the hydrothermal fluids, although these have never been measured. The metalliferous brines of the Red Sea may be an important exception, owing to the extremely high salinity originating from the dissolution of Miocene evaporite and reactions with a number of different rocks, including basalt and marine shale (Zierenberg and Shanks III 1986; Anschutz and Blanc 1995; Anschutz et al. 1995). Mass balance calculations for the brine pool suggest an end-member Au concentration in the brines of $0.26 \mathrm{ppb}$ (Laurila et al. 2015), close to that of hydrothermal brines from the Salton Sea (Table 5).

\section{Gold and silver solubility}

To examine the behavior of $\mathrm{Au}$ and $\mathrm{Ag}$ in different seafloor hydrothermal systems, we used the geochemical modeling software Geochemist's Workbench 12® (Bethke 2008). The aqueous and mineral species in the most recent version of the SUPCRT92 database (Johnson et al. 1992; Shock et al. 1997; Sverjensky et al. 1997) were entirely integrated into Geochemist's Workbench (GWB), using the software tool DBCreate (Kong et al. 2013), which generates the required file of equilibrium constants for GWB from the native format in SUPCRT92. The derived database was modified and extended by adding newer data for the aqueous and mineral species, especially for Au and Ag, from Akinfiev and Zotov (2001, 2010) and Pokrovski et al. (2014) (Table 1 in ESM 2). The B-dot equation, an extension of the Debye-Hückel equation (Helgeson 1969), was used to calculate activity coefficients for charged aqueous species. An activity coefficient of one was assumed for neutral aqueous species, except nonpolar 
Table 5 Measured Au concentrations in seafloor hydrothermal fluids and deep geothermal systems

\begin{tabular}{|c|c|c|c|c|c|c|c|c|}
\hline Location & Temp $\left({ }^{\circ} \mathrm{C}\right)$ & Depth (m) & Host rock & $\mathrm{Cu}(\mathrm{ppb})$ & $\mathrm{Zn}(\mathrm{ppb})$ & $\mathrm{Au}(\mathrm{ppb})$ & $\mathrm{Ag}(\mathrm{ppb})$ & Ref. \\
\hline MOR, e.g. EPR $(n=6)$ & 350 & $2500-2600$ & MORB & 1061 & 6735 & 0.08 & 4 & (1) \\
\hline BAB, Vienna Woods $(n=3)$ & 285 & 2485 & $\mathrm{BABB}$ & 286 & 1877 & $<0.02$ & 3 & $(2)$ \\
\hline Eastern Manus, SuSu $(n=11)$ & 325 & $1190-1500$ & Felsic & 14,616 & 3662 & 0.61 & 21 & (2) \\
\hline Eastern Manus, PAC $(n=13)$ & 358 & 1700 & Felsic & 16,774 & 39,589 & 0.94 & 43 & $(2)$ \\
\hline North Tonga, Niua $(n=10)$ & 325 & 1160 & Felsic & 3113 & 4157 & 1.05 & 4 & (3) \\
\hline Reykjanes $2007(n=3)$ & 314 & $1350-1400$ & MORB & 15,467 & 14,433 & 2.9 & 55 & (4) \\
\hline Reykjanes $2014(n=3)$ & 302 & $1575-1600$ & MORB & 2267 & 12,933 & 14.3 & 64 & $(5)$ \\
\hline Broadlands-Ohaaki & 290 & 1600 & Felsic & $<10$ & 330 & to 1.5 & to 8 & (6) \\
\hline White Island (vapor) & 345 & 0 & Felsic & 27 & 375 & 0.33 & 0.2 & (7) \\
\hline Ladolam Deep Fluid $(n=3)$ & $>275$ & $1350-1500$ & Felsic & 4450 & 185 & 16 & to 6 & $(8)$ \\
\hline Atlantis II Deep (calc.) & 350 & 2000 & Sediment & 2400 & 11,000 & 0.26 & 21 & (9) \\
\hline Salton Sea (wellhead) & 300 & $600-1070$ & Sediment & 2400 & 715,000 & to 0.6 & 90 & $(10)$ \\
\hline
\end{tabular}

Average of reported values unless indicated. References: 1 = Hannington et al. (2005); 2 = Craddock (2009); 3 = Gartman et al. (2018); 4 = Hardardóttir et al. (2009); 5 = Hannington et al. (2016); 6 = Brown (1986), Simmons et al. (2016); 7 = Hedenquist et al. (1993), Simmons et al. (2016) and references therein; 8 = Simmons and Brown (2006); $9=$ Laurila et al. (2014); $10=$ McKibben and Hardie (1997) and references therein

$M O R B=$ mid-ocean ridge basalt, $B A B B=$ back-arc basin basalt

species for which calculated activity coefficients were used (Drummond and Ohmoto 1985).

Calculated solubilities of Au and Ag for different aqueous complexes of the metals in the end-member fluids are shown in Fig. 7, under different buffer conditions corresponding to the range of volcanic and tectonic settings studied here: basalt-dominated mid-ocean ridges (MOR), ultramafic-dominated mid-ocean ridges (UM), volcanic arc and back-arc (ARC) settings, and sediment-dominated mid-ocean ridges (SED). The end-member fluid chemistry in each case is strongly influenced by the mineral assemblages present in the rocks, which largely control the $\mathrm{H}_{2}$ and $\mathrm{H}_{2} \mathrm{~S}$ activity. Fluids in ultramafic rock-dominated environments (UM) achieve highly reduced conditions close to the fayalite-magnetite-quartz (FMQ) buffer (Fig. 7a). In basalt-dominated MOR systems, the hydrothermal fluids are more oxidized, consistent with pyrite-pyrrhotite-magnetite (PPM) equilibrium (Fig. 7a). The highest oxidation

Table 6 Representative gold concentrations in volcanic and mafic plutonic rocks

\begin{tabular}{llll}
\hline Source & Location & Au (ppb) & Ref. \\
\hline Dunite, harzburgite & Hess Deep & 2.77 & Prichard et al. (1996) \\
Komatiite, picrite & Miscellaneous & $2-8$ & Keays (1987) \\
Icelandic basalt & Reykjanes & $0.2-4.2$ & Webber et al. (2013) \\
Hawaiian basalt & Kilauea & Global $(n=112)$ & Sisson (2003) \\
N-MORB & Mid-Atlantic Ridge & $1.5-3$ & Jenner and O'Neill (2012a, b) \\
N-MORB & Troodos & 1.45 & Keays and Scott (1976) \\
Basaltic andesite & Lau Basin & 0.97 & Patten et al. (2017) \\
Back-arc basalt & Manihiki Plateau & 2.1 & Jenner et al. (2012) \\
Low-Ti-basalt & Miscellaneous & 3.5 & Portnyagin et al. (2015) \\
Low-Ti-basalt & Tonga Arc & $3.8-5.2$ & Hamlyn et al. (1985) \\
Arc basalt-andesite & Etna (melt) & 0.87 & Park et al. (2015) \\
Arc basalt-andesite & Eastern Manus & $1.5-6.9$ & Botcharnikov et al. (2010) \\
Dacite-rhyolite & - & $1-8$ & Moss et al. (2001) \\
Continental crust & - & $<1-15$ & Taylor and McLennan (1985) \\
Continental crust & - & 3.0 & Rudnick and Gao (2014) \\
Primitive mantle & & 1.3 & Taylor and McLennan (1985) \\
\hline
\end{tabular}




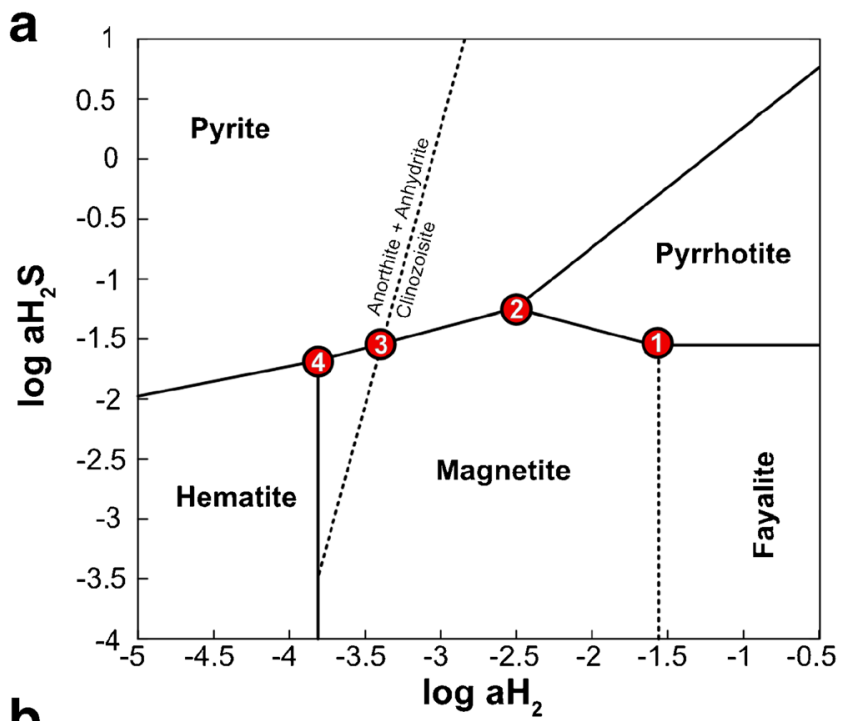

b
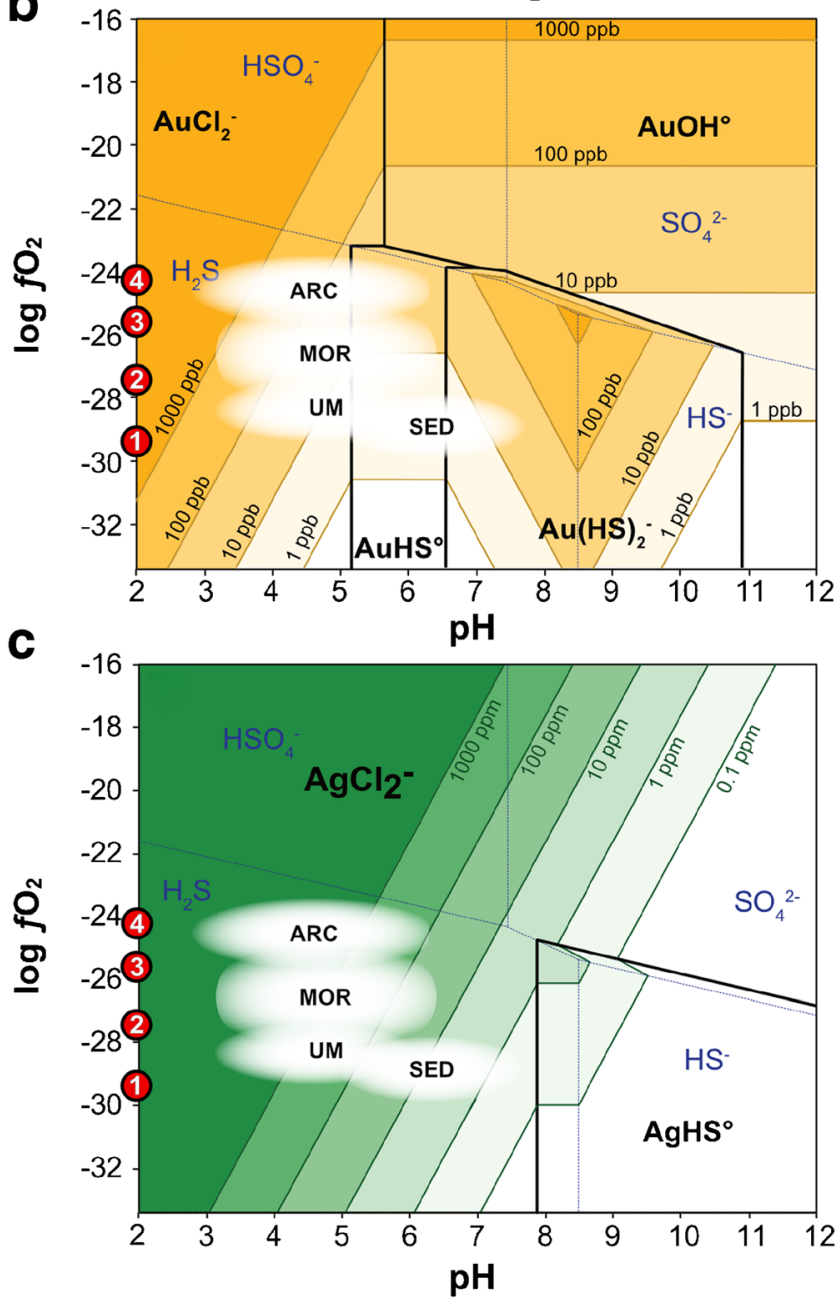

states are achieved by reaction with a "greenschist" mineral assemblage containing plagioclase, epidote, quartz, magnetite, anhydrite, and pyrite (PEQMAP buffer) as
Fig. 7 Phase diagrams of hydrothermal fluids under "reaction zone" conditions at $400{ }^{\circ} \mathrm{C}, 500$ bar, $0.5 \mathrm{~m} \mathrm{Cl}^{-}$(seawater) and quartz saturation. a $\log \mathrm{aH}_{2}-\log \mathrm{aH}_{2} \mathrm{~S}$ diagram showing the expected redox conditions for hydrothermal fluids buffered by the mineral assemblages present in the different rock buffers. The labeled red circles refer to the different buffering assemblages: (1) fayalite, magnetite and quartz (FMQ); (2) pyrite, pyrrhotite, and magnetite (PPM); (3) plagioclase, epidote, quartz, magnetite, anhydrite, and pyrite (PEQMAP); and (4) hematite, magnetite, and pyrite (HMP). b, c Fields of predominance of aqueous chloride, bisulfide, and hydroxide species of $\mathrm{Au}$ and $\mathrm{Ag}$ as functions of $\mathrm{pH}$ and $\log f \mathrm{O}_{2} . \Sigma \mathrm{S}$ is buffered by the assemblage of pyrite-pyrrhotite-magnetite. The yellow-shaded areas in $\mathbf{b}$ show the solubility contours for native gold from 1 to $1000 \mathrm{ppb}$; green shaded areas in $\mathbf{c}$ show the solubility contours for native silver from 0.1 to $1000 \mathrm{ppm}$. The labeled red circles refer to redox buffers in a expressed as $\log f \mathrm{O}_{2}$. The white-shaded ellipses indicate the approximate ranges of $\mathrm{pH}$ and $\log f \mathrm{O}_{2}$ for the corresponding fluids in mid-ocean ridge settings (MOR), ultramafic rock-hosted (UM), sediment-hosted s (SED), and arcrelated systems (ARC) (see text for discussion)

proposed by Seyfried Jr et al. (1999) and Seyfried and Ding (1995) (Fig. 7a):

$$
\begin{array}{r}
9 \mathrm{CaAl}_{2} \mathrm{Si}_{2} \mathrm{O}_{8}+0.5 \mathrm{Fe}_{3} \mathrm{O}_{4}+3 \mathrm{CaSO}_{4}+11 \mathrm{H}_{2} \\
=6 \mathrm{Ca}_{2} \mathrm{Al}_{3} \mathrm{Si}_{3} \mathrm{O}_{12}(\mathrm{OH})+1.5 \mathrm{FeS}_{2}+8 \mathrm{H}_{2} \mathrm{O}
\end{array}
$$

Modeled fluids in MOR systems range from reducing, with $\log \mathrm{H}_{2}$ activities as low as -1.5 , to less reducing, with $\log \mathrm{H}_{2}$ activities of -3.5 , and with equilibrium $\log$ $\mathrm{H}_{2} \mathrm{~S}$ activities in the range of -1.25 to -1.75 . In arcrelated (ARC) systems, where water reacts with volcanic rocks having even lower abundances of Fe-bearing minerals, the end-member hydrothermal fluids are typically more oxidized and approach hematite-magnetite-pyrite (HMP) equilibrium (Fig. 7a).

Figure $7 \mathrm{~b}$ shows the fields of predominance for chloride, bisulfide, and hydroxide aqueous species of $\mathrm{Au}$ under conditions where these different fluids develop. In hydrothermal fluids with low $\mathrm{pH}(<5), \mathrm{AuCl}_{2}{ }^{-}$is the dominant aqueous $\mathrm{Au}$ species. At intermediate $\mathrm{pH}$ (from 5 to 6.5), $\mathrm{AuHS}^{\circ}$ is dominant; at the highest $\mathrm{pH}(>6.5), \mathrm{Au}(\mathrm{HS})_{2}{ }^{-}$is the dominant $\mathrm{Au}$ species. Fluids typical of ARC environments have the highest potential to carry $\mathrm{Au}$, in the range of several parts per billion up to $100 \mathrm{ppb}$, whereas the solubility of gold is progressively lower in fluids from MOR, UM, and SED settings. Under the modeled conditions, it is clear that most of the seafloor hydrothermal fluids for which $\mathrm{Au}$ analyses are available (Table 5) would be undersaturated with gold. Figure $7 \mathrm{c}$ shows the results for silver. $\mathrm{AgCl}_{2}{ }^{-}$is the dominant aqueous $\mathrm{Ag}$ species in all of the modeled fluids, with maximum solubility at the lowest $\mathrm{pH}$ and highest oxidation states. Similar to the case of gold, all of the analyzed vent fluids are undersaturated with silver, and fluids typical of ARC environments are able to dissolve several hundreds to 
thousands of parts per million. The maximum possible $\mathrm{Au}$ and Ag solubilities for different rock buffers are plotted as functions of the fluid temperature and $\mathrm{pH}$ in Fig. 8. Under reservoir conditions $\left(\mathrm{pH}=4\right.$ to $\left.6,400{ }^{\circ} \mathrm{C}\right)$, the solubility of gold for the different buffers can span at least 1 order of magnitude (10 to $100 \mathrm{ppb}$, all species); the solubility of silver has a slightly smaller range (50 to $400 \mathrm{ppm}$, all species). Hydrothermal fluids that are buffered by crustal rocks (e.g., HMP buffer) have the greatest capacity to transport $\mathrm{Au}$ and $\mathrm{Ag}$.

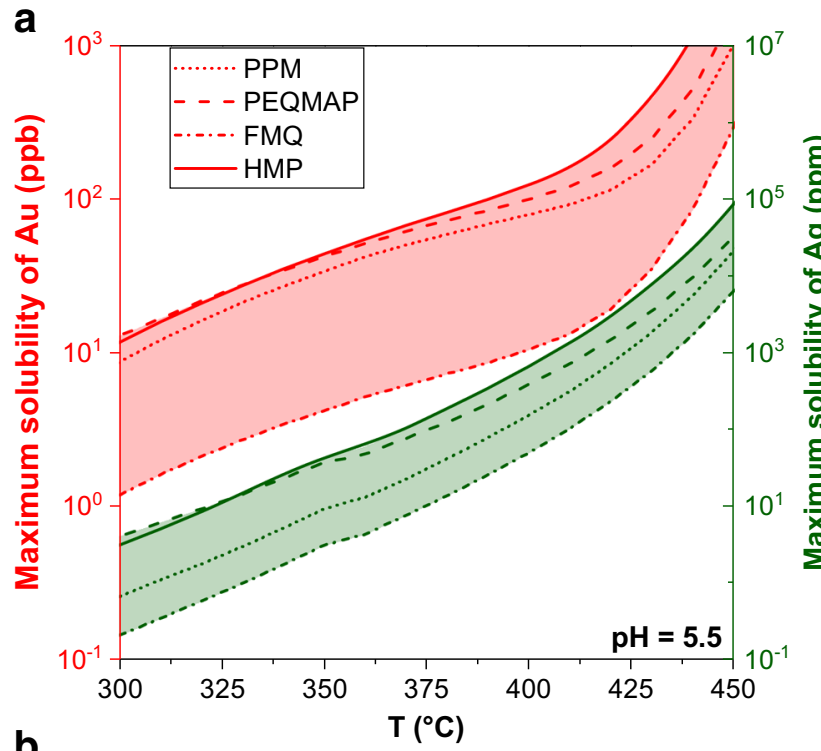

b

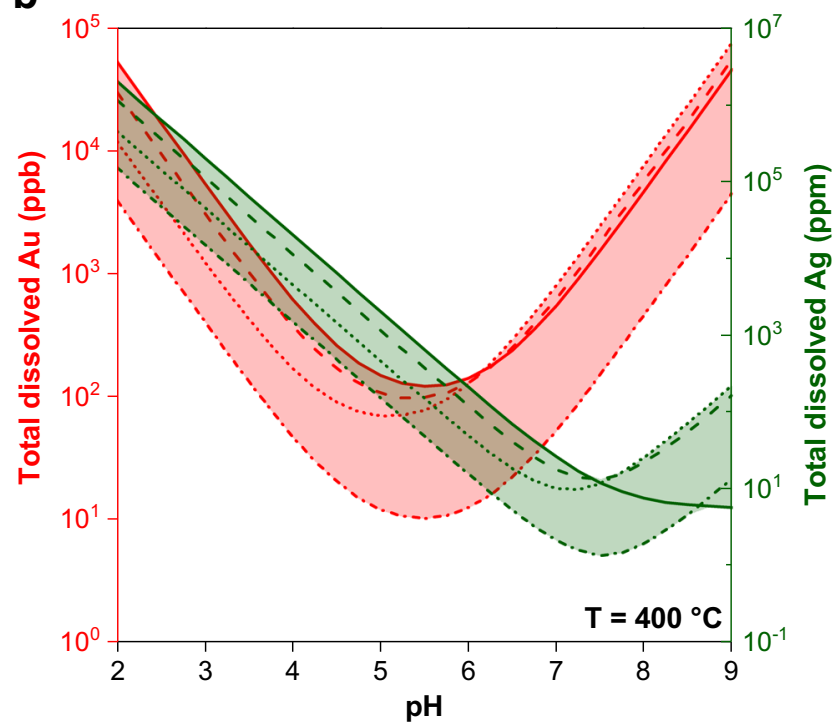

Fig. 8 Solubility of gold and silver in hydrothermal fluids under reservoir conditions as a function of $\mathbf{a}$ temperature and $\mathbf{b} \mathrm{pH}$. The different lines (red for $\mathrm{Au}$, green for $\mathrm{Ag}$ ) reflect the solubilities for different fluid buffers, corresponding to PPM (pyrite-pyrrhotite-magnetite) and PEQMAP (plagioclase-epidote-quartz-magnetite-anhydrite-pyrite) in basaltic rocks (dashed and dotted lines), FMQ (fayalite-magnetite-quartz) in ultramafic rocks (dash-dot line), and HMP (hematite-magnetite-pyrite) in felsic rocks (solid line). The mineral assemblages buffer the $\mathrm{H}_{2}$ and $\mathrm{H}_{2} \mathrm{~S}$ content of the fluid; a constant concentration $0.5 \mathrm{~m} \mathrm{Cl}^{-}$is assumed
Reaction-path modeling of gold precipitation

To investigate processes leading to the deposition of gold in different Au-rich mineral assemblages, we consider the behavior of aqueous Au complexes in a range of hydrothermal fluids equilibrated with different buffer assemblages and conditions of mineralization. A number of tools exist to model gold precipitation from dilute hydrothermal fluids. Reed (1982) first developed the CHILLER program, with aqueous speciation derived from SOLVEQ, to calculate heterogeneous equilibrium in cooling hydrothermal fluids and during mixing (Reed and Spycher 1984; Reed and Spycher 1985; Reed 1998; Reed and Palandri 2006). Several attempts have been made to model gold precipitation from seafloor hydrothermal fluids using GWB. In almost all cases, gold (and silver) precipitate at very low temperatures, owing to the high solubilities in the modeled fluids and the low $\mathrm{Au}$ concentrations assumed for the end-members. Most recently, Webber et al. (2017) used GWB to model precipitation of gold in the Beebe hydrothermal field under conditions buffered by pyrite-pyrrhotite equilibrium and assuming an end-member concentration of $0.1 \mathrm{ppb}$ Au. Gold saturation in their models occurred at $140{ }^{\circ} \mathrm{C}$ for conductive cooling and at $125^{\circ} \mathrm{C}$ for mixing. In models where the fluid was not buffered, gold did not precipitate until temperatures reached $30-40{ }^{\circ} \mathrm{C}$. These results are inconsistent with the observed enrichment of $\mathrm{Au}$ in polymetallic $\mathrm{Zn}$-rich and $\mathrm{Cu}$-rich assemblages typically formed at much higher temperatures. New data from a number of different seafloor hydrothermal systems suggest that $\mathrm{Au}$ concentrations in some end-member fluids may be significantly higher than previously thought (Table 5), allowing for gold precipitation at much higher temperatures.

In this study, two types of reaction paths were calculated using the REACT module of GWB: (i) conductive cooling and (ii) hydrothermal fluid-seawater mixing. Representative vent fluid compositions from each of the four buffer assemblages were modeled (Table 2 in ESM 2). Hydrothermal fluids from the Snakepit (MARK) and Rainbow vent fields, both located at the Mid-Atlantic Ridge, were chosen as typical of basalt-dominated (MOR) and ultramafic rock-dominated (UM) systems, respectively. A hydrothermal fluid from the Guaymas Basin in the Gulf of California was selected as an example of a sediment-dominated system (SED), in which typical MOR fluids have reacted with organic-rich, reducing sediments. An $\mathrm{Au}-\mathrm{Ag}$-bearing fluid from the Pacmanus site (Rogers Ruins) in the Manus Basin was chosen to represent an arc-related system (ARC) dominated by felsic volcanic rocks. All are seawater-dominated systems; fluids typical of magmatically degassing volcanoes at the volcanic fronts of arcs (e.g., Suiyo Seamount) were not modeled because of uncertainties in the fluid compositions and because the hydrothermal products in many cases more closely resemble highsulfidation epithermal systems than typical seafloor massive 
sulfide deposits. The $\mathrm{pH}$ values of the hydrothermal fluids, all measured at $25^{\circ} \mathrm{C}$, were back-calculated to the initial reservoir temperatures; the $\mathrm{pH}$ in the Guaymas Basin model, which is strongly buffered by reaction with sediments, was fixed at 5.9 (Von Damm 1990; Von Damm et al. 2006). The average $\mathrm{Au}$ concentration for mid-ocean ridge vent fluids $(0.08 \mathrm{ppb}=$ $0.41 \mathrm{nmol} \mathrm{Au}$ : Table 2 in ESM 2) was used initially for the calculations of MOR, UM, and SED systems. Conductive cooling was modeled in a closed system in which temperature was lowered in steps from 350 down to $<25{ }^{\circ} \mathrm{C}$. Hydrothermal fluid-seawater mixing was modeled by titrating cold seawater into the hydrothermal end-member until fluid temperatures reached $<25{ }^{\circ} \mathrm{C}$. Precipitated minerals were permitted to back-react over the entire model path.
The simple conductive cooling models illustrate the sensitivity of gold and silver deposition to the original rock buffer. The reaction path for a MOR vent fluid (Snakepit) is shown in Fig. 9, with temperature decreasing from reservoir conditions to an ambient temperature of $2{ }^{\circ} \mathrm{C}$. AuHS ${ }^{\circ}$ is the dominant $\mathrm{Au}$ species at all temperatures above $200{ }^{\circ} \mathrm{C}$; at lower temperatures, $\mathrm{AuHS}_{2}{ }^{-}$becomes dominant. The dominant Ag species at temperatures from 341 to $215^{\circ} \mathrm{C}_{\text {is }} \mathrm{AgCl}_{2}{ }^{-}$; at lower temperatures, $\mathrm{AgHS}^{\circ}$ becomes dominant. The calculated maximum solubilities at reservoir temperature for gold and silver are $4.5 \mathrm{ppb}$ and $14.7 \mathrm{ppm}$, respectively. The modeled fluid is highly undersaturated with respect to gold and silver, assuming the average concentrations in MOR vent fluids noted above, and only achieves saturation late in the cooling
Fig. 9 Geochemical reaction-path model for conductive cooling of a typical mid-ocean ridge (MOR) vent fluid from $341^{\circ} \mathrm{C}$ to ambient seawater temperature, represented by fluid samples from the Snakepit hydrothermal field on the Mid-Atlantic Ridge (Table 2 in ESM 2). a, b The concentrations of the $\mathrm{Au}$ and $\mathrm{Ag}$ species, respectively. The blackdashed lines correspond to the starting concentrations of $\mathrm{Au}$ and $\mathrm{Ag}$ in the modeled fluid from Table 2 in ESM 2; the gray-dotted correspond to the maximum solubility over the reaction path. c The minerals that precipitate upon cooling of a fluid with a starting concentration of $0.1 \mathrm{ppb}$ $(0.41 \mathrm{nmol}) \mathrm{Au}$ and the resulting $\mathrm{Zn}-\mathrm{Au}$ association at low temperatures. $\mathbf{d}$ The minerals that precipitate upon cooling of a fluid with a starting concentration of $1 \mathrm{ppb} \mathrm{Au}$ and the resulting $\mathrm{Cu}-$ $\mathrm{Au}$ association at much higher temperatures
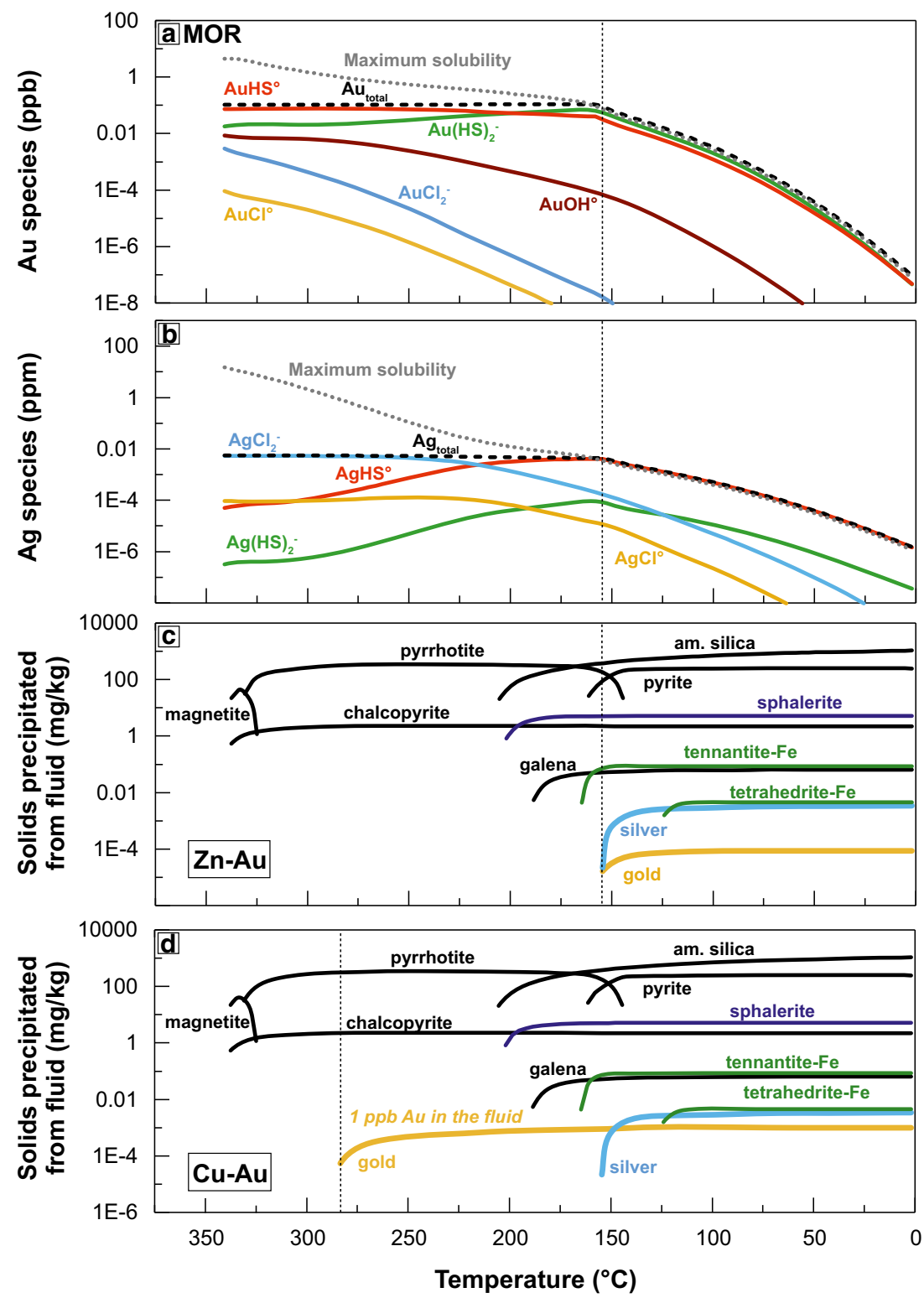


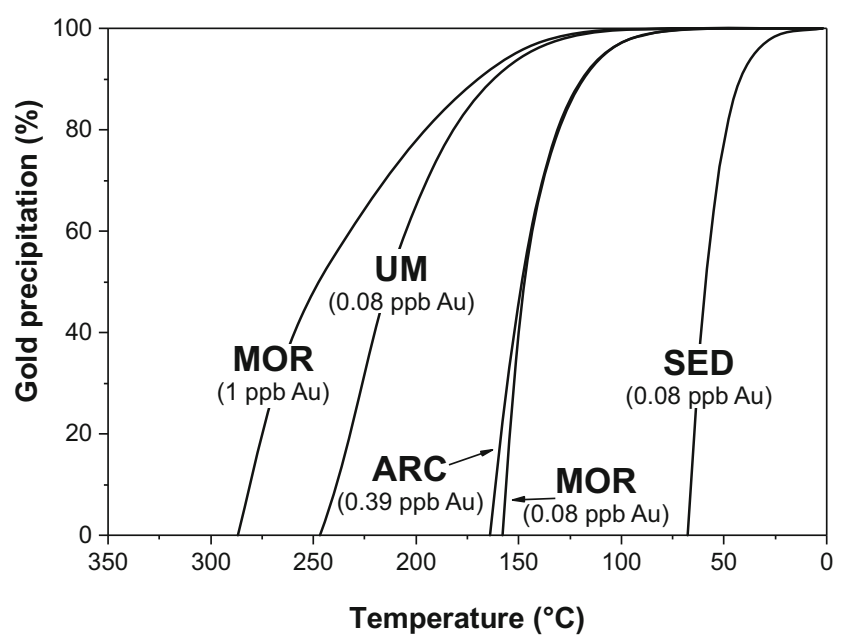

Fig. 10 Efficiency of gold deposition during conductive cooling of the four different vent fluids in the corresponding geological environments (MOR, UM, SED, ARC). The MOR fluid with initial Au concentration of $1 \mathrm{ppb}$ is also included. Gold precipitation at low temperatures $(0.1 \mathrm{ppb} \mathrm{Au}$ in the starting fluid) is very rapid, with $>90 \%$ of the gold deposited in the first $25{ }^{\circ} \mathrm{C}$ of cooling below $150{ }^{\circ} \mathrm{C}$. At higher concentrations of $\mathrm{Au}$, deposition begins at $>250{ }^{\circ} \mathrm{C}$ and is slower, requiring $100{ }^{\circ} \mathrm{C}$ of cooling to deposit $>90 \%$ of the gold

process. Both native gold and silver start to precipitate at $155{ }^{\circ} \mathrm{C}$ in a low-temperature sulfide mineral assemblage of sphalerite, tennantite- $(\mathrm{Fe}, \mathrm{Zn})$, tetrahedrite- $(\mathrm{Fe}, \mathrm{Zn})$, and galena. Gold precipitation begins after the start of sphalerite deposition and is very rapid, with $>90 \%$ of the gold deposited in the first $25^{\circ} \mathrm{C}$ of cooling below $150{ }^{\circ} \mathrm{C}$ (Fig. 10). The same cooling model was also run with an initial concentration of $1 \mathrm{ppb} \mathrm{Au}$. In this case, gold starts to precipitate at much higher temperatures $\left(283^{\circ} \mathrm{C}\right.$ : Fig. $\left.9 \mathrm{~d}\right)$ in a sulfide mineral assemblage dominated by chalcopyrite and pyrrhotite.

The reaction path for an ultramafic-hosted system (Rainbow) is strongly influenced by the high $\mathrm{H}_{2}$ concentration ( $\log \mathrm{aH}_{2}=-1.61$ ), compared to normal MOR fluids (Fig. 11). At temperatures from 362 to $335^{\circ} \mathrm{C}, \mathrm{AuCl}_{2}{ }^{-}$is the dominant Au species; at lower temperatures, $\mathrm{AuHS}^{\circ}$ becomes dominant. $\mathrm{AgCl}_{2}{ }^{-}$is the dominant $\mathrm{Ag}$ species until $146^{\circ} \mathrm{C}$ when $\mathrm{AgHS}{ }^{\circ}$ becomes dominant. The solubilities of gold and silver are generally very low, reflecting the reducing conditions, and reach a maximum of $2.36 \mathrm{ppb} \mathrm{Au}$ and $88.9 \mathrm{ppm} \mathrm{Ag}$ in the model fluid. As a result, the saturation of gold is achieved at a higher temperature than in the MOR model fluid, and the deposition of gold occurs with chalcopyrite in a $\mathrm{Cu}-\mathrm{Au}$-rich assemblage (Murphy and Meyer 1998). The low pH of the fluid causes a higher solubility for Ag, which precipitates after gold at $178{ }^{\circ} \mathrm{C}$. Because the fluids are undersaturated in $\mathrm{Ag}$ when gold is precipitating, the native metal is likely to be of
Fig. 11 Geochemical reactionpath model for conductive cooling of a typical ultramafichosted (UM) vent fluid from $362{ }^{\circ} \mathrm{C}$ to ambient seawater temperature, represented by fluid samples from the Rainbow hydrothermal field on the MidAtlantic Ridge (Table 2 in ESM 2). a, b The concentrations of the $\mathrm{Au}$ and $\mathrm{Ag}$ species, respectively. The black-dashed lines correspond to the starting concentrations of $\mathrm{Au}$ and $\mathrm{Ag}$ in the modeled fluid from Table 2 in ESM 2; the gray-dotted correspond to the maximum solubility over the reaction path. c The minerals that precipitate upon cooling of a fluid with a starting concentration of $0.1 \mathrm{ppb}$ $(0.41 \mathrm{nmol}) \mathrm{Au}$ and the resulting $\mathrm{Cu}-\mathrm{Au}$ association. Note: Because there is no information available about the As concentrations in this vent fluid, the formation of tennantite-( $\mathrm{Fe}$,

$\mathrm{Zn})$ minerals cannot be considered in this model
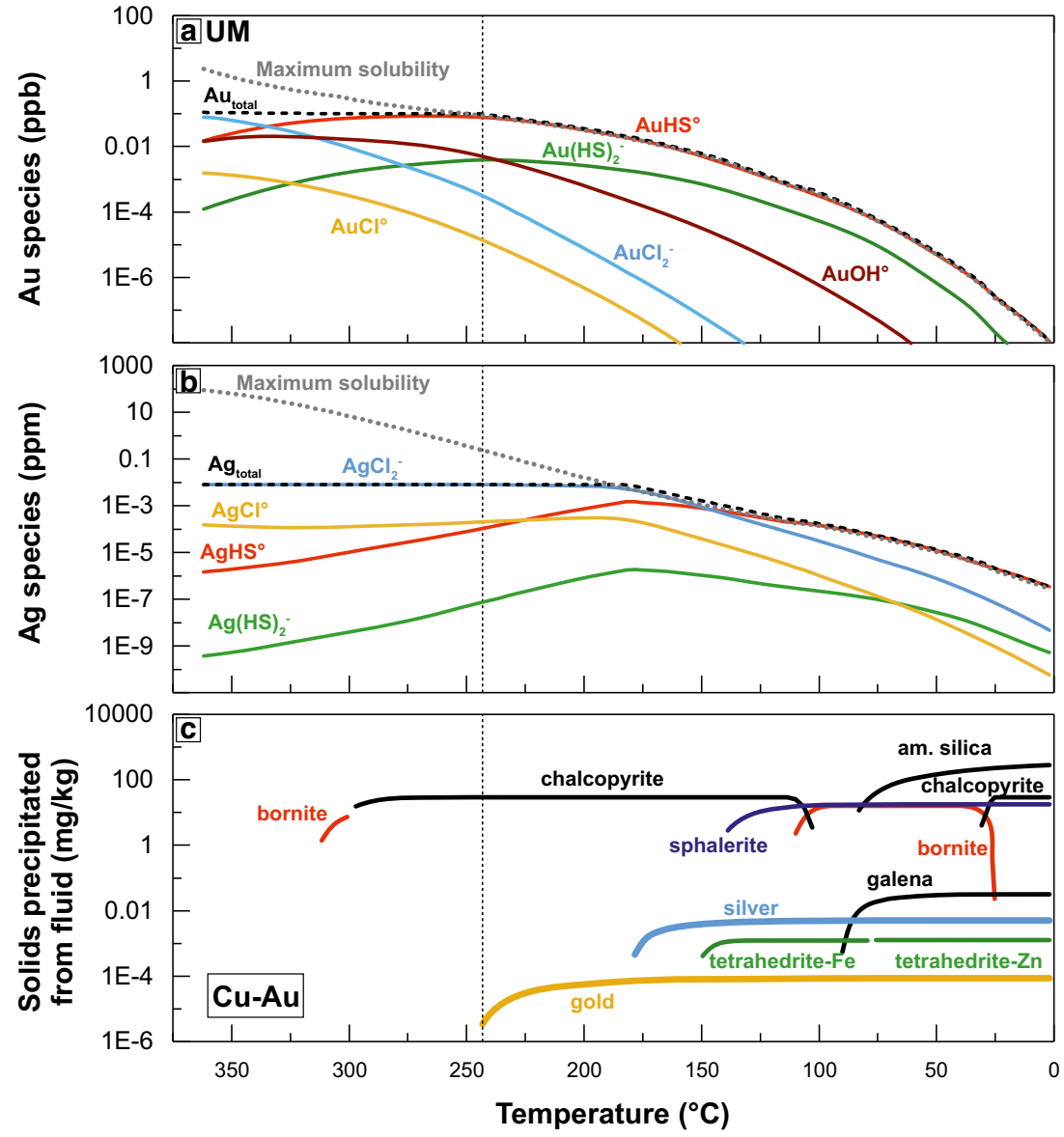
high fineness (Ag-poor), providing an explanation for the occurrence of mostly native gold rather than electrum in $\mathrm{Cu}$-rich chimneys of these deposits. A potentially important redox buffer in ultramafic rocks, not considered here, is $\mathrm{CO}_{2}-\mathrm{CH}_{4}$. Abiogenic methane production has been widely documented in ultramafic rock-hosted seafloor hydrothermal systems, a process that consumes $\mathrm{H}_{2}$ and $\mathrm{CO}_{2}$ in a Fischer-Tropsch-type reaction (Shock and Schulte 1998; Charlou et al. 2002; Shock and Canovas 2010; Hannington 2014). The lower $\mathrm{H}_{2}$ from this reaction has the potential to increase the solubility of both $\mathrm{Au}$ and $\mathrm{Ag}$, but this is likely offset by the production of $\mathrm{H}_{2}$ during serpentinization.

Mineral precipitation in the model for sedimented midocean ridge systems (SED) is strongly influenced by the higher $\mathrm{pH}$ compared to the other systems. $\mathrm{Au}(\mathrm{HS})_{2}{ }^{-}$is the dominant aqueous Au species over the entire cooling path (Fig. 12). The fluids dissolve slightly less silver than MOR fluids at $315^{\circ} \mathrm{C}$. At the initial stage of cooling, $\mathrm{AgCl}_{2}{ }^{-}$is dominant to $302^{\circ} \mathrm{C}$; at lower temperatures, $\mathrm{Ag}(\mathrm{HS})_{2}{ }^{-}$is dominant. At the maximum temperatures of the reservoir zone, the low $f \mathrm{O}_{2}$ of the fluids results in relatively low $\mathrm{Au}$ concentrations as $\mathrm{Au}(\mathrm{HS})_{2}{ }^{-}$(Fig. $7 b)$. However, the solubility in the cooling fluids reaches $25.1 \mathrm{ppb} \mathrm{Au}$ at $315{ }^{\circ} \mathrm{C}$ (vent temperature in the Guaymas
Basin: Fig. 12). In this case, the effect of the high $\mathrm{pH}$ on the stability of $\mathrm{Au}(\mathrm{HS})_{2}{ }^{-}$offsets the effect of the lower $f \mathrm{O}_{2}$. Because the high-pH fluids are able to transport $\mathrm{Au}$ at high concentrations within the stability field of $\mathrm{Au}(\mathrm{HS})_{2}{ }^{-}$, saturation with gold is only achieved at very low temperatures, well after deposition of most of the sulfides, resulting in a generally Aupoor polymetallic sulfide assemblage.

Vent fluids in volcanic arc settings (Roger Ruins model) are characterized by low $\mathrm{pH}$ (3.3) and very low $\mathrm{H}_{2}$ content (log $\mathrm{aH}_{2}=-4.98$ ), with high $\mathrm{Au}$ and $\mathrm{Ag}$ concentrations compared to MOR fluids (Fig. 13; Table 2 in ESM 2). We modeled cooling with an initial $\mathrm{Au}$ concentration of $2 \mathrm{nmol} / \mathrm{kg}$ ( $0.4 \mathrm{ppb}$ from Craddock 2010) compared to $0.41 \mathrm{nmol} / \mathrm{kg}$ for the MOR fluids (Table 2 in ESM 2). During conductive cooling from $320{ }^{\circ} \mathrm{C}$ to ambient temperature, $\mathrm{AuHS}^{\circ}$ is the dominant $\mathrm{Au}$ species. $\mathrm{AgCl}_{2}{ }^{-}$is the dominant $\mathrm{Ag}$ species down to $167{ }^{\circ} \mathrm{C}$; at lower temperatures, $\mathrm{AgHS}^{\circ}$ becomes dominant. Maximum solubilities in these oxidized fluids are $54 \mathrm{ppb} \mathrm{Au}$ and $2134 \mathrm{ppm} \mathrm{Ag}$ at reservoir temperatures. Gold saturation is reached after cooling to $161^{\circ} \mathrm{C}$; silver starts to precipitate below $142{ }^{\circ} \mathrm{C}$. Because of the higher initial Au concentration, gold deposition occurs at a slightly higher temperature than in the MOR model, together with chalcopyrite, sphalerite,
Fig. 12 Geochemical reactionpath model for conductive cooling of a typical sedimenthosted (SED) vent fluid from $315^{\circ} \mathrm{C}$ to ambient seawater temperature, represented by fluid samples from the Guaymas Basin (Table 2 in ESM 2). a, b The concentrations of the $\mathrm{Au}$ and $\mathrm{Ag}$ species, respectively. The blackdashed lines correspond to the starting concentrations of $\mathrm{Au}$ and $\mathrm{Ag}$ in the modeled fluid from Table 2 in ESM 2; the gray-dotted correspond to the maximum solubility over the reaction path. c The minerals that precipitate upon cooling of a fluid with a starting concentration of $0.1 \mathrm{ppb}$ $(0.41 \mathrm{nmol}) \mathrm{Au}$ and the resulting Au-poor polymetallic sulfide assemblage at very low temperatures. Note: Because there is no information available about the $\mathrm{Sb}$ concentrations in this vent fluid, the formation of tetrahedrite- $(\mathrm{Fe}, \mathrm{Zn})$ minerals cannot be considered in this model
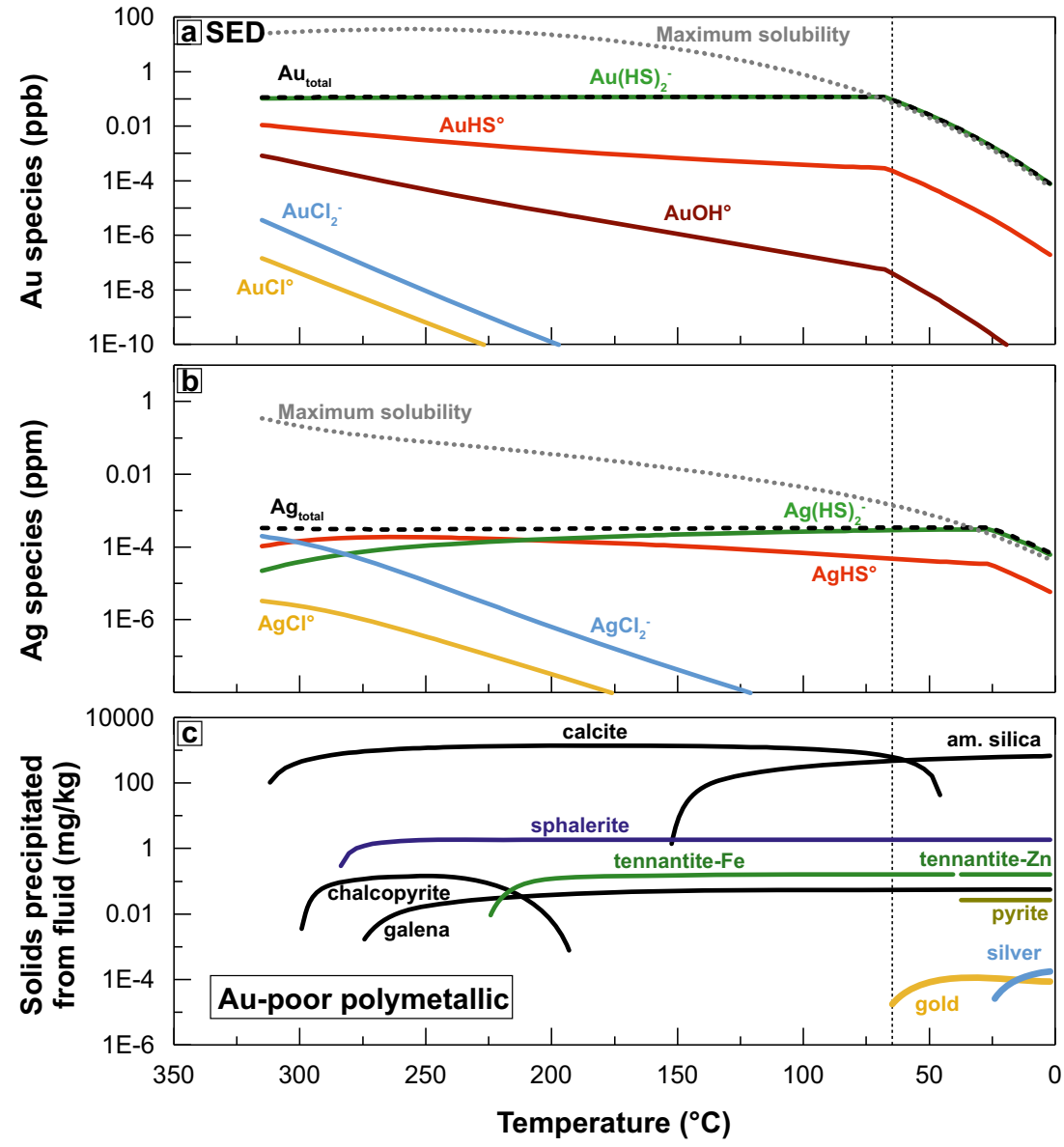
Fig. 13 Geochemical reactionpath model for conductive cooling of a typical arc-related (ARC) vent fluid from $320^{\circ} \mathrm{C}$ to ambient seawater temperature, represented by samples from the Roger's Ruins field at the Pacmanus site in the Eastern Manus Basin (Table 2 in ESM 2). a, b The concentrations of the $\mathrm{Au}$ and $\mathrm{Ag}$ species, respectively. The black-dashed lines correspond to the starting concentrations of $\mathrm{Au}$ and $\mathrm{Ag}$ in the modeled fluid from Table 2 in ESM 2; the gray-dotted correspond to the maximum solubility over the reaction path. c The minerals that precipitate upon cooling of a fluid with a starting concentration of $0.39 \mathrm{ppb}$ ( $2 \mathrm{nmol}) \mathrm{Au}$, reflecting the higher initial $\mathrm{Au}$ concentration of ARC fluids, and the resulting Au-rich polymetallic sulfide association
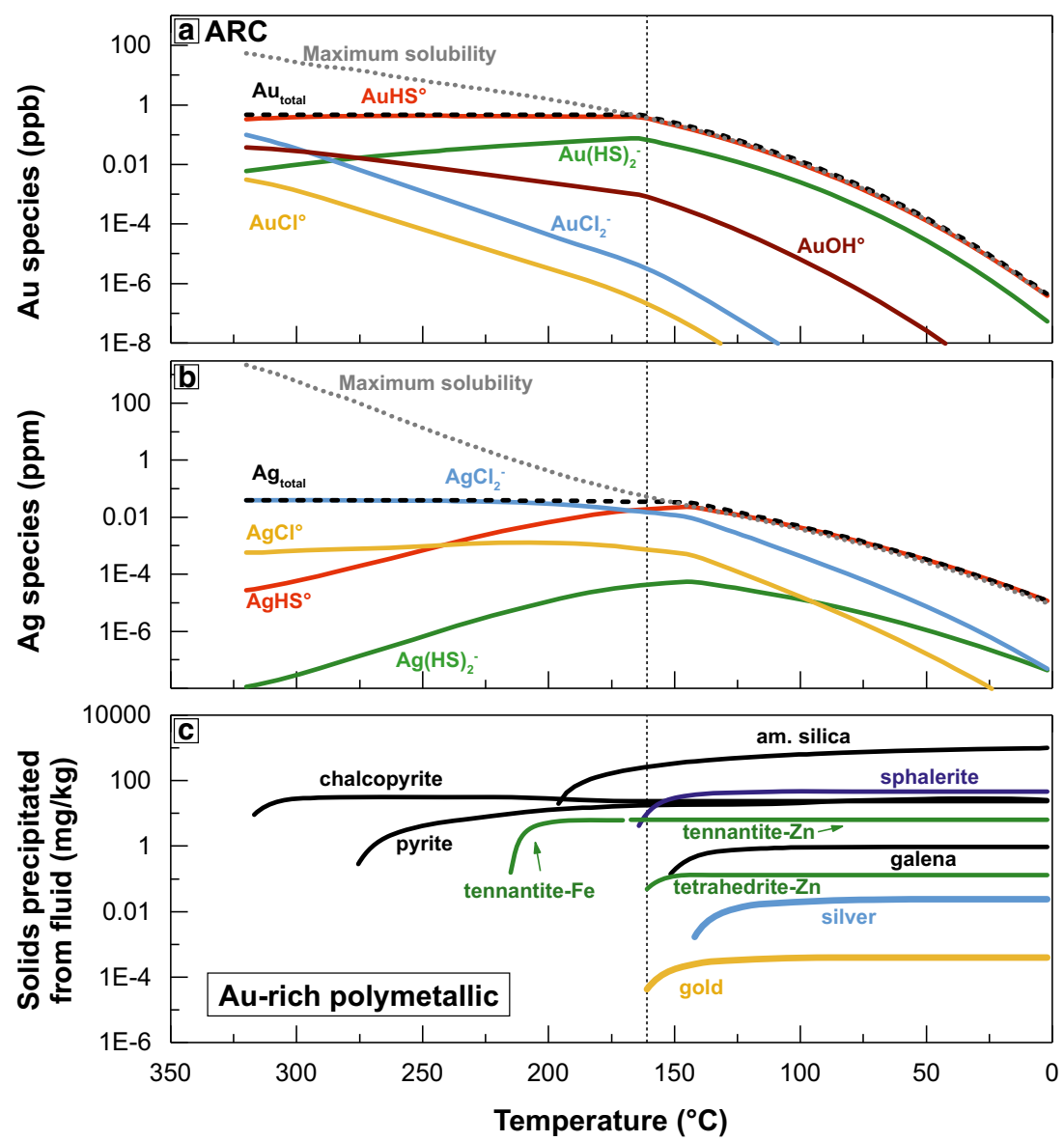

tennantite-(Fe, $\mathrm{Zn})$, and galena, resulting in an Au-rich polymetallic sulfide assemblage. Differences in the quantities of sulfosalts that are precipitated (e.g., in ARC versus MOR systems) reflect the concentrations of $\mathrm{As}$ and $\mathrm{Sb}$ in the modeled fluids (Table 2 in ESM 2). Because these fluids have an even higher starting concentration of $\mathrm{Au}$ (e.g., average of $4.8 \mathrm{ppb}=$ 0.94 nmol: Table 4), gold precipitation could have occurred at temperatures up to $100^{\circ} \mathrm{C}$ higher than indicated in Fig. 13.

Cooling of the MOR hydrothermal fluid to ambient temperature produced a total mineral mass of $1.36 \mathrm{~g}$ per $1 \mathrm{~kg}$ of fluid. Assuming quantitative deposition of the metal in the starting fluid, the resulting grades are $0.07 \mathrm{~g} / \mathrm{t} \mathrm{Au}$ and $2.55 \mathrm{~g} / \mathrm{t} \mathrm{Ag}$ in the precipitated massive sulfide. The hydrothermal fluids from the ultramafic model precipitated $0.35 \mathrm{~g} / \mathrm{kg}$ and yield $0.26 \mathrm{~g} / \mathrm{t} \mathrm{Au}$ and $15.0 \mathrm{~g} / \mathrm{t} \mathrm{Ag}$. The fluids in the sediment-dominated MOR model precipitated $0.72 \mathrm{~g} / \mathrm{kg}$ and yield $0.13 \mathrm{~g} / \mathrm{t} \mathrm{Au}$ and $0.3 \mathrm{~g} / \mathrm{t}$ $\mathrm{Ag}$. The arc-related fluids precipitated $1.13 \mathrm{~g} / \mathrm{kg}$ and yield $0.36 \mathrm{~g} / \mathrm{t} \mathrm{Au}$ and $22.27 \mathrm{~g} / \mathrm{t} \mathrm{Ag}$. Although the patterns of enrichment in the models are consistent with the grades of the deposits, the modeled grades are mostly 1-2 orders of magnitude lower than the reported median Au und Ag grades in the massive sulfides (Table 1). This may be due to a number of factors: (i) the $\mathrm{Au}$ concentrations in the fluids are higher than in the modeled fluids (Table 4), (ii) the sulfides have been upgraded by processes such as zone-refining, and/or (iii) the metals may accumulate in the deposits over time.

In Fig. 14, we simulate step-wise mixing between the hightemperature MOR vent fluid and cold seawater until a final temperature of $<25{ }^{\circ} \mathrm{C}$, corresponding to a final vent fluid to seawater ratio of 1:15. Mixing in the model begins at the initial venting temperature of $341^{\circ} \mathrm{C}$. At a mixing ratio of $1: 1$, there is a large increase in $\mathrm{SO}_{4}{ }^{2-}$, becoming the dominant aqueous sulfur species at $275{ }^{\circ} \mathrm{C}$. However, the relatively slow decrease of $\mathrm{H}_{2}$ and $\mathrm{H}_{2} \mathrm{~S}$ is explained by the limited amount of $\mathrm{O}_{2}$ supplied by the seawater, confirming earlier mixing models (Janecky and Shanks 1988). The maximum solubilities of gold and silver initially increase to $27.8 \mathrm{ppb}$ and $1736 \mathrm{ppm}$, respectively, at a temperature of about $296^{\circ} \mathrm{C}$ due to the small increase in $f \mathrm{O}_{2}$, and so gold and silver saturation is delayed. Native gold begins to precipitate at a temperature of $117^{\circ} \mathrm{C}$, and native silver at $76^{\circ} \mathrm{C}$, associated with a low-temperature sulfide mineral assemblage. Mixing in the ratio of $>100: 1$ would be needed to completely oxidize the hydrothermal fluids (Bethke 2008) and thereby cause quantitative deposition of gold. As a result of the large buffer capacity of the high-temperature fluids, and the production of additional $\mathrm{H}^{+}$during sulfide oxidation, the $\mathrm{pH}$ remains low (4.5) until $>2.25 \mathrm{~L}$ of seawater has been mixed with $1 \mathrm{~L}$ of the hydrothermal fluid (at $106{ }^{\circ} \mathrm{C}$ ). This further 
Fig. 14 Geochemical reactionpath model for mixing of a typical mid-ocean ridge (MOR) vent fluid with ambient seawater, using the starting composition of the Snakepit hydrothermal field on the Mid-Atlantic Ridge (Table 2 in ESM 2). This model assumes incremental mixing with cold seawater $\left(2{ }^{\circ} \mathrm{C}\right)$ until a final temperature $25^{\circ} \mathrm{C}$ (mixing ratio 1:15). a The mixing fraction of seawater into the hydrothermal fluid. $\mathbf{b}$ The concentrations of aqueous $\mathrm{H}_{2} \mathrm{~S}, \mathrm{H}_{2}$, and $\mathrm{SO}_{4}{ }^{2-}$ and the $\mathrm{pH}$ (right-hand axis) as a function of temperature. $\mathbf{c}$ The concentration of aqueous $\mathrm{Au}$ species. The black-dashed lines correspond to the starting concentrations of $\mathrm{Au}$ and $\mathrm{Ag}$ in the modeled fluid from Table 2 in ESM 2; the gray-dotted line correspond to the maximum solubility over the reaction path. $\mathbf{d}$ The minerals that precipitate with mixing and the resulting $\mathrm{Zn}-\mathrm{Au}$ association at low temperatures. The apparent decrease in the amount of minerals precipitated at low temperature is an artifact of the increasing mass of fluid in the model as a result of mixing

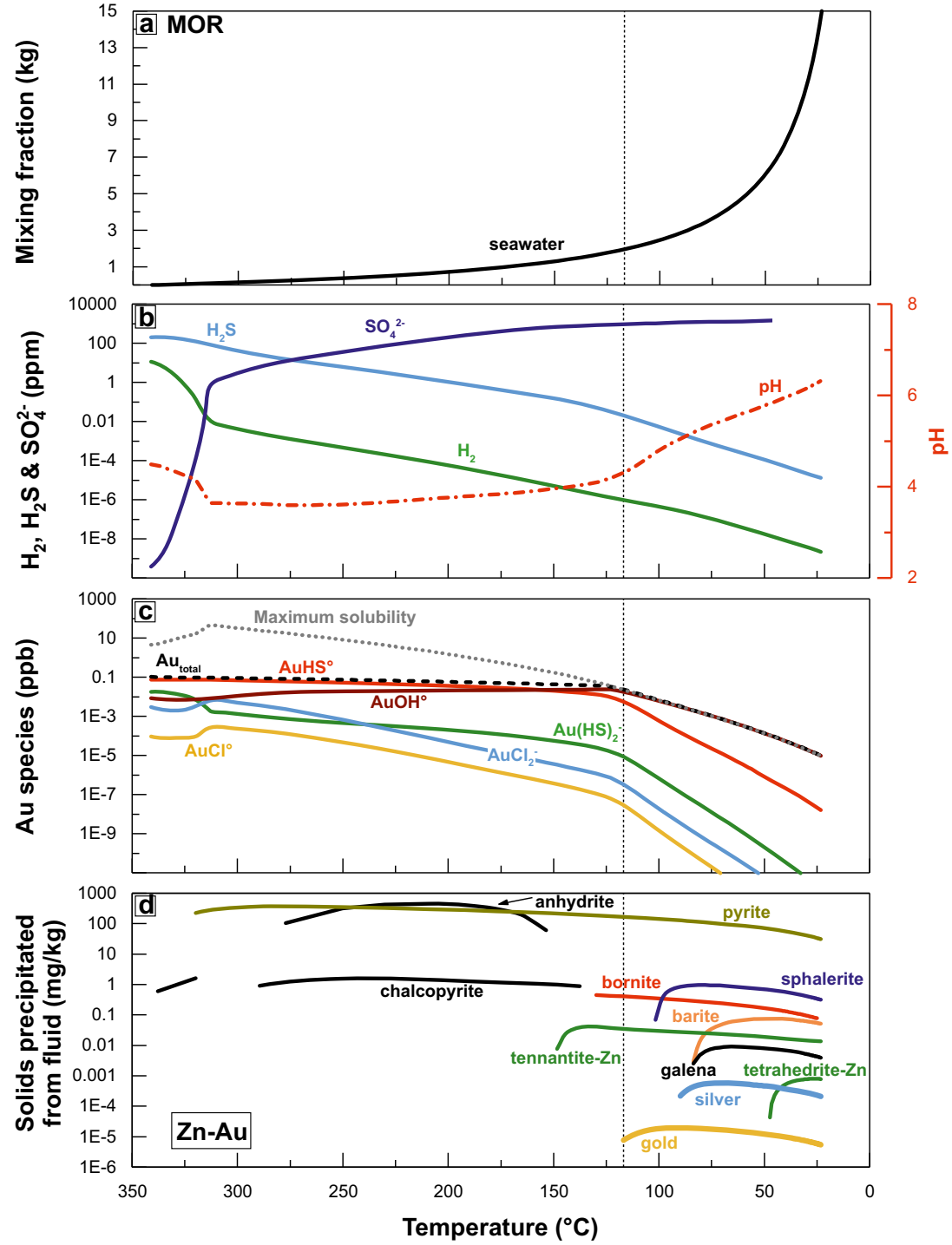

inhibits the precipitation of gold and some other minerals, such as sphalerite and barite, until low temperatures are reached. Similar results for mixing are observed for the ultramafic- and sediment-dominated systems, as well as the arc-related hydrothermal fluids (Figs. 2, 3, and 4 in ESM 2). In every case, the mixture causes oxidation by seawater increasing the solubility of $\mathrm{Au}$ and $\mathrm{Ag}$, which precipitate only at low temperatures $\left(<150{ }^{\circ} \mathrm{C}\right)$. Because of the high $\mathrm{pH}$ of the sedimentdominated (SED) system (Guaymas Basin), metal saturation and precipitation was not reached under the modeled conditions for mixing.

\section{Role of boiling}

The role of boiling as a means of gold deposition is becoming increasingly apparent in seafloor hydrothermal vents, as evidence for subcritical phase separation is found in a wide range of different settings (Hannington et al. 1999; Monecke et al. 2014). Boiling at or close to the seafloor was first documented at the relatively shallow Axial Volcano on the Juan de Fuca Ridge (1540 m and $348{ }^{\circ} \mathrm{C}$ : Massoth et al. 1989; Butterfield et al. 1990). At $1500 \mathrm{~m}$ water depth, the near-vertical adiabats of most fluids at $350{ }^{\circ} \mathrm{C}$ will intersect the two-phase boundary about $100 \mathrm{~m}$ below the seafloor, and the fluid will boil continuously from that depth as it rises to the seafloor. At these low pressures, the density difference between the vapor and liquid is large, resulting in the separation of a low-salinity, gasrich phase. The boiling temperatures range from a few hundred degrees at shallow water depths $(1000 \mathrm{~m})$ to more than $400{ }^{\circ} \mathrm{C}$ in the deepest vents. A compilation of measured vent temperatures in different settings, down to at least $3 \mathrm{~km}$ water depth, shows a range of temperatures in every vent field lying on a mixing line that terminates at or near the boiling curve (Fig. 15). The distribution of vent temperatures strongly suggests that the highest-temperature fluids in every system have 


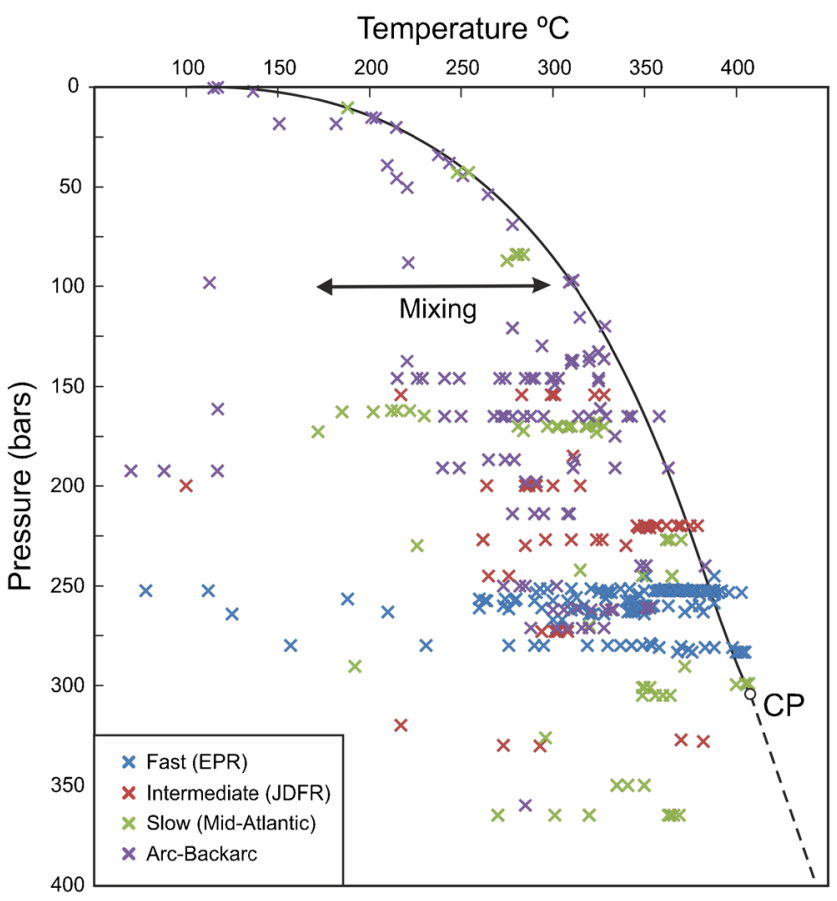

Fig. 15 Compilation of measured vent temperatures of modern seafloor hydrothermal systems plotted as function of pressure modified after Monecke et al. (2016). The boiling curve and critical point (CP) of seawater $(3.2 \mathrm{wt} \% \mathrm{NaCl})$ are taken from Driesner and Heinrich (2007)

boiled, and the phenomenon may be much more common than previously thought (Huston 2000). Because boiling is restricted to the hottest vents, a strong $\mathrm{Cu}-\mathrm{Au}$ enrichment may be expected in the associated chimneys, as observed in recent studies (Gartman et al. 2018). Unboiled fluids that have cooled by mixing with seawater before reaching the seafloor are more likely to produce a $\mathrm{Zn}-\mathrm{Au}$ association.

Exsolution of dissolved gases $\left(\mathrm{CO}_{2}, \mathrm{H}_{2}, \mathrm{H}_{2} \mathrm{~S}, \mathrm{SO}_{2}\right)$ into the vapor phase during boiling shifts both the $\mathrm{pH}$ and the redox phase equilibria, thereby strongly influencing Au solubility. These effects have been modeled by Drummond and Ohmoto (1985) and Reed and Spycher (1985). Critical for the precipitation of gold and silver is the fractionation of $\mathrm{H}_{2} \mathrm{~S}$ into the vapor phase, causing a decrease in the activity of $\mathrm{HS}^{-}$that destabilizes the dominant aqueous sulfur complexes, such as $\mathrm{AuHS}^{\circ}, \mathrm{Au}(\mathrm{HS})_{2}{ }^{-}$, and $\mathrm{AgHS}^{\circ}$. However, model outcomes vary because of the different starting concentrations used in different studies, from $0.1 \mathrm{ppb} \mathrm{Au}$ in Reed and Spycher (1985), and much higher concentrations (i.e., at saturation) in Drummond and Ohmoto (1985). Reed and Spycher $(1984,1985)$ employed a stepwise calculation to model isoenthalpic boiling, calculating the amount of mineral precipitated for each degree of temperature decrease along the $P-T$ curve. In their models, gold was not precipitated because of the low Au concentration of the fluid, and it was necessary to remove almost all of the aqueous sulfide to sulfide minerals and gas in order to reach saturation. In subsequent models for the Broadlands geothermal system, Spycher and Reed (1989) used a much higher Au concentration of $1.5 \mathrm{ppb}$ (Brown 1986) and showed that gold precipitates readily upon boiling at these high concentrations, depositing early relative to the base metal sulfides as a consequence of the low chloride concentrations of the fluids. Drummond and Ohmoto (1985) showed that the $\mathrm{pH}$ increases significantly during boiling when $\mathrm{H}^{+}<\mathrm{HCO}_{3}{ }^{-}$, as the destabilization of aqueous $\mathrm{HCO}_{3}{ }^{-}$ to produce $\mathrm{CO}_{2}$ consumes $\mathrm{H}^{+}$according to the reaction:

$\mathrm{HCO}_{3}{ }^{-}+\mathrm{H}^{+}=\mathrm{CO}_{2}+\mathrm{H}_{2} \mathrm{O}$

This promotes Au solubility in the initial stages of boiling, especially at high temperatures (Spycher and Reed 1989); however, at higher temperatures, the effect of the $\mathrm{pH}$ change is small, allowing gold to precipitate. Moreover, in fluids with initial concentrations of $\mathrm{H}^{+}>\mathrm{HCO}_{3}{ }^{-}$, as in most MOR vent fluids (Table 2 in ESM 2), the $\mathrm{pH}$ does not change significantly during boiling and decreases slightly as a result of the adiabatic cooling.

Figure 16 shows a model for incremental boiling of an $\mathrm{Au}-$ rich black smoker fluid, following the method of Drummond and Ohmoto (1985). The models for ultramafic-hosted, sediment-hosted, and arc-related fluids (UM, SED, ARC) are presented in Figs. 5, 6, and 7 in ESM 2. Boiling is simulated by combining the cooling model with the loss of volatile gas species from 350 to $200{ }^{\circ} \mathrm{C}$ in an isoenthalpic, open system. Gases are removed incrementally and the liquid reequilibrated in a stepwise manner until $100 \%$ of the fluid has boiled at $200{ }^{\circ} \mathrm{C}$. The partitioning of the gases between the liquid and vapor phase is calculated using the volatility ratios (VR), a measure of the affinity of a gas species for the vapor phase in a two-phase system defined as:

$\mathrm{VR}=m^{\text {vapor }} / m^{\text {liquid }}$

where $m^{\text {vapor }}$ and $m^{\text {liquid }}$ are the molality of volatile compounds in the respective phase. We derived values of VR by the methods of Drummond and Ohmoto (1985):

$\mathrm{VR}=K_{\mathrm{H}} V^{\mathrm{v}}{ }_{\mathrm{w}} / Z R T$

where $K_{\mathrm{H}}$ represents the fugacity/molality ratio of the volatile gas species, $V_{\mathrm{W}}^{\mathrm{v}}$ the specific volume of the water vapor, $Z$ the compressibility factor of the gas in the vapor phase, $R$ the gas constant, and $T$ the absolute temperature. The volatility ratios of the dissolved gases increase during cooling, which results in strong partitioning into the vapor according to: $\mathrm{H}_{2}>$ $\mathrm{CO}_{2}>\mathrm{H}_{2} \mathrm{~S}>\mathrm{SO}_{2}$.

At the beginning of boiling, $\mathrm{AuHS}^{\circ}$ is the dominant aqueous $\mathrm{Au}$ species, and $\mathrm{AuOH}^{\circ}$ becomes more important with progressive boiling and cooling due to the loss of $\mathrm{H}_{2} \mathrm{~S}$ and 


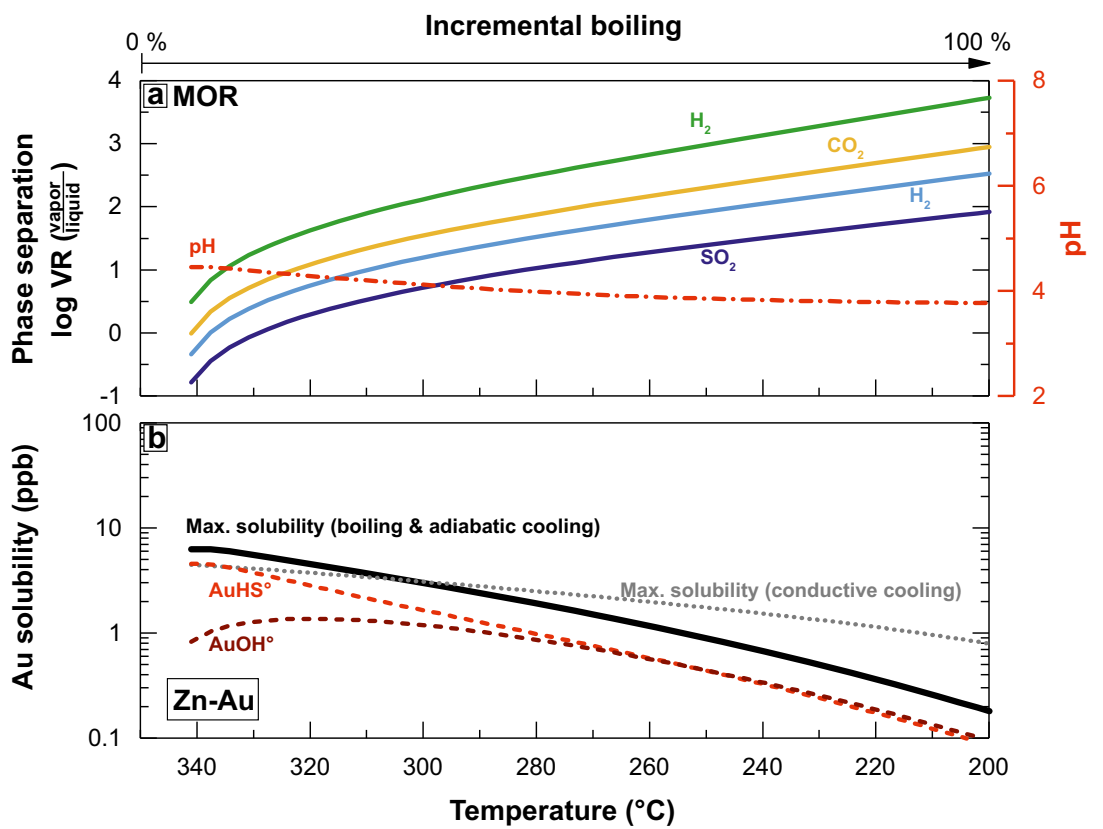

Fig. 16 Model simulation of isoenthalpic boiling in an open system and associated adiabatic cooling of a typical mid-ocean ridge (MOR) vent fluid (Table 2 in ESM 2) showing the maximum solubility gold. Boiling is simulated by combining the cooling model with the incremental loss of volatile gas species from 350 to $200{ }^{\circ} \mathrm{C}$ following the method of Drummond and Ohmoto (1985). Gases are removed and the liquid re-equilibrated in a stepwise manner until $100 \%$ of the fluid has boiled at $200{ }^{\circ} \mathrm{C}$. a The partitioning of the volatile species, as well the $\mathrm{pH}$ (right axis). b The maximum solubility of gold (bold black line) during the boiling process as well as the predominant aqueous Au species

the oxidation of the fluid. As a result, the total solubility of gold increases, relative to the simple conductive cooling model, at temperatures from 341 to $304{ }^{\circ} \mathrm{C}$ (Fig. 16b) and then rapidly decreases with further cooling and phase separation. The competing effects of $\mathrm{H}_{2}$ and $\mathrm{H}_{2} \mathrm{~S}$ loss maintain a high solubility of gold until $\sim 304{ }^{\circ} \mathrm{C}$, where the volatility of $\mathrm{H}_{2}>$ $\mathrm{H}_{2} \mathrm{~S}$, resulting in oxidation of the liquid. The loss of $\mathrm{H}_{2} \mathrm{~S}$ eventually results in a decrease in the solubility of Au compared to the conductive cooling case (cross-over in Fig. 16b), but the remaining $\mathrm{H}_{2} \mathrm{~S}$ is sufficient to prevent gold deposition until relatively large degrees of boiling, similar to the situation observed by Reed and Spycher $(1984,1985)$. Precipitation of gold under these conditions, therefore, requires starting $\mathrm{Au}$ concentrations of at least several parts per billion, such as a starting concentration of $2 \mathrm{ppb}$ Au results in gold precipitation at $283{ }^{\circ} \mathrm{C}$, as observed in New Zealand geothermal wells and elsewhere (Brown 1986; Spycher and Reed 1989; Simmons et al. 2016). In some chimneys (Berkenbosch et al. 2012) and in mineral scales from boiling hydrothermal wells (Hardardóttir et al. 2010), distinctive banding of chalcopyrite, sphalerite, galena, and gold may be evidence of pulsed phase separation. These examples may reflect conditions where the liquid spontaneously flashes into steam, with dramatic effects on gold deposition (Brown 1986). This has been observed in (dashed lines). For comparison, the maximum solubility of Au from the corresponding conductive cooling model (see Fig. 9) is also plotted. The competing effects of $\mathrm{H}_{2}$ and $\mathrm{H}_{2} \mathrm{~S}$ maintain a high solubility of gold until $\sim 300{ }^{\circ} \mathrm{C}$, where the volatility of $\mathrm{H}_{2}>\mathrm{H}_{2} \mathrm{~S}$ and the fluids remain oxidized. The loss of $\mathrm{H}_{2} \mathrm{~S}$ eventually results in a decrease in the solubility of gold compared to the conductive cooling case (i.e., cross-over). Precipitation of gold under these conditions requires starting Au concentrations of at least several parts per billion, as observed in New Zealand geothermal wells and elsewhere (see Table 4)

active vents at water depths close to the boiling point of seawater, where the phase separation is highly localized (Schmidt et al. 2017; Gartman et al. 2018), and has resulted in spectacular $\mathrm{Cu}$ and $\mathrm{Au}$ grades in the deepest and hottest vents. But just a few meters away, the hydrothermal venting may be occurring at much lower temperatures, owing to mixing and cooling, resulting in highly variable grades developed over very short distances. Spycher and Reed (1989) modeled similar effects (superenthalpic boiling) by adding excess heat from either a dike intruding within the hydrothermal system or by self-sealing and then fracturing to release volatiles.

\section{Direct magmatic contribution}

The concentrations of metals in mid-ocean ridge black smoker fluids are considered by many to be too low to have produced the large-tonnage VMS deposits in the geologic record (Scott 1997). Mass-balance considerations for typical EPR vent fluids require large volumes of hydrothermal fluid and leached rock to produce a major ore deposit, suggesting that other sources of metals must be involved. Several researchers have concluded that direct magmatic contributions of metals are necessary (Urabe 1987; Huston and Large 1989; Stanton 
1990; Stanton 1994; Large et al. 1996; Scott 1997; Yang and Scott 2002; Yang and Scott 2006). However, the extent of this contribution is debated (Huston et al. 2011). At mid-ocean ridges, it is unlikely that exsolved magmatic brines are volumetrically significant, owing to the low $\mathrm{H}_{2} \mathrm{O}$ content of MORB, but such fluids may be produced by more waterrich magmas in arc environments, as $75 \%$ of recently active submarine arc volcanoes are either degassing or host magmatic-hydrothermal systems (de Ronde et al. 2011, 2014). Gruen et al. $(2012,2014)$ recently modeled the magmatic-hydrothermal system at the submarine Brothers volcano and concluded that a magmatic component played an integral part in the hydrothermal system, supporting earlier geochemical evidence (de Ronde et al. 2011).

The role of magmatic volatiles in the enrichment of $\mathrm{Au}$ seems certain, but the mechanism of transfer of the metal from the magma to the discharging hydrothermal fluids is unclear. The discovery of metal-rich, $\mathrm{CO}_{2}$-bearing fluids coexisting with melt inclusions in andesite from the eastern Manus Basin supports the suggestion that metals could be sourced directly from the magma or leached from magmatic rocks (Yang and Scott 1996, 2002; Kamenetsky et al. 2001). Limited oxygen and hydrogen isotope data also suggest that direct contributions of magmatic water have occurred in some arc and back-arc hydrothermal systems (Gamo et al. 1997; Marumo and Hattori 1999). Notable enrichments of certain trace elements (e.g., Bi, Se, In, Te, and $\mathrm{Sn}$ ) have been argued as evidence for a magmatic contribution to some deposits (Dekov and Savelli 2004; Hannington et al. 2005; Berkenbosch et al. 2012). The basis for suggesting that these elements may be magmatically derived is their common association in porphyry $\mathrm{Cu}$ deposits as well as experimental evidence for their strong partitioning into aqueous fluids during crystallization of felsic magmas (Candela and Piccoli 2005). Even at mid-ocean ridges, brine inclusions of probable magmatic derivation in subseafloor plutonic rocks contain daughter minerals of pyrite and chalcopyrite that indicate metal concentrations of up to 1000s of ppm Fe and $\mathrm{Cu}$ in the trapped fluids (Kelley and Delaney 1987; de Ronde 1995).

Only a small contribution from such brines, mixed with modified seawater, can account for major metal concentrations in the vent fluids (Yang and Scott 2006). Seawaterdominated hydrothermal fluids charged with $\mathrm{Au}$ from a deep magmatic source are strong candidates for $\mathrm{Cu}-\mathrm{Au}$ mineralization in some systems. However, the interpretation of a direct magmatic contribution to seafloor hydrothermal fluids is made difficult by the lack of data on the compositions of the magmatic fluids. Au concentrations in suspected magmatic fluids from seafloor hydrothermal vents have never been measured. However, up to $16 \mathrm{ppb} \mathrm{Au}$ has been measured in deep geothermal fluids from the magmatic-hydrothermal system at Lihir (Simmons and Brown 2006), representing a likely endmember concentration. Others have shown that the magmatic vapor plume of arc volcanoes, such as White Island, could deliver a significant amount of $\mathrm{Cu}$ and $\mathrm{Au}$ to the seafloor in a submarine setting, with combined fluxes of $110,000 \mathrm{~kg} / \mathrm{year}$ $\mathrm{Cu}, 2190 \mathrm{~kg} /$ year $\mathrm{Bi}$, and $>36 \mathrm{~kg} /$ year $\mathrm{Au}$ from passive degassing and quiescent eruptions (LeCloarec et al. 1992; Hedenquist et al. 1993).

\section{Discussion}

The many different styles of Au-rich SMS deposits (Table 3) highlight a wide range of processes that work independently or in combination to cause Au enrichment. Some of the conditions whereby different Au-bearing mineral assemblages may be precipitated are shown by reaction-path modeling, but the calculations also raise a number of questions. Simple conductive cooling of vent fluids buffered by different rock types (Figs. 9, 11, 12, and 13) can result in dramatically different $\mathrm{Zn}-\mathrm{Au}$ and $\mathrm{Cu}-\mathrm{Au}$ assemblages, depending on the starting concentrations of $\mathrm{Au}$. The conditions that promote or limit the precipitation of gold, and silver, include a complex interplay of temperature, $\mathrm{pH}$, and redox state. The concentrations of available ligands, such as $\mathrm{H}_{2} \mathrm{~S}_{\text {and }} \mathrm{Cl}^{-}$, in almost all types of seafloor hydrothermal fluids exceed the amounts required to form stable chloride and bisulfide complexes of $\mathrm{Au}$ and $\mathrm{Ag}$. As a result, fluids with metal concentrations typical of end-member MOR fluids must cool to lower temperatures in order to achieve gold and silver saturation. Mixing with cold seawater causes a decrease in $\mathrm{H}_{2} \mathrm{~S}$ but also $\mathrm{H}_{2}$, the result being an increase the solubility of gold, so that saturation is further delayed. Hydrothermal fluids that are more reduced, such as those buffered by ultramafic rocks, are able to transport less $\mathrm{Au}$ and $\mathrm{Ag}$, but may produce $\mathrm{Cu}-\mathrm{Au}$ assemblages because they become saturated at higher temperatures. More oxidized fluids, common in arc settings, are able to transport higher concentrations of $\mathrm{Au}$ and $\mathrm{Ag}$, leading to precipitation of $\mathrm{Au}$ in lower-temperature polymetallic assemblages. Where such fluids have higher end-member Au concentrations, due to magmatic contributions, they too become saturated at higher temperatures leading to a strong $\mathrm{Cu}-\mathrm{Au}$ association. Geochemical modeling also shows that the extent of the buffering during fluid ascent and cooling leads to even more complex mineral paragenesis and is a topic for further investigation.

The significant undersaturation of the MOR fluids begs the question: how is gold deposited in higher-temperature polymetallic and $\mathrm{Cu}$-rich assemblages in some deposits? Gold concentrations much higher than the modeled concentration of $\mathrm{Au}(0.1 \mathrm{ppb})$ are needed to saturate the liquid, as in the ARC fluids, and/or dramatic changes in fluid chemistry must occur, such as boiling. In the undersaturated fluids, the availability of $\mathrm{Au}$ in the rock is potentially a major control on enrichment. The remarkably consistent proportions of major 
and trace metals in the deposits closely match the metal ratios in their source rocks (Hannington 2014; Monecke et al. 2016). Average concentrations of Au in typical basaltic, ultramafic and continental/crustal source rocks (Table 6) are in the same order as the median grades in massive sulfides samples (MOR < UM < ARC: Fig. 2). However, the range of $\mathrm{Au}$ concentrations in the source rocks is small compared to the range of concentrations in the deposits and the hydrothermal fluids. Gold concentrations in basalt vary by no more than a factor of 5 (Table 6), whereas end-member fluid concentrations in MOR settings span more than 2 orders of magnitude $(<0.1 \mathrm{ppb}$ to at least $10 \mathrm{ppb}$ : Table 5). Thus, the enrichment of Au cannot be due to variations in source rock concentration alone, and another process is needed to account for high concentrations observed in some fluids. Moreover, an increase in the solubility of the gold will make no difference to the end-member concentration if all of the Au has already been leached from the rock.

Continuous recycling of metals during the lifetime of a vent system may upgrade the metal concentrations in the fluids, providing a local source for very high Au concentrations in the fluids and resulting in some exceptionally rich zones (e.g., Hannington et al. 1995). In some cases, the metal may be stripped from a deposit, as in a process of "over-refining" (Hannington et al. 1998). In volcanic arc settings, it is highly probable that direct magmatic contributions to the hydrothermal fluids are responsible for $\mathrm{Au}$ enrichment, and high $\mathrm{Au}$ concentrations of the fluids, explaining the $\mathrm{Cu}-\mathrm{Au}$ enrichment in some deposits. However, other deposits are enriched in $\mathrm{Au}$ that do not show any evidence of a magmatic input in terms of trace elements, alteration, or isotopic systems. Recent data from deep drill holes at Reykjanes suggest that geothermal fluids may be progressively enriched in Au over time by boiling in the reservoir zone (Hannington et al. 2016). Some of these geothermal fluids have bulk Au concentrations far in excess of liquid saturation indicating that at least part of the transported gold must be present as nanoparticle suspensions.

\section{Conclusions}

We have examined a number of the factors that control gold deposition in black smoker deposits using simultaneous aqueous-mineral-gas equilibria. Reaction-path modeling of simple conductive cooling and mixing of end-member hydrothermal fluids shows that much of the variability in $\mathrm{Au}$ and $\mathrm{Ag}$ deposition, such as early $\mathrm{Cu}-\mathrm{Au}$ in ultramafic systems and later $\mathrm{Zn}-\mathrm{Au}$ under normal midocean ridge conditions, is a consequence of the rock buffer. In MOR systems, gold deposition is delayed to lower temperatures owing to the stability of the $\mathrm{AuHS}^{\circ}$ and $\mathrm{Au}(\mathrm{HS})_{2}{ }^{-}$complexes at moderate $\mathrm{pH}$ and $f \mathrm{O}_{2}$ (PPM and PEQMAP buffers). During conductive cooling, gold precipitation after the start of sphalerite deposition is very rapid, with $>90 \%$ of the gold deposited in the first $25^{\circ} \mathrm{C}$ of cooling below $150{ }^{\circ} \mathrm{C}$. The result is a low-temperature $\mathrm{Zn}-\mathrm{Au}$ polymetallic assemblage, with gold and silver deposited together with galena and sulfosalts. In ultramaficdominated systems, gold deposition occurs earlier owing to the lower stability of the AuHS ${ }^{\circ}$ complex at low $f \mathrm{O}_{2}$ (FMQ buffer). Gold deposition begins at $250{ }^{\circ} \mathrm{C}$, before sphalerite deposition and is slower, requiring $75{ }^{\circ} \mathrm{C}$ of cooling to deposit $>90 \%$ of the gold. The result is a higher-temperature $\mathrm{Cu}-\mathrm{Au}$ assemblage, with gold deposited before silver in an early bornite-chalcopyrite assemblage. In sediment-dominated systems, the much higher $\mathrm{pH}$ stabilizes $\mathrm{Au}(\mathrm{HS})_{2}{ }^{-}$and keeps gold in solution to very low temperature $\left(\sim 70{ }^{\circ} \mathrm{C}\right)$, after the precipitation of most sulfides, resulting in a relatively Au-poor polymetallic sulfide assemblage and very late-stage deposition of gold, for example, with amorphous silica. In ARC systems, with higher initial Au concentrations in the fluids, gold deposition occurs at a slightly higher temperatures than in MOR systems, together with chalcopyrite, sphalerite, tennantite, and galena, resulting in an Au-rich polymetallic sulfide assemblage.

In all cases, the modeled end-member fluids are highly undersaturated, and a complex interplay of physicochemical processes affecting temperature, $\mathrm{pH}$, and redox state controls the timing of gold precipitation, the style of mineralization, and the metal grades. Conductive cooling, down to ambient temperatures, is an efficient mechanism for the precipitation of native gold and silver at low temperatures in all but the ultramafic rock-hosted systems. Mixing with cold seawater can shift the deposition of gold to even lower temperatures mainly because of the increased stability of $\mathrm{AuOH}^{\circ}$. During boiling, the loss of $\mathrm{H}_{2}\left(>\mathrm{H}_{2} \mathrm{~S}\right)$ causes an initial increase in the solubility of gold, followed by a rapid decrease in solubility due to removal of $\mathrm{H}_{2} \mathrm{~S}$ and deposition of gold at higher temperatures than for conductive cooling alone. Silver precipitation during boiling is limited due to the conservative behavior of $\mathrm{Cl}^{-}$, providing an explanation for the occurrence of gold of high fineness in $\mathrm{Cu}-\mathrm{Au}$ assemblages associated with hightemperature boiling. However, modeled grades of $\mathrm{Au}$ and $\mathrm{Ag}$ are generally lower than those in the sampled deposits, suggesting that a number of additional processes must contribute to the total precious metal budget. New data from the seafloor are highlighting some of the processes that are responsible for the most Au-rich deposits. Recognizing that such complexity exists, and that Au enrichment may be attributable to different processes in different deposits, or even in different parts of the same deposit, has important implications for exploration.

Acknowledgments Helpful reviews that improved the paper were provided by J.L. Pilote, J. Jamieson, and the editor. 
Funding information The research presented in this study was supported by a Helmholtz Postdoctoral Fellowship to SF and a NSERC Discovery Grant awarded to M. Hannington.

Open Access This article is distributed under the terms of the Creative Commons Attribution 4.0 International License (http:// creativecommons.org/licenses/by/4.0/), which permits unrestricted use, distribution, and reproduction in any medium, provided you give appropriate credit to the original author(s) and the source, provide a link to the Creative Commons license, and indicate if changes were made.

\section{References}

Akinfiev NN, Zotov AV (2001) Thermodynamic description of chloride, hydrosulfide, and hydroxo complexes of $\mathrm{Ag}$ (I), $\mathrm{Cu}$ (I), and $\mathrm{Au}$ (I) at temperatures of $25-500^{\circ} \mathrm{C}$ and pressures of $1-2000$ bar. Geochem Int 39:990-1006

Akinfiev NN, Zotov AV (2010) Thermodynamic description of aqueous species in the system $\mathrm{Cu}-\mathrm{Ag}$-Au-S-O-H at temperatures of $0-600^{\circ} \mathrm{C}$ and pressures of 1-3000 bar. Geochem Int 48:714-720

Allen DE, Seyfried WE Jr (2003) Compositional controls on vent fluids from ultramafic-hosted hydrothermal systems at mid-ocean ridges: an experimental study at $400^{\circ} \mathrm{C}, 500$ bars. Geochim Cosmochim Acta 67:1531-1542

Anschutz P, Blanc G (1995) Chemical mass balances in metalliferous deposits from the Atlantis II Deep, Red Sea. Geochim Cosmochim Acta 59:4205-4218

Anschutz P, Blanc G, Stille P (1995) Origin of fluids and the evolution of the Atlantis II Deep hydrothermal system, Red Sea: strontium isotope study. Geochim Cosmochim Acta 59:4799-4808

Baker ET, German CR (2004) On the global distribution of hydrothermal vent fields. In: German CR, Lin J, Parson LM (eds) Mid-ocean ridges: hydrothermal interactions between the lithosphere and oceans. American Geophysical Union, Washington DC, pp 245266

Barton PB Jr (1978) Some ore textures involving sphalerite from the Furutobe Mine, Akita Prefecture, Japan. Min Geol 28:293-300

Barton PB, Toulmin P (1966) Phase relations involving sphalerite in the Fe-Zn-S system. Econ Geol 61:815-849

Beaulieu SE, Baker ET, German CR, Maffei A (2013) An authoritative global database for active submarine hydrothermal vent fields. Geochem Geophys Geosyst 14:4892-4905

Berkenbosch HA, de Ronde CEJ, Gemmell JB, McNeill AW, Goemann K (2012) Mineralogy and formation of black smoker chimneys from Brothers submarine volcano, Kermadec arc. Econ Geol 107:16131633

Bethke CM (2008) Geochemical and biogeochemical modeling. Cambridge University Press, Cambridge, p 564

Binns RA, Parr JM, Gemmell JB, Whitford DJ, Dean JA (1997) Precious metals in barite-silica chimneys from Franklin seamount, Woodlark Basin, Papua New Guinea. Mar Geol 142:119-141

Botcharnikov RE, Linnen RL, Wilke M, Holtz F, Jogo JJ (2010) High gold concentrations in sulphide-bearing magma under oxidizing conditions. Nat Geosci 4:112-115

Brown KL (1986) Gold deposition from geothermal discharges in New Zealand. Econ Geol 81:979-983

Butterfield DA, Massoth GJ, McDuff RE, Lupton JE, Lilley MD (1990) Geochemistry of hydrothermal fluids from axial seamount hydrothermal emissions study vent field, Juan de Fuca ridge: subseafloor boiling and subsequent fluid-rock interaction. J Geophys Res Solid Earth 95:12895-12921

Campbell AC, Edmond JM, Colodner D, Palmer MR (1987) Chemistry of hydrothermal fluids from the Mariana trough back arc basin in comparison to mid-ocean ridge fluids. EOS Trans Am Geophys Union 68:1531

Candela PA, Piccoli PM (2005) Magmatic processes in the development of porphyry-type systems. In: Hedenquist J, Thompson G, Goldfarb RJ, Richards JP (eds) One hundredth anniversary volume. Society of Economic Geologists, Littleton, pp 25-38

Charlou JL, Donval JP, Fouquet Y, Jean-Baptiste P, Holm N (2002) Geochemistry of high $\mathrm{H} 2$ and $\mathrm{CH} 4$ vent fluids issuing from ultramafic rocks at the Rainbow hydrothermal field $\left(36^{\circ} 14^{\prime} \mathrm{N}, \mathrm{MAR}\right)$. Chem Geol 191:345-359

Craddock PR (2009) Geochemical tracers of processes affecting the formation of seafloor hydrothermal fluids and deposits in the Manus back-arc basin. Dissertation, Massachusetts Institute of Technology and Woods Hole Oceanographic Institution, Woods Hole

de Ronde CEJ (1995) Fluid chemistry and isotopic characteristics of seafloor hydrothermal systems and associated VMS deposits: potential for magmatic contributions. Min Assoc of Canada Short Course Series 23:479-509

de Ronde CEJ, Massoth GJ, Butterfield DA, Christenson BW, Ishibashi J, Ditchburn RG, Hannington MD, Brathwaite RL, Lupton JE, Kamenetsky VS, Graham IJ, Zellmer GF, Dziak RP, Embley RW, Dekov VM, Munnik F, Lahr J, Evans LJ, Takai K (2011) Submarine hydrothermal activity and gold-rich mineralization at Brothers volcano, Kermadec arc, New Zealand. Mineral Deposita 46:541-584

de Ronde CEJ, Berkenbosch HA, Hannington MD (2014) Gold-rich hydrothermal systems related to submarine volcanic arcs. In: Gold14@Kalgoorlie.08.10-10.10.2014, Curtin Univ., Kalgoorlie, Austrialia. Extented abstract. pp 19-21

Dekov VM, Savelli C (2004) Hydrothermal activity in the SE Tyrrhenian Sea: an overview of 30 years of research. Mar Geol 204:161-185

DeMets C, Gordon RG, Argus DF (2010) Geologically current plate motions. Geophys J Int 181:1-80

Driesner T, Heinrich CA (2007) The system H2O-NaCl. Part I: correlation formulae for phase relations in temperature-pressure-composition space from 0 to $1000^{\circ} \mathrm{C}, 0$ to $5000 \mathrm{bar}$, and 0 to $1 \mathrm{XNaCl}$. Geochim Cosmochim Acta 71:4880-4901

Drummond SE, Ohmoto H (1985) Chemical evolution and mineral deposition in boiling hydrothermal systems. Econ Geol 80:126-147

Dubé B, Gosselin P, Mercier-Langevin P, Hannington M D, Galley A G (2007) Gold-rich volcanogenic massive sulphide deposits. Geol Assoc of Canada, MDD Spec Pub 5:75-94

Eldridge CS, Barton PB Jr, Ohmoto H (1983) Mineral textures and their bearing on formation of the Kuroko orebodies. Econ Geol Monogr 5:241-281

Falkner KK, Edmond JM (1990) Gold in seawater. Earth Planet Sc Lett 98:208-221

Firstova A, Stepanova T, Cherkashov G, Goncharov A, Babaeva S (2016) Composition and formation of gabbro-peridotite hosted seafloor massive sulfide deposits from the Ashadze-1 hydrothermal field, Mid-Atlantic Ridge. Minerals 6:19

Fouquet Y, Wafik A, Cambon P, Mével C, Meyer G, Gente P (1993) Tectonic setting and mineralogical and geochemical zonation in the Snake Pit sulfide deposit (Mid-Atlantic Ridge at $23^{\circ} \mathrm{N}$ ). Econ Geol 88:2018-2036

Fouquet Y, Cambon P, Etoubleau J, Charlou J L, Ondréas H, Barriga S, Cherkashov G., Semkova T, Poroshina I, Bohn M, Donval JP, Katell H, Murphy P, Rouxel O (2013) Geodiversity of hydrothermal processes along the Mid-Atlantic Ridge and ultramafic-hosted mineralization: a new type of oceanic $\mathrm{Cu}-\mathrm{Zn}$-Co-Au volcanogenic massive sulfide deposit. In: Rona PA, Devey CW, Dyment J, Murton BJ (eds) Diversity of hydrothermal systems on slow spreading ocean ridges. Geoph Monog Series 188:321-367

Francheteau J, Needham HD, Choukroune P, Juteau T, Séguret M, Ballard RD, Fox PJ, Normark W, Carranza A, Cordoba D, Guerrero J, Rangin C, Bougault H, Cambon P, Hekinian R (1979) 
Massive deep-sea sulphide ore deposits discovered on the East Pacific Rise. Nature 277:523-528

Franklin JM, Gibson HL, Jonasson IR, Galley AG (2005) Volcanogenic massive sulfide deposits. In: Hedenquist J, Thompson G, Goldfarb RJ, Richards JP (eds) One hundredth anniversary volume. Society of Economic Geologists, Littleton, pp 523-561

Früh-Green GL, Connolly JAD, Plas A, Kelley DS, Grobéty B (2004) Serpentinization of oceanic peridotites: implications for geochemical cycles and biological activity. In: Wilcock WSD, Kelley DS, Baross JA et al (eds) The subseafloor biosphere at mid-ocean ridges. American Geophysical Union, Washington, D. C, pp 119-136

Gamo T, Okamura K, Charlou JL, Urabe T, Auzende JM, Ishibashi J, Shitashima K, Chiba H (1997) Acidic and sulfate-rich hydrothermal fluids from the Manus back-arc basin, Papua New Guinea. Geology 25:139-142

Gartman A, Hannington MD, Jamieson JW, Peterkin B, GarbeSchönberg D, Findlay AJ, Fuchs S, Kwasnitschka T (2018) Boiling-induced formation of colloidal gold in black smoker hydrothermal fluids. Geology 46:39-42

German CR, Von Damm KL (2004) 6.07-hydrothermal processes. In: Holland HD, Turekian KK (eds) Treatise on geochemistry. Elsevier/ Pergamon, Amsterdam, pp 181-222

German CR, Petersen S, Hannington MD (2016) Hydrothermal exploration of mid-ocean ridges: where might the largest sulfide deposits be forming? Chem Geol 420:114-126

Gruen G, Weis P, Driesner T, de Ronde CEJ, Heinrich CA (2012) Fluidflow patterns at Brothers volcano, southern Kermadec arc: insights from geologically constrained numerical simulations. Econ Geol 107:1595-1611

Gruen G, Weis P, Driesner T, de Ronde CEJ, Heinrich CA (2014) Hydrodynamic modeling of magmatic-hydrothermal activity at submarine arc volcanoes, with implications for ore formation. Earth Planet Sc Lett 404:307-318

Halbach P, Pracejus B, Maerten A (1993) Geology and mineralogy of massive sulfide ores from the central Okinawa Trough, Japan. Econ Geol 88:2210-2225

Hall G, Vaive J, Hannington MD, McConachy TF (1988) Gold and associated trace elements in vent waters and suspended particulates from Southern Explorer Ridge. EOS Trans Am Geophys Union 69: 1501

Hamlyn PR, Keays RR, Cameron WE, Crawford AJ, Waldron H (1985) Precious metals in magnesian low-Ti lavas: implications for metallogenesis and sulfur saturation in primary magmas. Geochim Cosmochim Acta 49:1797-1811

Hannington MD (2014) 13.18 — volcanogenic massive sulfide deposits. In: Holland HD, Turekian KK (eds) Treatise on geochemistry (Second edition). Elsevier, Oxford, pp 463-488

Hannington MD, Scott SD (1988) Gold and silver potential of polymetallic sulfide deposits on the sea floor. Mar Min 7:271-285

Hannington MD, Scott SD (1989a) Gold mineralization in volcanogenic massive sulfides: implications of data from active hydrothermal vents on the modern seafloor. Econ Geol Monogr 6:491-507

Hannington MD, Scott SD (1989b) Sulfidation equilibria as guides to gold mineralization in volcanogenic massive sulfides; evidence from sulfide mineralogy and the composition of sphalerite. Econ Geol 84:1978-1995

Hannington MD, Peter JM, Scott SD (1986) Gold in sea-floor polymetallic sulfide deposits. Econ Geol 81:1867-1883

Hannington MD, Thompson G, Rona PA, Scott SD (1988) Gold and native copper in supergene sulphides from the Mid-Atlantic Ridge. Nature 333:64-66

Hannington MD, Herzig PM, Scott SD (1991a) Auriferous hydrothermal precipitates on the modern seafloor. In: Foster RP (ed) Gold metallogeny and exploration. Springer, Dordrecht, pp 249-282
Hannington MD, Herzig PM, Scott S, Thompson G, Rona P (1991b) Comparative mineralogy and geochemistry of gold-bearing sulfide deposits on the mid-ocean ridges. Mar Geol 101:217-248

Hannington MD, Tivey MK, Laroque ACL, Petersen S, Rona PA (1995) The occurence of gold in sulfide deposits of the TAG hydrothermal field, Mid-Atlantic Ridge. Can Mineral 33:1285-1310

Hannington MD, Galley AG, Herzig PM, Petersen S (1998) Comparison of the TAG mound and stockwork complex with Cyprus-type massive sulfide deposits. Proceedings of the Ocean Drilling Program, Scientific results 158:389-415

Hannington MD, Poulsen KH, Thompson JFH (1999) Volcanogenic gold in the massive sulfide environment

Hannington MD, Petersen S, Herzig PM, Jonasson IR (2004) A global database of seafloor hydrothermal systems, including a digital database of geochemical analyses of seafloor polymetallic sulfides. Geological Survey of Canada, Open File 4598, 1 CD-ROM

Hannington MD, de Ronde CDJ, Petersen S (2005) Sea-floor tectonics and submarine hydrothermal systems. In: Hedenquist J, Thompson G, Goldfarb RJ, Richards JP (eds) One hundredth anniversary volume. Society of Economic Geologists, Littleton, pp 111-141

Hannington MD, Jamieson J, Monecke T, Petersen S (2010) Modern seafloor massive sulfides and base metal resources: toward an estimate of global sea-floor massive sulfide potential. Rev Econ Geol 15: 317-337

Hannington MD, Hardardóttir V, Garbe-Schönberg D, Brown KL (2016) Gold enrichment in active geothermal systems by accumulating colloidal suspensions. Nat Geosci 9:1-5

Hannington MD, Petersen S, Monecke T, Mercier-Langevin P (2017) Divining gold in VMS systems: news from the seafloor. Proc. 14th SGA biennal meeting: 43-46

Hardardóttir V, Brown KL, Fridriksson T, Hedenquist JW, Hannington MD, Thorhallsson S (2009) Metals in deep liquid of the Reykjanes geothermal system, southwest Iceland: implications for the composition of seafloor black smoker fluids. Geology 37:1103-1106

Hardardóttir V, Hannington M, Hedenquist J, Kjarsgaard I, Hoal K (2010) $\mathrm{Cu}$-rich scales in the Reykjanes geothermal system, Iceland. Econ Geol 105:1143-1155

Hedenquist JW, Simmons SF, Giggenbach WF, Eldridge CS (1993) White Island, New Zealand, volcanic-hydrothermal system represents the geochemical environment of high-sulfidation $\mathrm{Cu}$ and $\mathrm{Au}$ ore deposition. Geology 21:731-734

Hekinian R, Renard V, Cheminée JL (1983) Hydrothermal deposits on the East Pacific Rise near $13^{\circ} \mathrm{N}$ : geological setting and distribution of active sulfide chimneys. In: Rona PA, Boström K, Laubier L, Smith KL (eds) Hydrothermal processes at seafloor spreading centers. Springer, Boston, pp 571-594

Helgeson HC (1969) Thermodynamics of hydrothermal systems at elevated temperatures and pressures. Am J Sci 267:729-804

Herzig PM, Hannington MD (1990) Gold found in Lau back-arc sulfides. EOS Trans AGU 71:1090

Herzig PM, Hannington MD (1995) Polymetallic massive sulfides at the modem seafloor: a review. Ore Geol Rev 10:95-115

Herzig PM, Hannington M, Fouquet Y, von Stackelberg U, Petersen S (1993) Gold-rich polymetallic sulfides from the Lau back arc and implications for the geochemistry of gold in sea-floor hydrothermal systems of the Southwest Pacific. Econ Geol 88:2182-2209

Huston DL (2000) Gold in volcanic-hosted massive sulfide deposits: distribution, genesis, and exploration. In: Hagemann SG, Brown PE (eds) Gold in 2000. Society of Economic Geologists, Littleton, pp 401-426

Huston DL, Large RR (1989) A chemical model for the concentration of gold in volcanogenic massive sulphide deposits. Ore Geol Rev 4: 171-200

Huston DL, Relvas JMRS, Gemmell JB, Drieberg S (2011) The role of granites in volcanic-hosted massive sulphide ore-forming systems: 
an assessment of magmatic-hydrothermal contributions. Mineral Deposita 46:473-507

Ihle T, Petersen S, Herzig PM, Hannington MD (2005) Siting of gold and characteristics of gold-bearing massive sulfides from the interior of the felsic-hosted PACMANUS massive sulfide deposit, eastern Manus basin (PNG). In: Mao J, Bierlein FP (eds) Mineral deposit research: meeting the global challenge. Springer, Berlin, pp 623 626

Iizasa K, Asada A, Mizuno K, Katase F, Lee S, Kojima M, Ogawa N (2018) Native gold and gold-rich sulfide deposits in a submarine basaltic caldera, Higashi-Aogashima hydrothermal field, IzuOgasawara frontal arc, Japan. Mineral Deposita 107:1613-1616

Janecky DR, Shanks WC (1988) Computational modeling of chemical and sulfur isotopic reaction processes in sea-floor hydrothermal systems; chimneys, massive sulfide, and subjacent alteration zones. Can Mineral 26:805-825

Jenner FE, O'Neill HSC (2012a) Analysis of 60 elements in 616 ocean floor basaltic glasses. Geochem Geophys Geosyst 13(1):1-11

Jenner FE, O’Neill HSC (2012b) Major and trace analysis of basaltic glasses by laser-ablation ICP-MS. Geochem Geophys Geosyst 13(3):11-17

Jenner FE, Arculus RJ, Mavrogenes JA, Dyriw NJ, Nebel O, Hauri EH (2012) Chalcophile element systematics in volcanic glasses from the northwestern Lau Basin. Geochem Geophys Geosyst 13(6):1-25

JOGMEC - Japan Oil, Gas and Metals National Corporation (2016) 2016 annual report, pp 52

Johnson JW, Oelkers EH, Helgeson HC (1992) SUPCRT92: a software package for calculating the standard molal thermodynamic properties of minerals, gases, aqueous species, and reactions from 1 to 5000 bar and 0 to $1000^{\circ} \mathrm{C}$. Comput Geosci 18:899-947

Kamenetsky VS, Binns RA, Gemmell JB, Crawford AJ, Mernagh TP, Maas R, Steele D (2001) Parental basaltic melts and fluids in eastern Manus backarc basin: implications for hydrothermal mineralisation. Earth Planet Sc Lett 184:685-702

Keays RR (1987) Principles of mobilization (dissolution) of metals in mafic and ultramafic rocks - the role of immiscible magmatic sulphides in the generation of hydrothermal gold and volcanogenic massive sulphide deposits. Ore Geol Rev 2:47-63

Keays RR, Scott RB (1976) Precious metals in ocean-ridge basalts; implications for basalts as source rocks for gold mineralization. Econ Geol 71:705-720

Keith M, Häckel F, Haase KM, Schwarz-Schampera U, Klemd R (2016) Trace element systematics of pyrite from submarine hydrothermal vents. Ore Geol Rev 72:728-745

Kelley DS, Delaney JR (1987) Two-phase separation and fracturing in mid-ocean ridge gabbros at temperatures greater than $700^{\circ} \mathrm{C}$. Earth Planet Sc Lett 83:53-66

Kelley DS, Früh-Green GL (1999) Abiogenic methane in deep-seated mid-ocean ridge environments: insights from stable isotope analyses. J Geophys Res Solid Earth 104:10439-10460

Kong X-Z, Tutolo BM, Saar MO (2013) DBCreate: a SUPCRT92-based program for producing EQ3/6, TOUGHREACT, and GWB thermodynamic databases at user-defined T and P. Comput Geosci 51:415417

Large RR (1992) Australian volcanic-hosted massive sulfide deposits; features, styles, and genetic models. Econ Geol 87:471-510

Large RR, Huston DL, McGoldrick PJ, Ruxton PA, McArthur G (1989) Gold distribution and genesis in Australian volcanogenic massive sulfide deposits and their significance for gold transport models. Econ Geol Monogr 6:520-535

Large R, Doyle M, Raymond O, Cooke D, Jones A, Heasman L (1996) Evaluation of the role of Cambrian granites in the genesis of world class VHMS deposits in Tasmania. Ore Geol Rev 10:215-230

Laurila TE, Hannington MD, Petersen S, Garbe-Schönberg D (2014) Trace metal distribution in the Atlantis II Deep (Red Sea) sediments. Chem Geol 386:80-100
Laurila TE, Hannington MD, Leybourne M, Petersen S, Devey CW, Garbe-Schönberg D (2015) New insights into the mineralogy of the Atlantis II Deep metalliferous sediments, Red Sea. Geochem Geophys Geosyst 16:4449-4478

LeCloarec MF, Allard P, Ardouin B, Giggenbach WF, Sheppard DS (1992) Radioactive isotopes and trace elements in gaseous emissions from White Island, New Zealand. Earth Planet Sc Lett 108: 19-28

Lein AY, Cherkashev GA, Ul'yanov AA, Stepanova TV, Sagalevich AM, Bogdanov YA, Gurvich EG, Torokhov MP (2003) Mineralogy and geochemistry of sulfide ores from the logachev-2 and rainbow fields: resemblance and distinction features. Geochem Int 41:271294

Lonsdale P (1977) Clustering of suspension-feeding macrobenthos near abyssal hydrothermal vents at oceanic spreading centers. Deep-Sea Res 24:857-863

Marumo K, Hattori KH (1999) Seafloor hydrothermal clay alteration at Jade in the back-arc Okinawa Trough: mineralogy, geochemistry and isotope characteristics. Geochim Cosmochim Acta 63:27852804

Massoth GJ, Butterfield DA, Lupton JE, McDuff RE, Lilley MD, Jonasson IR (1989) Submarine venting of phase-separated hydrothermal fluids at axial volcano, Juan de Fuca ridge. Nature 340:702705

McKibben M, Hardie L (1997) Ore-forming brines in active continental rifts. In: Barnes HL (ed) Geochemistry of hydrothermal ore deposits, 3rd edn. Wiley, New York, pp 877-930

Melekestseva IY, Kotlyarov VA, Khvorov PV, Ivanov VN, Beltenev VE, Dobretsova IG (2010) Noble-metal mineralization in the Semenov-2 hydrothermal field $\left(13^{\circ} 31^{\prime} \mathrm{N}\right)$, Mid-Atlantic Ridge. Geol Ore Deposit+ 52:800-810

Melekestseva IY, Tret'yakov GA, Nimis P, Yuminov AM, Maslennikov VV, Maslennikova SP, Kotlyarov VA, Beltenev VE, Danyushevsky LV, Large R (2014) Barite-rich massive sulfides from the Semenov1 hydrothermal field (Mid-Atlantic Ridge, $13^{\circ} 30.87^{\prime} \mathrm{N}$ ): evidence for phase separation and magmatic input. Mar Geol 349:37-54

Melekestseva IY, Maslennikov VV, Tret'yakov GA, Nimis P, Beltenev VE, Rozhdestvenskaya II, Maslennikova SP, Belogub EV, Danyushevsky L, Large R, Yuminov AM, Sadykov SA (2017) Gold- and silver-rich massive sulfides from the Semenov-2 hydrothermal field, $13^{\circ} 31.13^{\prime} \mathrm{N}$, Mid-Atlantic Ridge: a case of magmatic contribution? Econ Geol 112:741-773

Mercier-Langevin P, Hannington MD, Dubé B, Bécu V (2011) The gold content of volcanogenic massive sulfide deposits. Mineral Deposita 46:509-539

Monecke T, Petersen S, Hannington MD (2014) Constraints on water depth of massive sulfide formation: evidence from modern seafloor hydrothermal systems in arc-related settings. Econ Geol 109:20792101

Monecke T, Petersen S, Hannington MD, Grant H, Samson I (2016) The minor element endowment of modern sea-floor massive sulfide deposits and comparison with deposits hosted in ancient volcanic successions. Rev Econ Geol 18:245-306

Moss R, Scott SD (2001) Geochemistry and mineralogy of gold-rich hydrothermal precipitates from the eastern Manus Basin, Papua New Guinea. Can Mineral 39:957-978

Moss R, Scott SD, Binns RA (2001) Gold content of eastern Manus Basin volcanic rocks: implications for enrichment in associated hydrothermal precipitates. Econ Geol 96:91-107

Mozgova NN, Trubkin NV, Borodaev YS, Cherkashev GA, Stepanova TV, Semkova TA, Uspenskaya TY (2008) Mineralogy of massive sulfides from the Ashadze hydrothermal field, $13^{\circ} \mathrm{N}$, Mid-Atlantic Ridge. Can Mineral 46:545-567

Murphy PJ, Meyer G (1998) A gold-copper association in ultramafichosted hydrothermal sulfides from the Mid-Atlantic Ridge. Econ Geol 93:1076-1083 
Nautilus Minerals Inc. (2012) Mineral resource estimate for the Solwara 1 Project, Bismarck Sea, Papua New Guinea, NI43-101 technical report, pp 240

Park JW, Campbell IH, Kim J, Moon JW (2015) The role of late sulfide saturation in the formation of a $\mathrm{Cu}$ - and $\mathrm{Au}$-rich magma: insights from the platinum group element geochemistry of NiuatahiMotutahi lavas, Tonga rear arc. J Petrol 56:59-81

Patten CGC, Pitcairn IK, Teagle DAH (2017) Hydrothermal mobilisation of $\mathrm{Au}$ and other metals in supra-subduction oceanic crust: insights from the Troodos ophiolite. Ore Geol Rev 86:487-508

Pearce JE, Ernewein M, Bloomer SH, Parson LM, Murton BJ, Johnson LE (1995) Geochemistry of Lau Basin volcanic rocks: influence of ridge segmentation and arc proximity. Geol Soc Lond Spec Publ 81: $53-75$

Perfit MR, Ridley W, Jonasson IR (1999) Geologic, petrologic, and geochemical relationships between magmatism and massive sulfide mineralization along the eastern Galapagos spreading center. Rev Econ Geol 8:75-100

Petersen S, Herzig PM, Hannington MD, Hannington MD, Jonasson IR, Arribas A (2002) Submarine gold mineralization near Lihir Island, New Ireland fore-arc, Papua New Guinea. Econ Geol 97:1795-1813

Petersen S, Monecke T, Westhues A, Hannington MD, Gemmell JB, Sharpe R, Peters M, Strauss H, Lackschewitz K, Augustin N, Gibson H, Kleeberg R (2014) Drilling shallow-water massive sulfides at the Palinuro volcanic complex, Aeolian Island arc, Italy. Econ Geol 109:2129-2158

Petersen S, Krätschell A, Augustin N, Jamieson J, Hein JR, Hannington MD (2016) News from the seabed - geological characteristics and resource potential of deep-sea mineral resources. Mar Policy 70: $175-187$

Pitcairn IK (2013) Background concentrations of gold in different rock types. Appl Earth Sci 120:31-38

Pokrovski GS, Akinfiev NN, Borisova AY, Zotov AV, Kouzmanov K (2014) Gold speciation and transport in geological fluids: insights from experiments and physical-chemical modelling. Geol Soc Spec Publ 402:9-70

Portnyagin M, Golowin R, Garbe-Schönberg D (2015) Gold-rich Manihiki magmas: a high precision LA-ICP-MS study of glasses obtained during SO-193 and SO-225 expeditions. Statusseminar Meeresforschung mit FS SONNE, Bremen, pp 1-5

Poulsen KH, Hannington MD (1996) Volcanic-associated massive sulphide gold. In: Eckstrand OR, Sinclair WD, Thorpe, RI (eds) Geology of Canadian mineral deposit types. Geology of Canada Series 8:183-196

Prichard HM, Puchelt H, Eckhardt JD, Fisher PC (1996) Platinum-groupelement concentrations in mafic and ultramafic lithologies drilled from Hess deep. In: Mevel C, Gillis KM, Allan JF, Meyer PS (eds) Proceedings of the ocean drilling program, scientific results, Vol. 147, College Station Texas, pp 77-90

Reed MH (1982) Calculation of multicomponent chemical equilibria and reaction processes in systems involving minerals, gases and an aqueous phase. Geochim Cosmochim Acta 46:513-528

Reed MH (1998) Calculation of simultaneous chemical equilibria in aqueous-mineral-gas systems and its application to modeling hydrothermal process. Rev Econ Geol 10:109-124

Reed MH, Palandri J (2006) Sulfide mineral precipitation from hydrothermal fluids. In: Vaughan JR (ed) Sulfide mineralogy and geochemistry, reviews in mineralogy. Mineralogical Society of America, Chantilly, pp 609-631

Reed MH, Spycher N (1984) Calculation of $\mathrm{pH}$ and mineral equilibria in hydrothermal waters with application to geothermometry and studies of boiling and dilution. Geochim Cosmochim Acta 48:14791492

Reed MH, Spycher NF (1985) Boiling, cooling and oxidation in epithermal systems: a numerical approach. Rev Econ Geol 2:249 272
Rudnick RL, Gao S (2014) 4.1 - composition of the continental crust. In: Holland HD, Turekian KK (eds) Treatise on geochemistry, 2nd edn. Elsevier, Oxford, pp 1-51

Schmidt K, Garbe Schönberg D, Hannington MD, Anderson MO, Bühring B, Haase K, Haruel C, Lupton J, Koschinsky A (2017) Boiling vapour-type fluids from the Nifonea vent field (New Hebrides back-arc, Vanuatu, SW Pacific): geochemistry of an early-stage, post-eruptive hydrothermal system. Geochim Cosmochim Acta 207:185-209

Scott SD (1997) Submarine hydrothermal systems. In: Barnes HL (ed) Geochemistry of hydrothermal ore deposits, 3rd Edition. Wiley, New York, pp 797-875

Seyfried WE Jr, Ding K (1995) Phase equilibria in subseafloor hydrothermal systems: a review of the role of redox, temperature, $\mathrm{pH}$ and dissolved $\mathrm{Cl}$ on the chemistry of hot spring fluids at mid-ocean ridges. In: Seafloor hydrothermal systems: physical, chemical, biological, and geological interactions. American Geophysical Union, Washington, DC, pp 248-272

Seyfried WE Jr, Ding K, Berndt ME (1991) Phase equilibria constraints on the chemistry of hot spring fluids at mid-ocean ridges. Geochim Cosmochim Acta 55:3559-3580

Seyfried WE Jr, Ding K, Berndt ME, Chen X (1999) Experimental and theoretical controls on the composition of mid-ocean ridge hydrothermal fluids. Rev Econ Geol 8:181-200

Shock E, Canovas P (2010) The potential for abiotic organic synthesis and biosynthesis at seafloor hydrothermal systems. Geofluids 93: 1927-1192

Shock EL, Schulte MD (1998) Organic synthesis during fluid mixing in hydrothermal systems. J Geophys Res Solid Earth 103:2851328527

Shock EL, Sassani DC, Willis M, Sverjensky DA (1997) Inorganic species in geologic fluids: correlations among standard molal thermodynamic properties of aqueous ions and hydroxide complexes. Geochim Cosmochim Acta 61:907-950

Sillitoe RH, Hannington MD, Thompson JFH (1996) High sulfidation deposits in the volcanogenic massive sulfide environment. Econ Geol 91:204-212

Simmons SF, Brown KL (2006) Gold in magmatic hydrothermal solutions and the rapid formation of a giant ore deposit. Science 314: 288-291

Simmons SF, Brown KL, Tutolo BM (2016) Hydrothermal transport of $\mathrm{Ag}, \mathrm{Au}, \mathrm{Cu}, \mathrm{Pb}, \mathrm{Te}, \mathrm{Zn}$, and other metals and metalloids in New Zealand geothermal systems: spatial patterns, fluid-mineral equilibria, and implications for epithermal mineralization. Econ Geol 111: $589-618$

Sisson TW (2003) Native gold in a Hawaiian alkalic magma. Econ Geol 98:643-648

Spiess FN, Macdonald KC, Atwater T, Ballard R, Carranzy A, Cordoba D, Cox C, Diaz Garcia VM, Francheteau J, Guerro J, Hawkins J, Haymon R, Hessler R, Juteau T, Kastner M, Larson R, Macdougall JD, Miller S, Normark W, Orcutt J, Rangin C (1980) East Pacific rise: hot springs and geophysical experiments. Science 207:14211433

Spycher NF, Reed MH (1989) Evolution of a broadlands-type epithermal ore fluid along alternative P-T paths; implications for the transport and deposition of base, precious, and volatile metals. Econ Geol 84: 328-359

Stanton RL (1990) Magmatic evolution and the ore type-lava affiliations of volcanic exhalative ores. Aust Imm M 14:101-107

Stanton RL (1994) Ore elements in arc lavas. Oxford monographs on geology and geophysics. Clarendon, New York, p 404

Sverjensky DA, Shock EL, Helgeson HC (1997) Prediction of the thermodynamic properties of aqueous metal complexes to $1000^{\circ} \mathrm{C}$ and 5 kb. Geochim Cosmochim Acta 61:1359-1412

Taylor SR, McLennan SM (1985) The continental crust: its composition and evolution. Blackwell Scientific Publications, Oxford, p 312 
Törmänen TO, Koski RA (2005) Gold enrichment and the Bi-Au association in pyrrhotite-rich massive sulfide deposits, Escanaba Trough, Southern Gorda Ridge. Econ Geol 100:1135-1150

Tsunogai U, Ishibashi J, Wakita H, Gamo T, Watanabe K, Kajimura T, Kanayama S, Sakai H (1994) Peculiar features of Suiyo Seamount hydrothermal fluids, Izu-Bonin arc: differences from subaerial volcanism. Earth Planet Sc Lett 126:289-301

Urabe T (1987) The effect of pressure on the partitioning ratios of lead and zinc between vapor and rhyolite melts. Econ Geol 82:10491052

Von Damm KL (1990) Seafloor hydrothermal activity: black smoker chemistry and chimneys. Annu Rev Earth P1 Sc 18:173-204

Von Damm KL, Parker CM, Lilley MD, Clague DA, Zierenberg RA, Olson EJ, McClain JS (2006) Chemistry of vent fluids and its implications for subsurface conditions at Sea Cliff hydrothermal field, Gorda Ridge. Geochem Geophys Geosyst 7:1-18

Wang Y, Han X, Petersen S, Frische M, Qiu Z, Li H, Li H, Wu Z, Cui R (2017) Mineralogy and trace element geochemistry of sulfide minerals from the Wocan Hydrothermal Field on the slow-spreading Carlsberg Ridge, Indian Ocean. Ore Geol Rev 84:1-19

Watanabe K, Kajimura T (1994) The hydrothermal mineralization at Suiyo Seamount, in the central part of the Izu-Ogasawara arc. Resour Geol 44:133-140

Webber AP, Roberts S, Taylor RN, Pitcairn IK (2013) Golden plumes: substantial gold enrichment of oceanic crust during ridge-plume interaction. Geology 41:87-90

Webber AP, Roberts S, Murton BJ, Mills RA, Hodgkinson MRS (2017) The formation of gold-rich seafloor sulfide deposits: evidence from the Beebe hydrothermal vent field, Cayman Trough. Geochem Geophys Geosyst 18:1-17

Wetzel LR, Shock EL (2000) Distinguishing ultramafic-from basalthosted submarine hydrothermal systems by comparing calculated vent fluid compositions. J Geophys Res Solid Earth 105:8319-8340
Wohlgemuth-Ueberwasser CC, Viljoen F, Petersen S, Vorster C (2015) Distribution and solubility limits of trace elements in hydrothermal black smoker sulfides: an in-situ LA-ICP-MS study. Geochim Cosmochim Acta 159:16-41

Wu Z, Sun X, Xu H, Konishi H, Wang Y, Wang C, Dai Y, Deng X, Yu M (2016) Occurrences and distribution of "invisible" precious metals in sulfide deposits from the Edmond hydrothermal field, Central Indian Ridge. Ore Geol Rev 79:105-132

Yang K, Scott SD (1996) Possible contribution of a metal-rich magmatic fluid to a sea-floor hydrothermal system. Nature 383:420-423

Yang K, Scott SD (2002) Magmatic degassing of volatiles and ore metals into a hydrothermal system on the modern sea floor of the eastern Manus back-arc basin, western Pacific. Econ Geol 97:1079-1100

Yang K, Scott SD (2006) Magmatic fluids as a source of metals in seafloor hydrothermal systems. In: Christie DM, Fisher RF, Lee SM, Givens S (eds) Back-arc spreading systems geological, biological, chemical, and physical interactions. American Geophysical Union, Washington, pp 163-184

Ye J, Shi X, Yang Y, Li N, Liu J, Su W (2012) The occurrence of gold in hydrothermal sulfide at Southwest Indian Ridge $49.6^{\circ} \mathrm{E}$. Acta Oceanol Sin 31:72-82

Zierenberg RA, Schiffman P (1990) Microbial control of silver mineralization at a sea-floor hydrothermal site on the northern Gorda Ridge. Nature 348:155-157

Zierenberg RA, Shanks WC III (1986) Isotopic constraints on the origin of the Atlantis II, Suakin and Valdivia brines, Red Sea. Geochim Cosmochim Acta 50:2205-2214

Publisher's note Springer Nature remains neutral with regard to jurisdictional claims in published maps and institutional affiliations. 